\title{
Interrupted Nazarov Reactions Using Dichlorocyclopropanes: A Novel Mode of Arene Trapping
}

Tina N. Grant and F. G. West*

Department of Chemistry, University of Alberta, Edmonton, AB, Canada T6G $2 G 2$

frederick.west@ualberta.ca

Supporting Information: Part 1-Experimental procedures and physical data for 5a-i, 1a-i, 4a-f, 2h, 6i, 8a-e, 10a, 11a, 12b-e and synthetic intermediates, as well as ORTEP structures for 6i, 12d and 12e (29 pages); Part 2-NMR spectra (99 pages) for 5a-i, 1a-i, 4a-f, 2h, 6i, 8a-e, 10a, 11a, 12b-e and synthetic intermediates.

Part 2: NMR spectra 


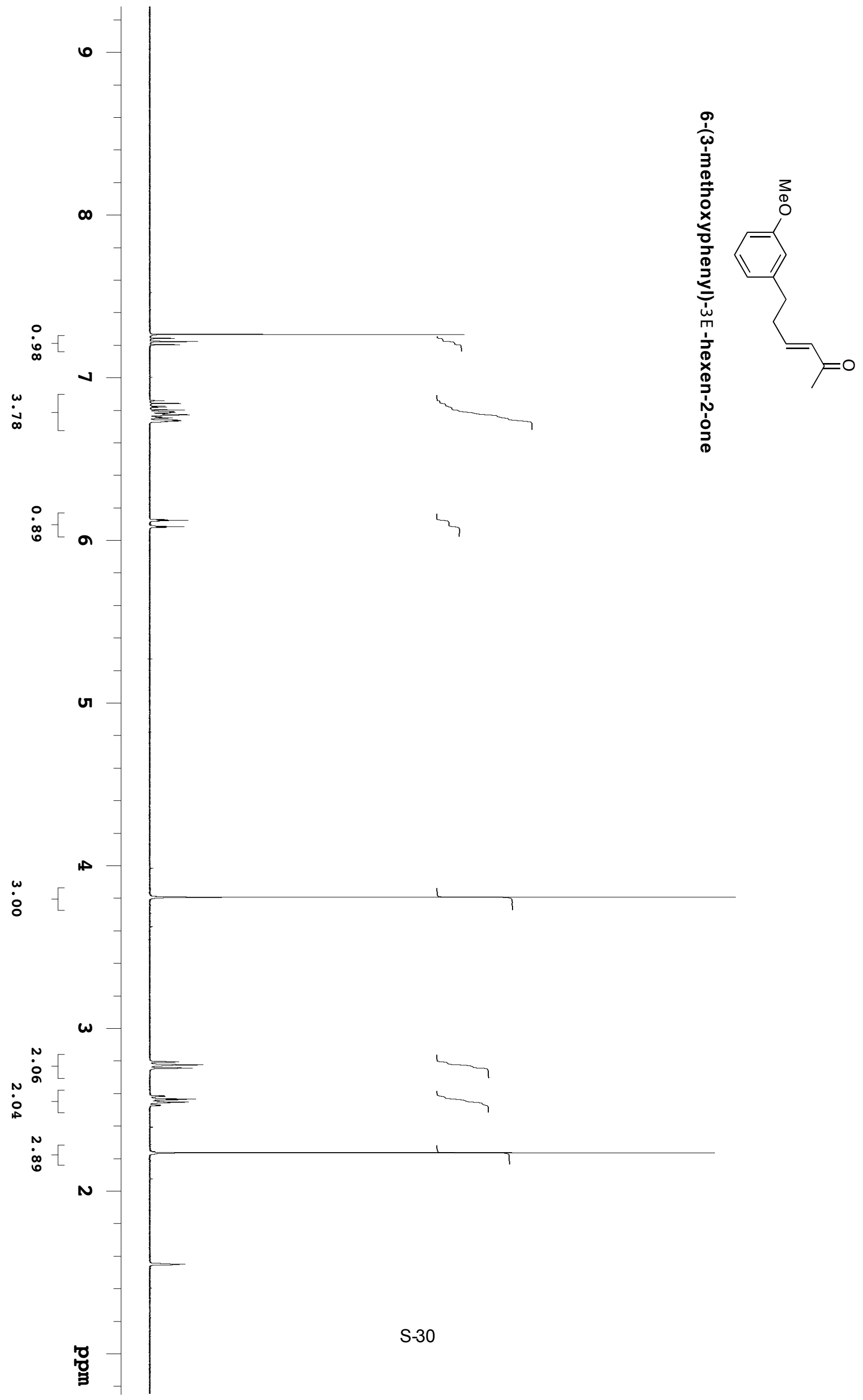




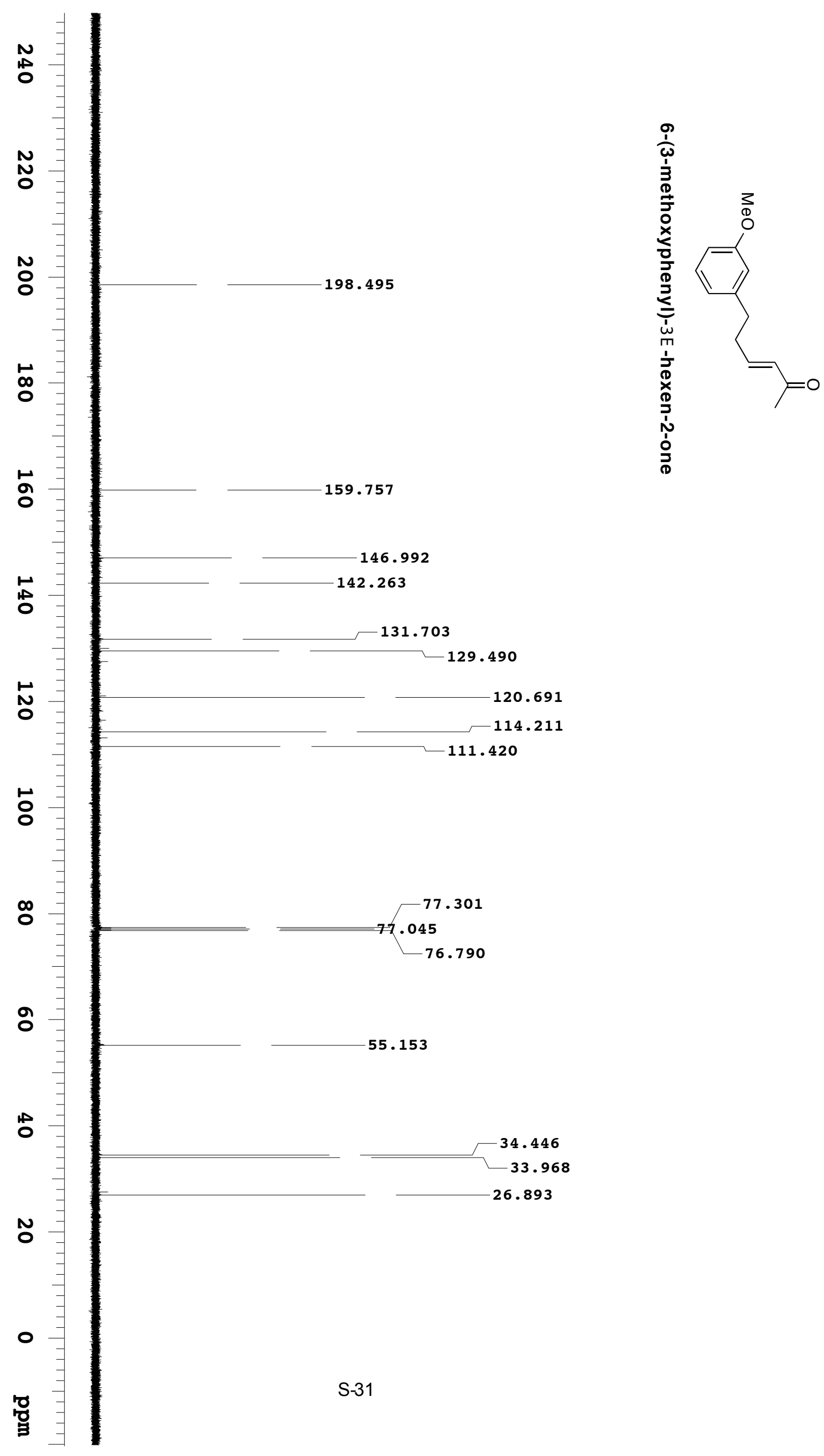




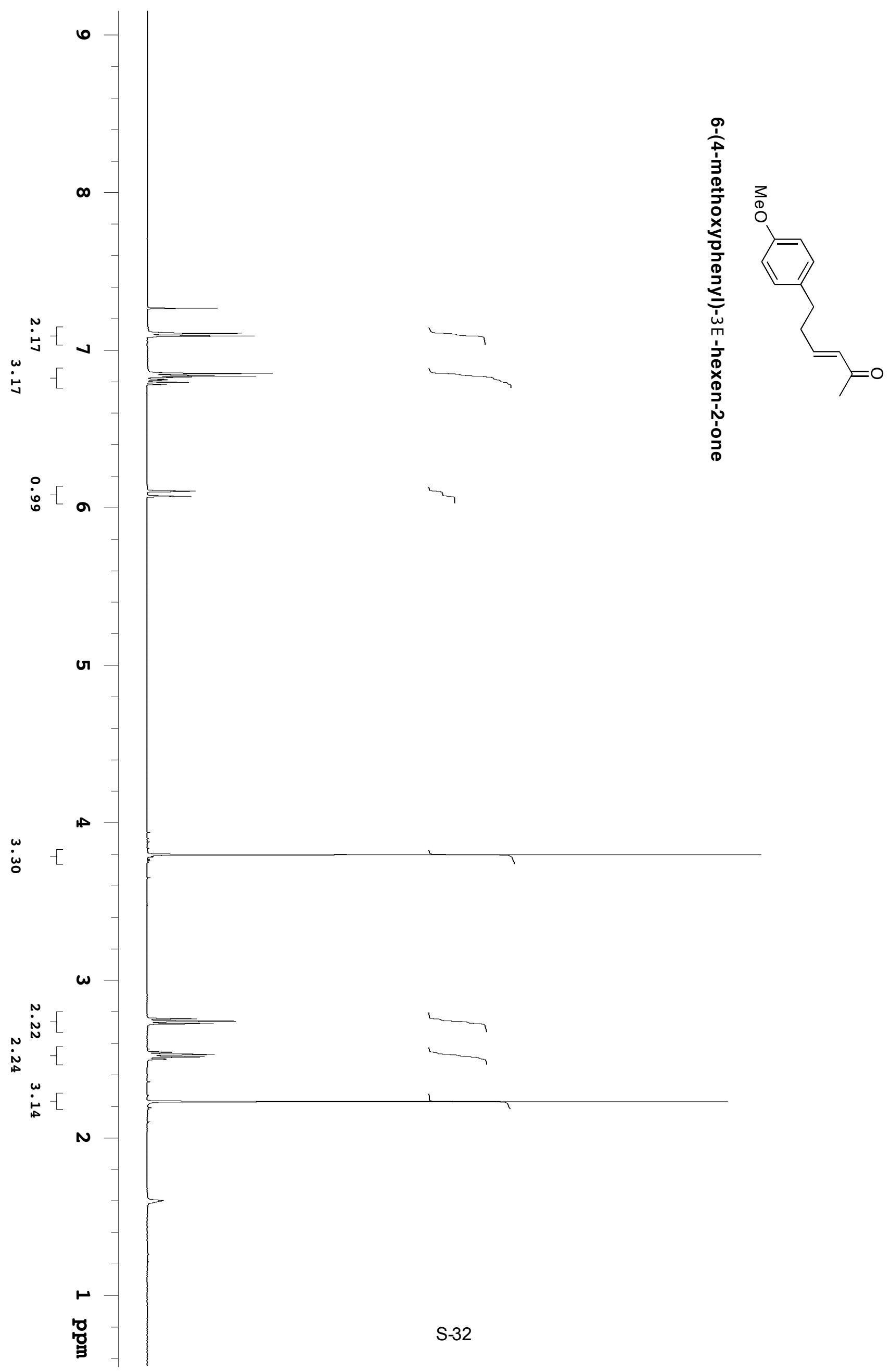




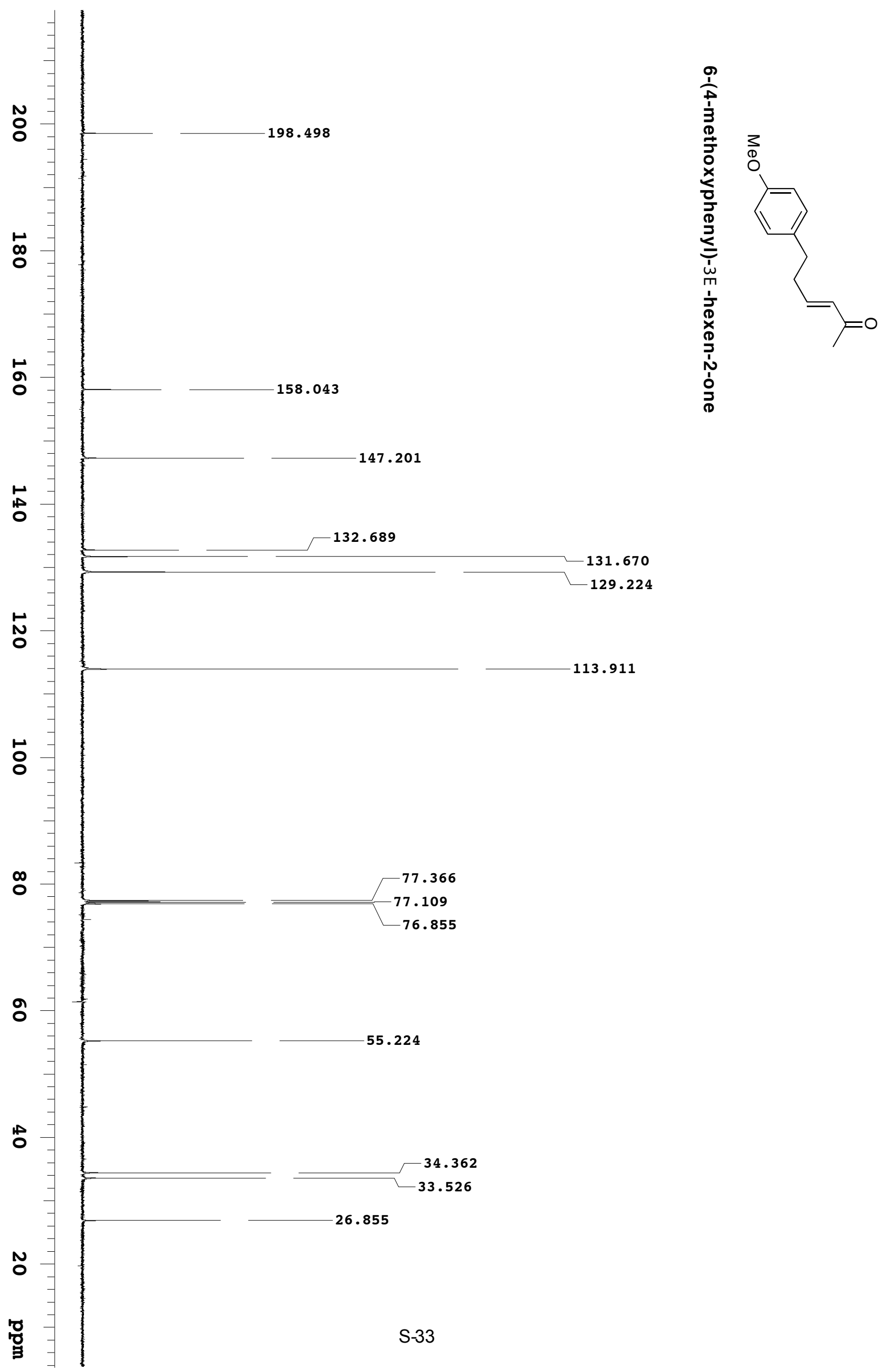




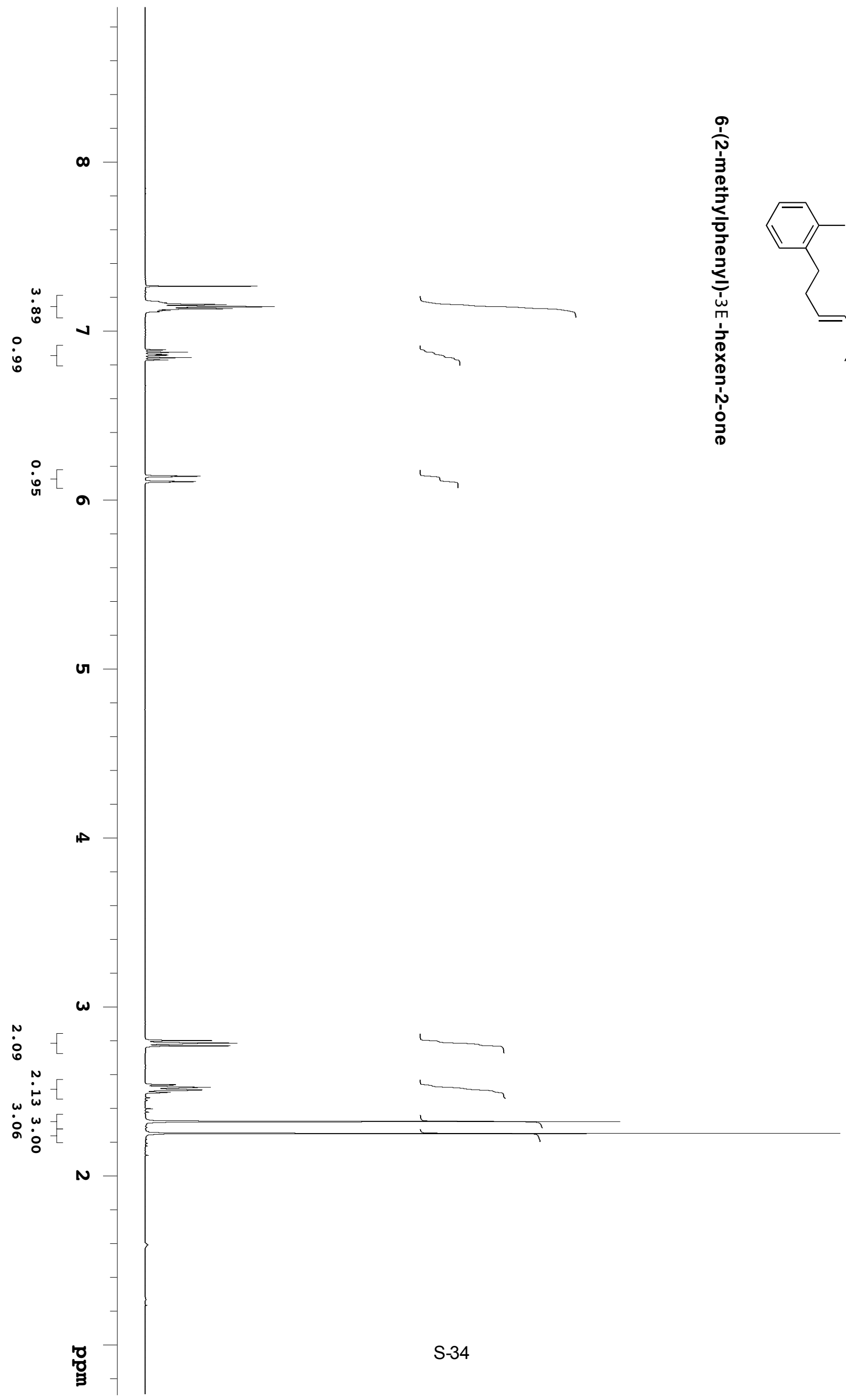



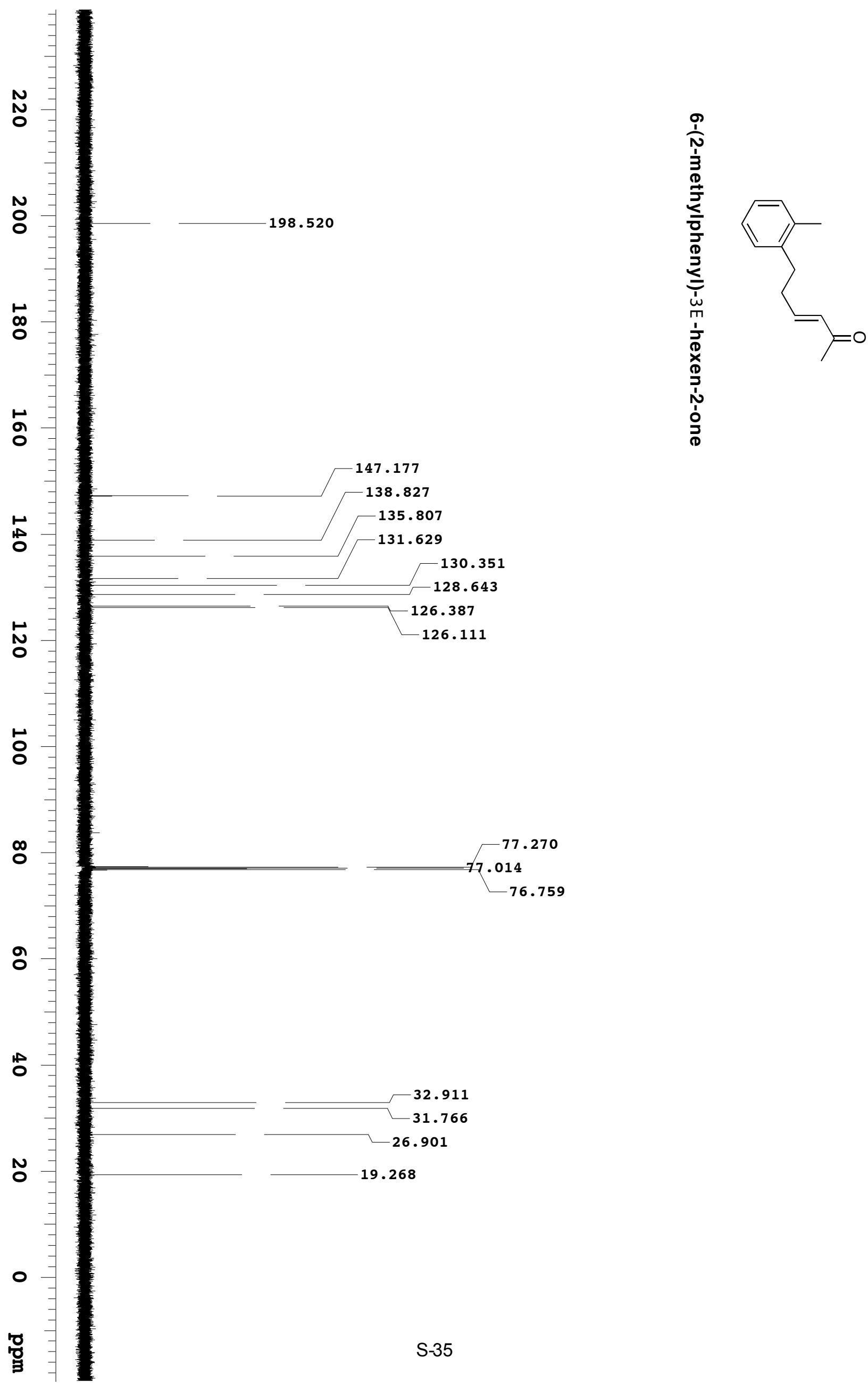


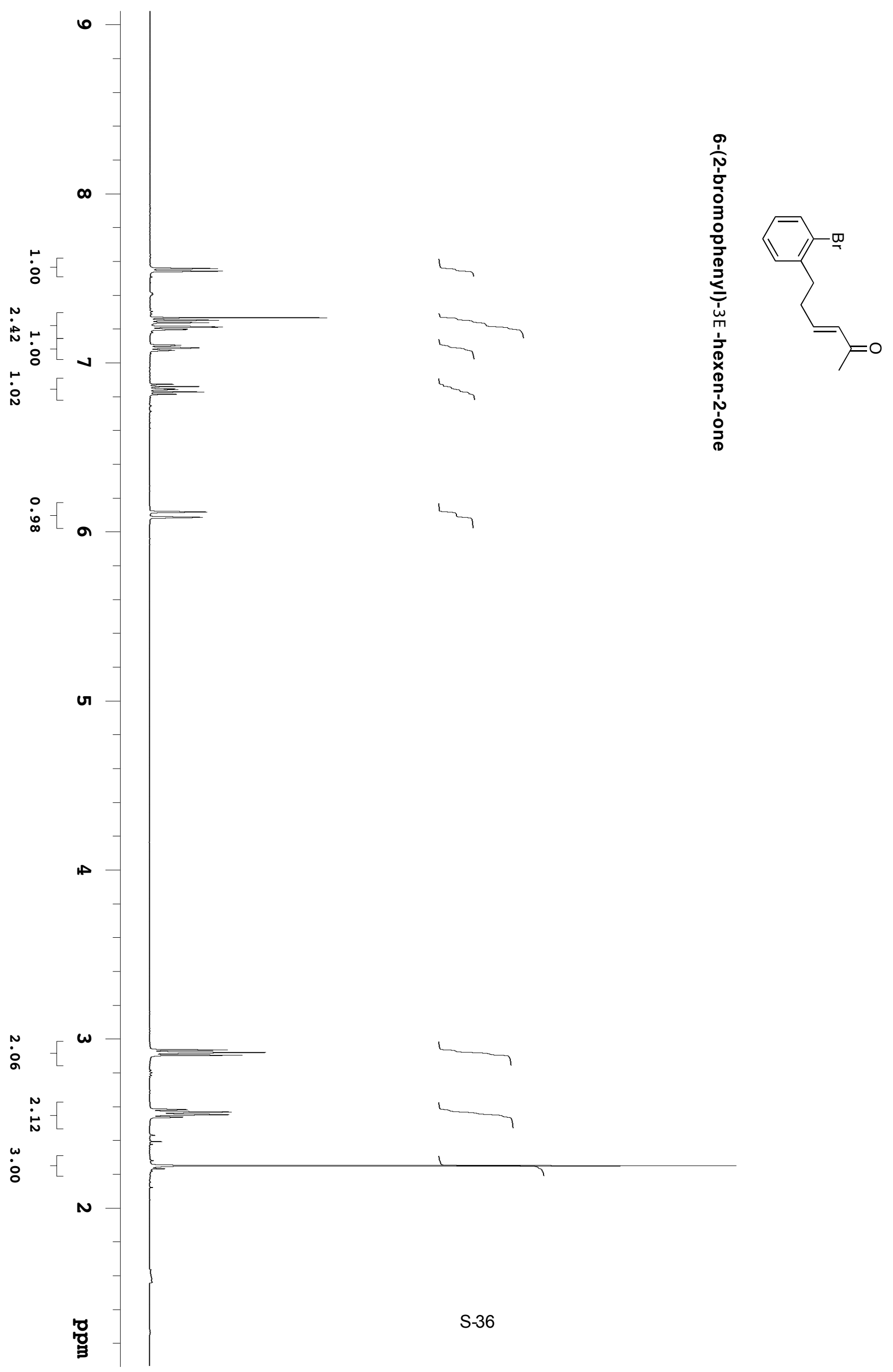




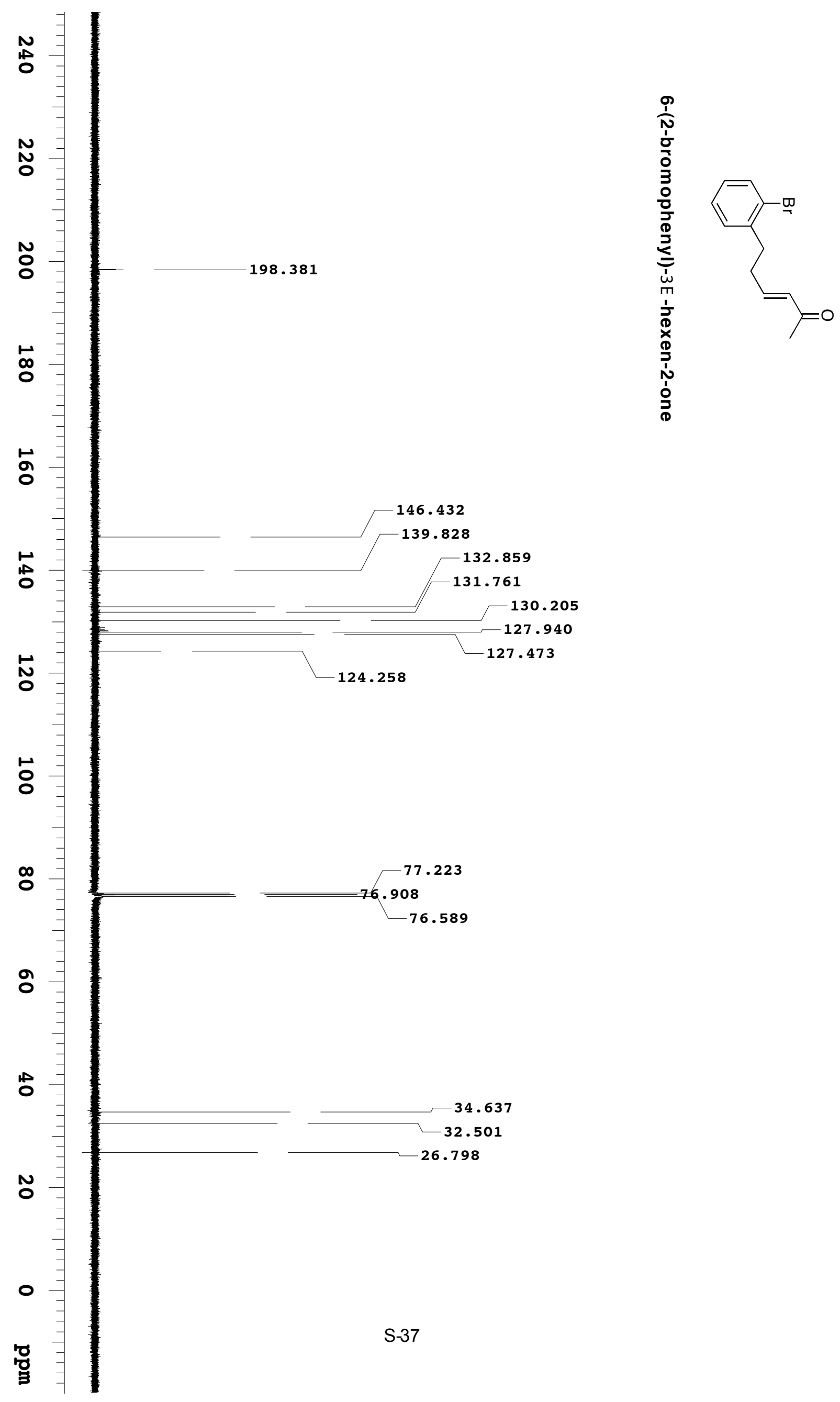




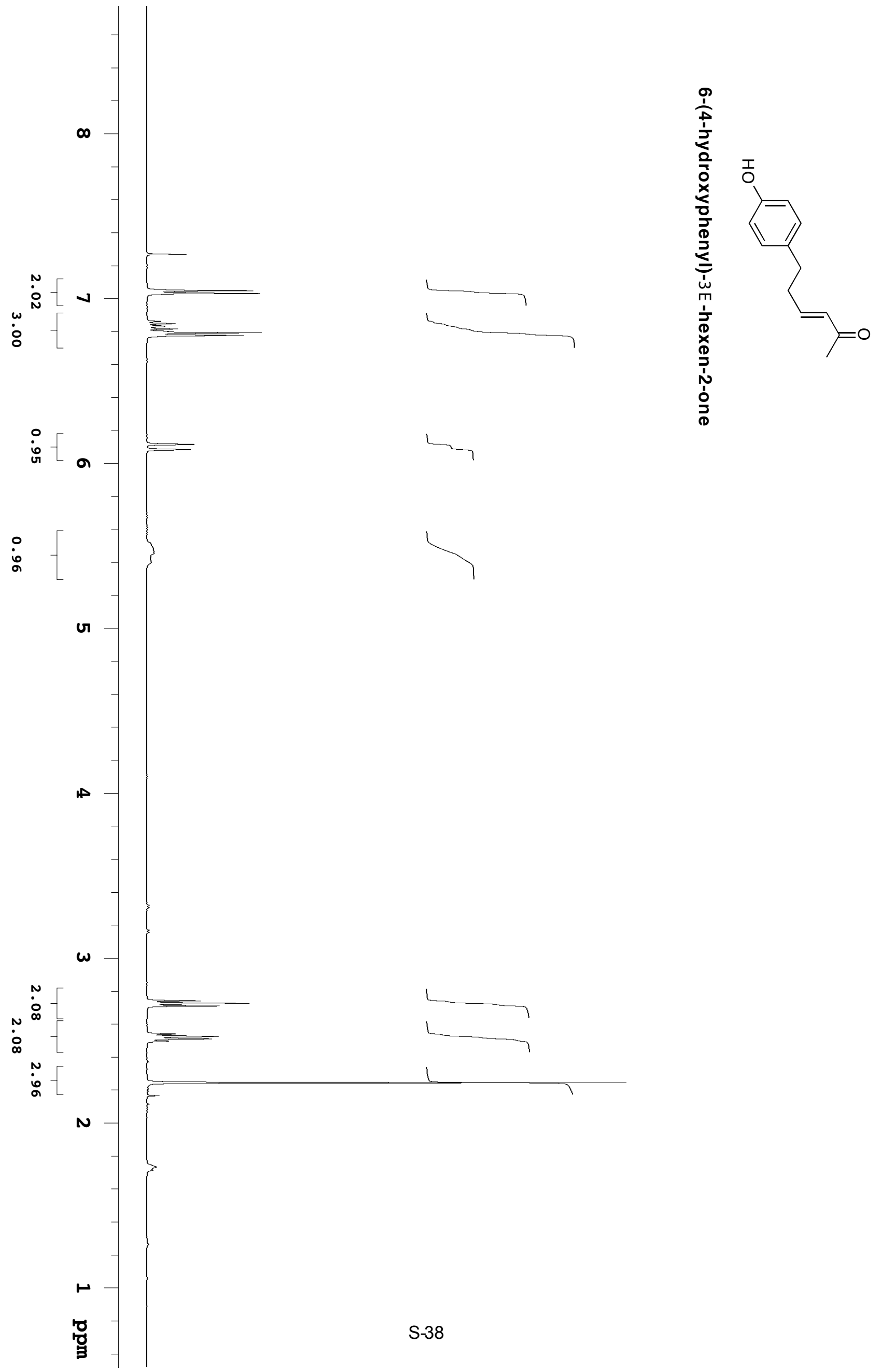




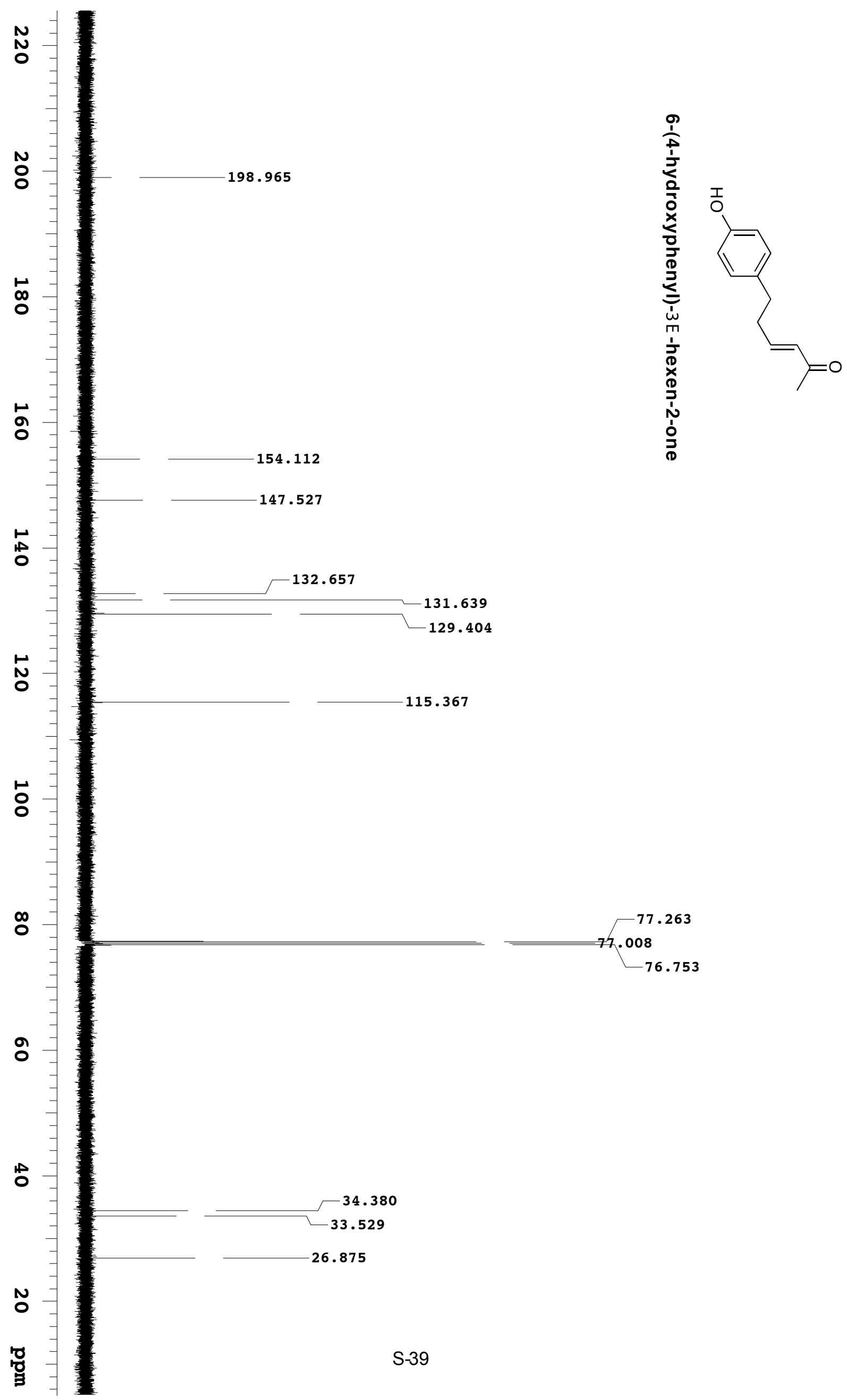




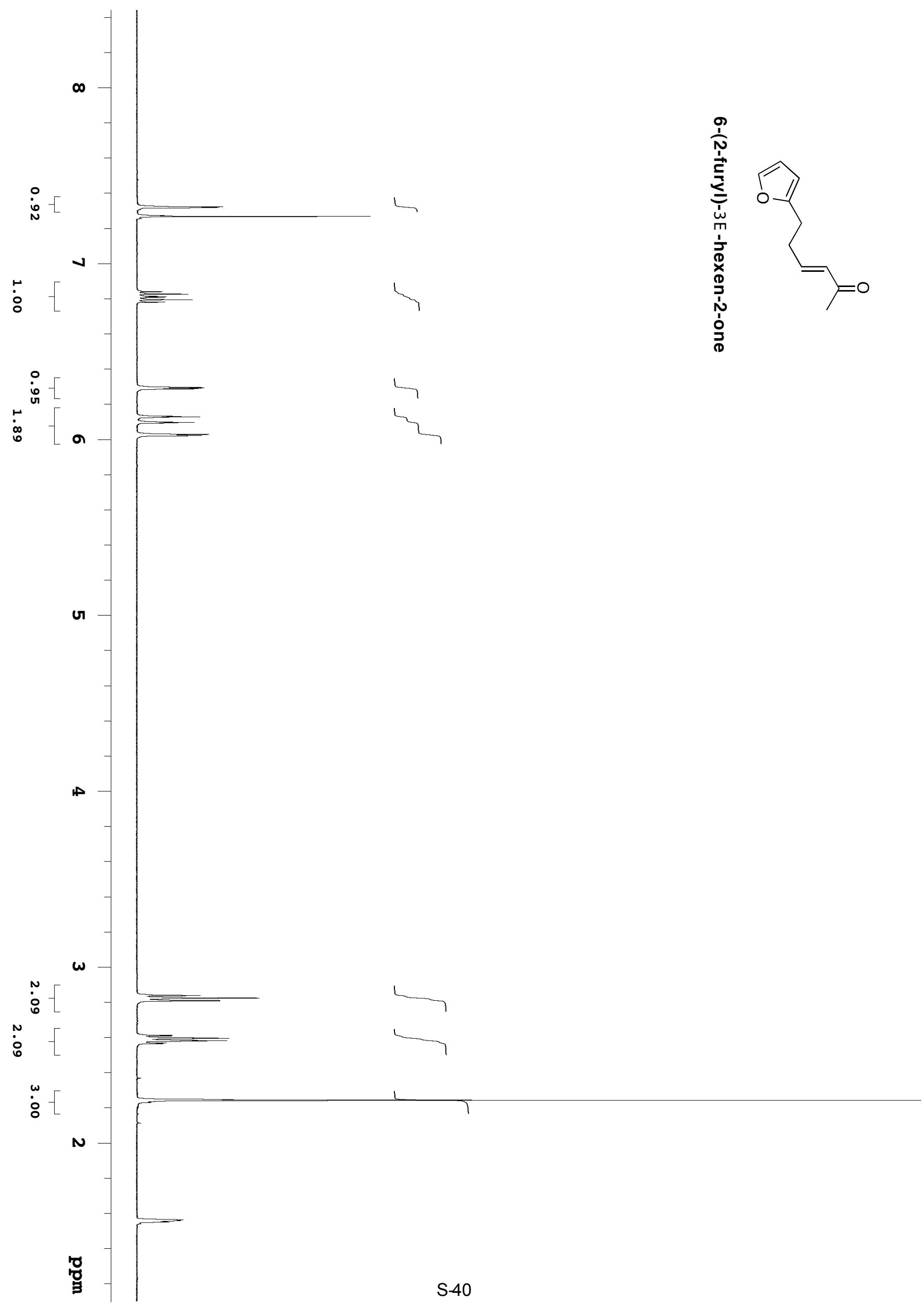



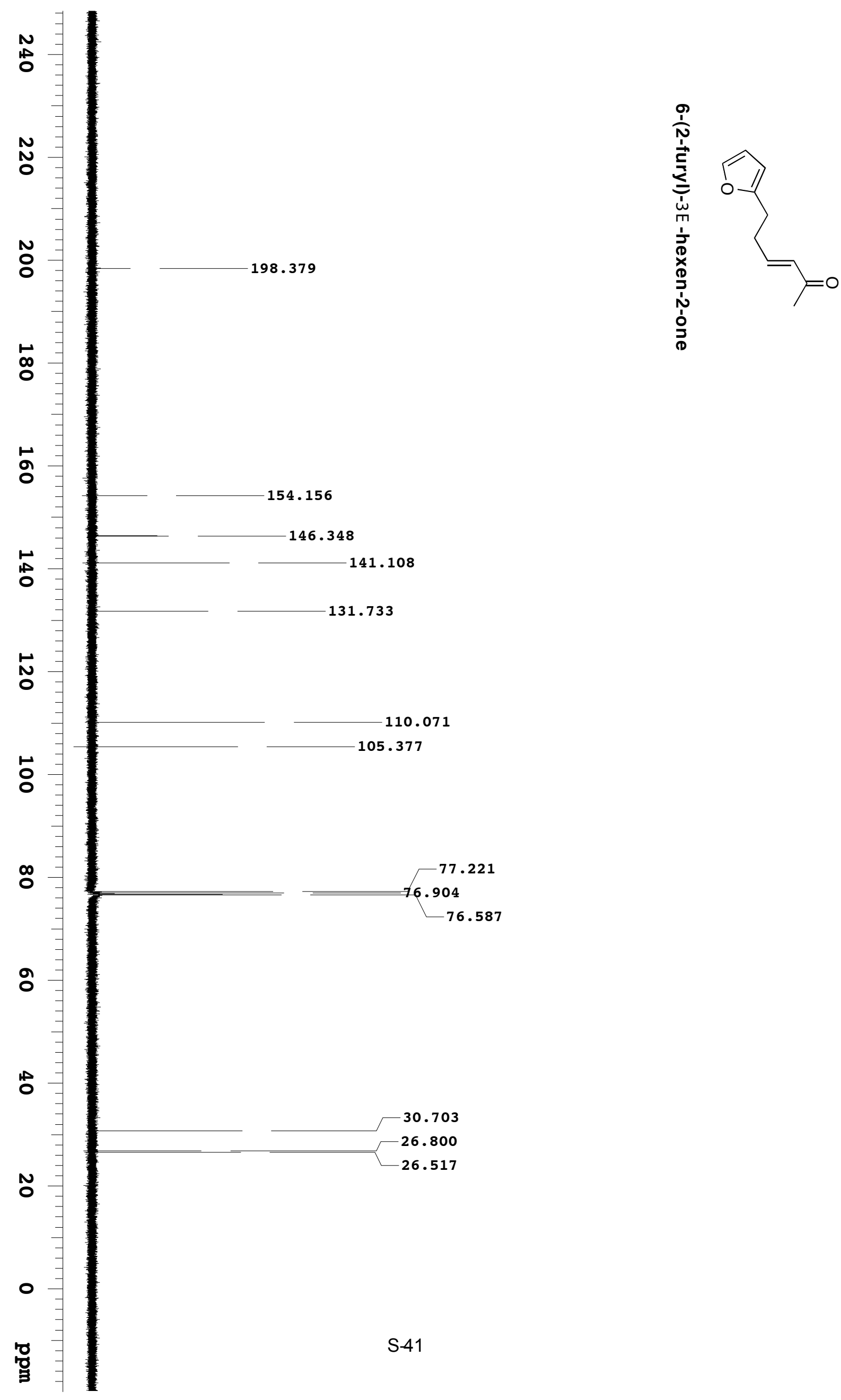


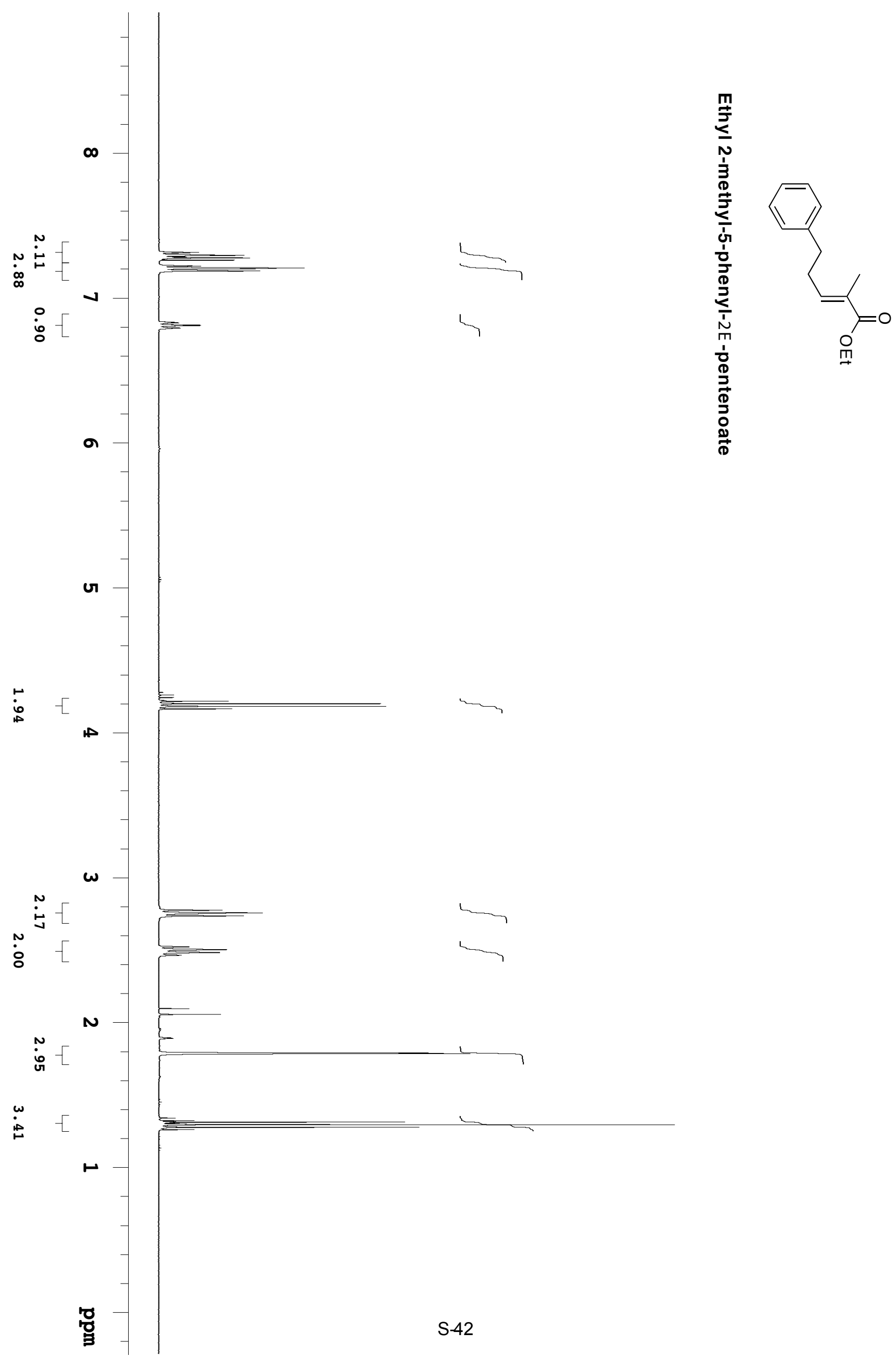




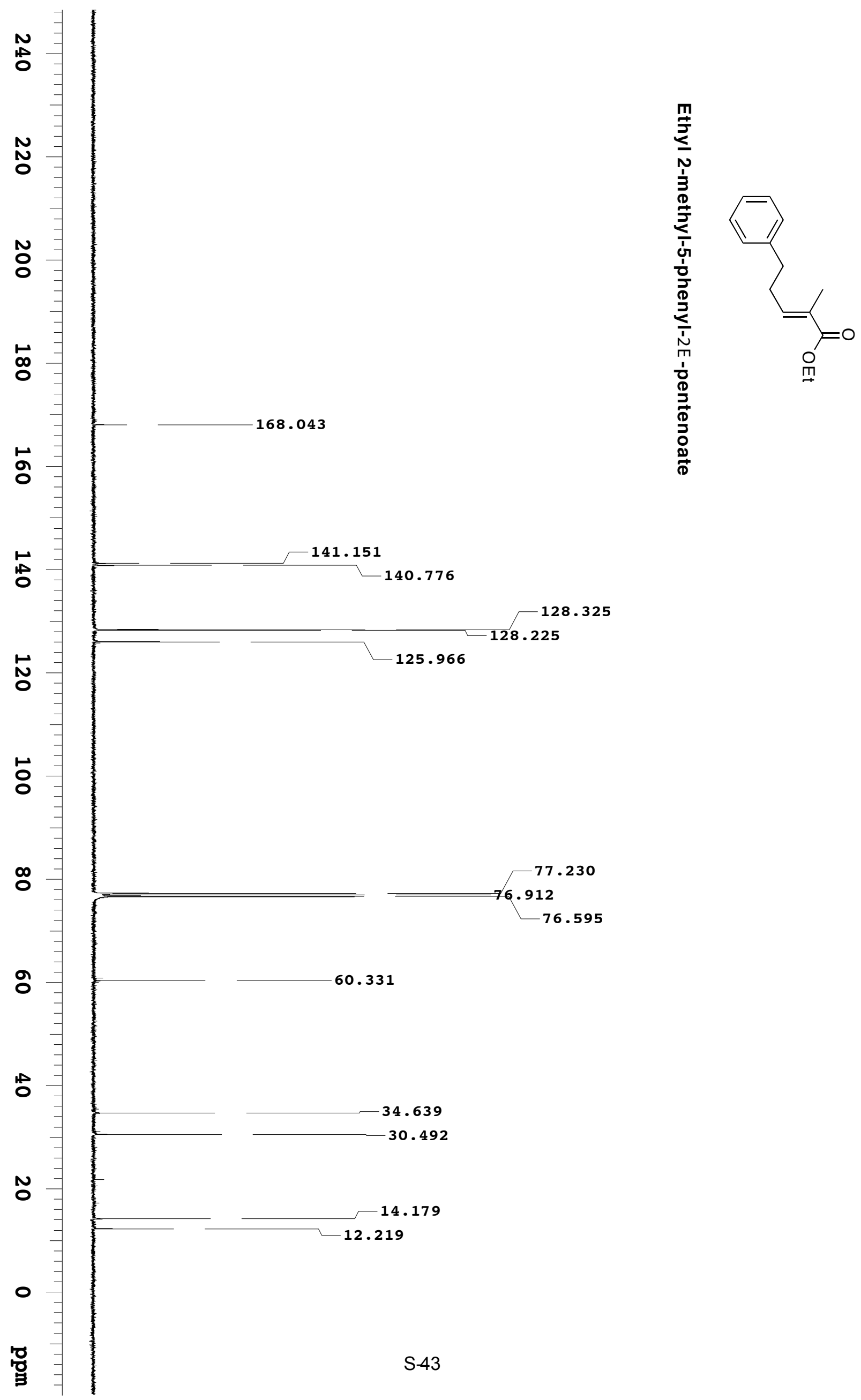




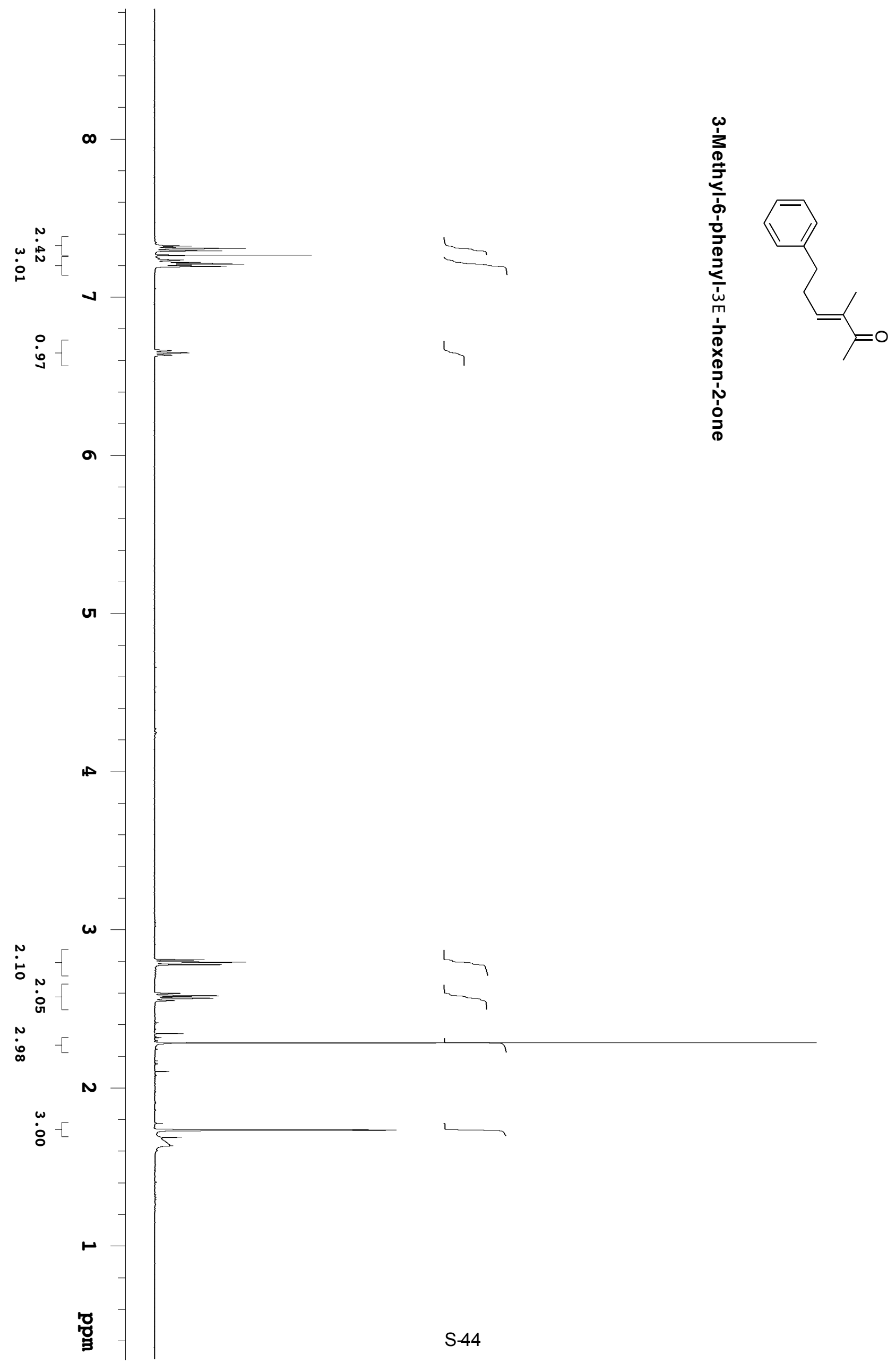




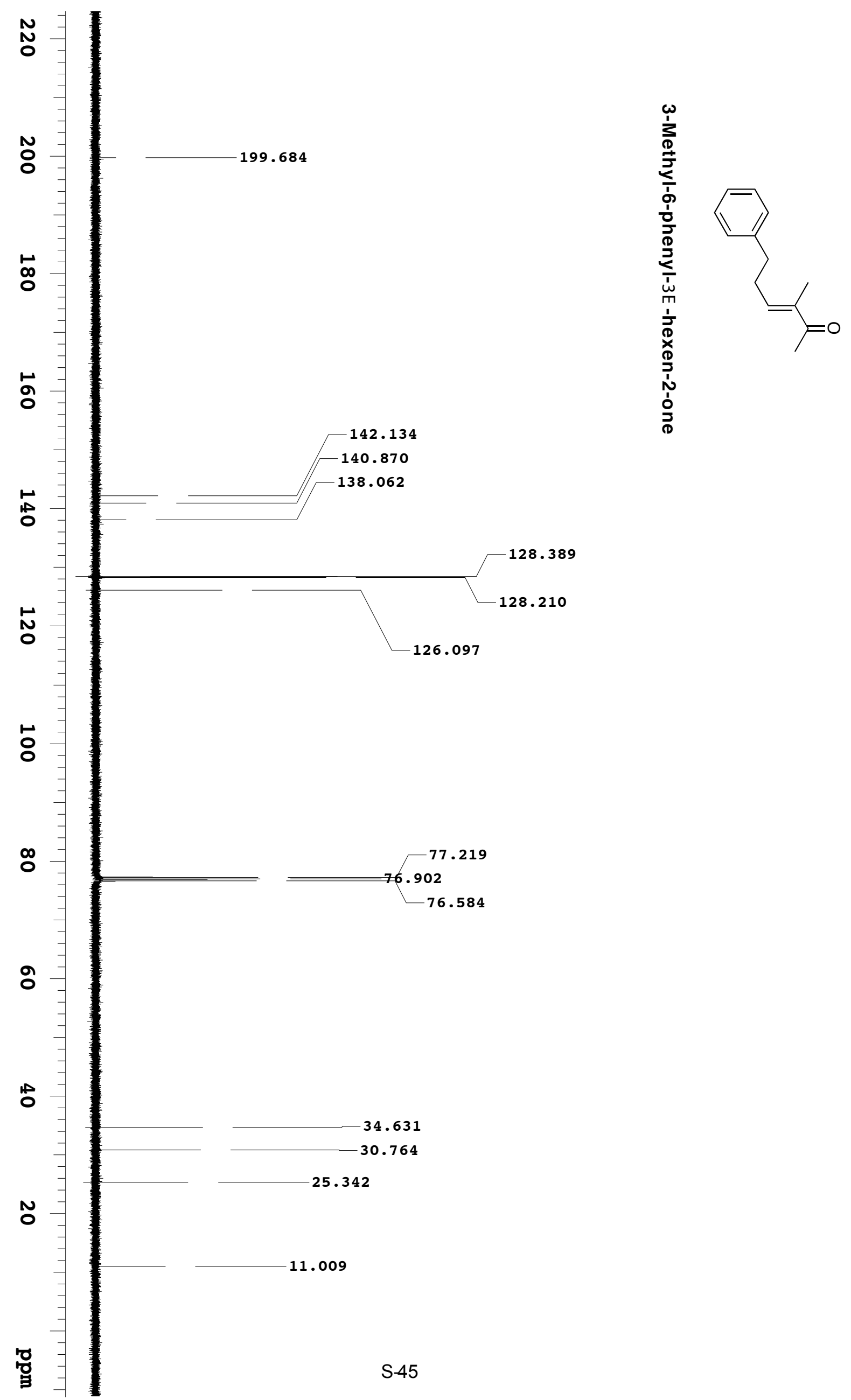




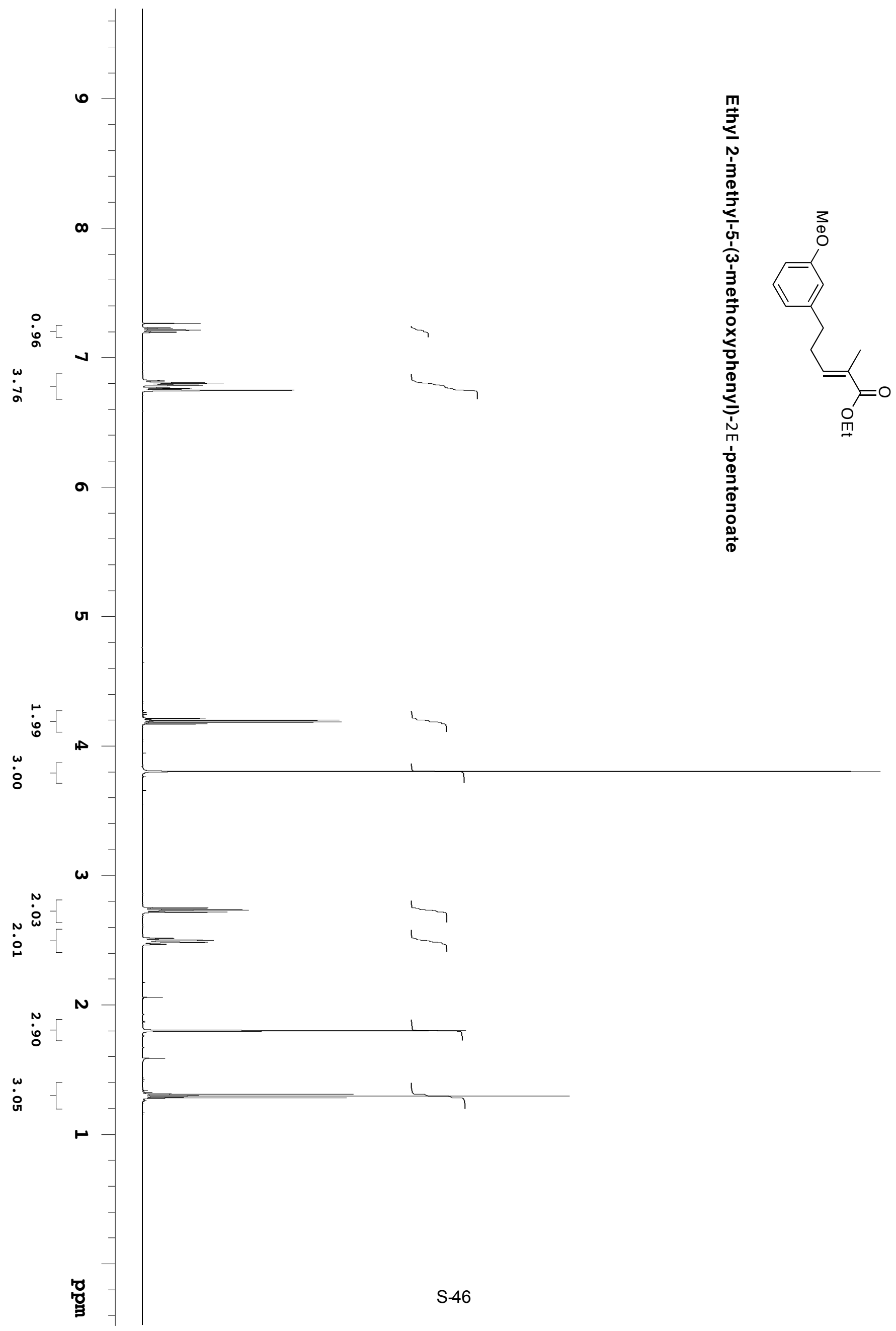




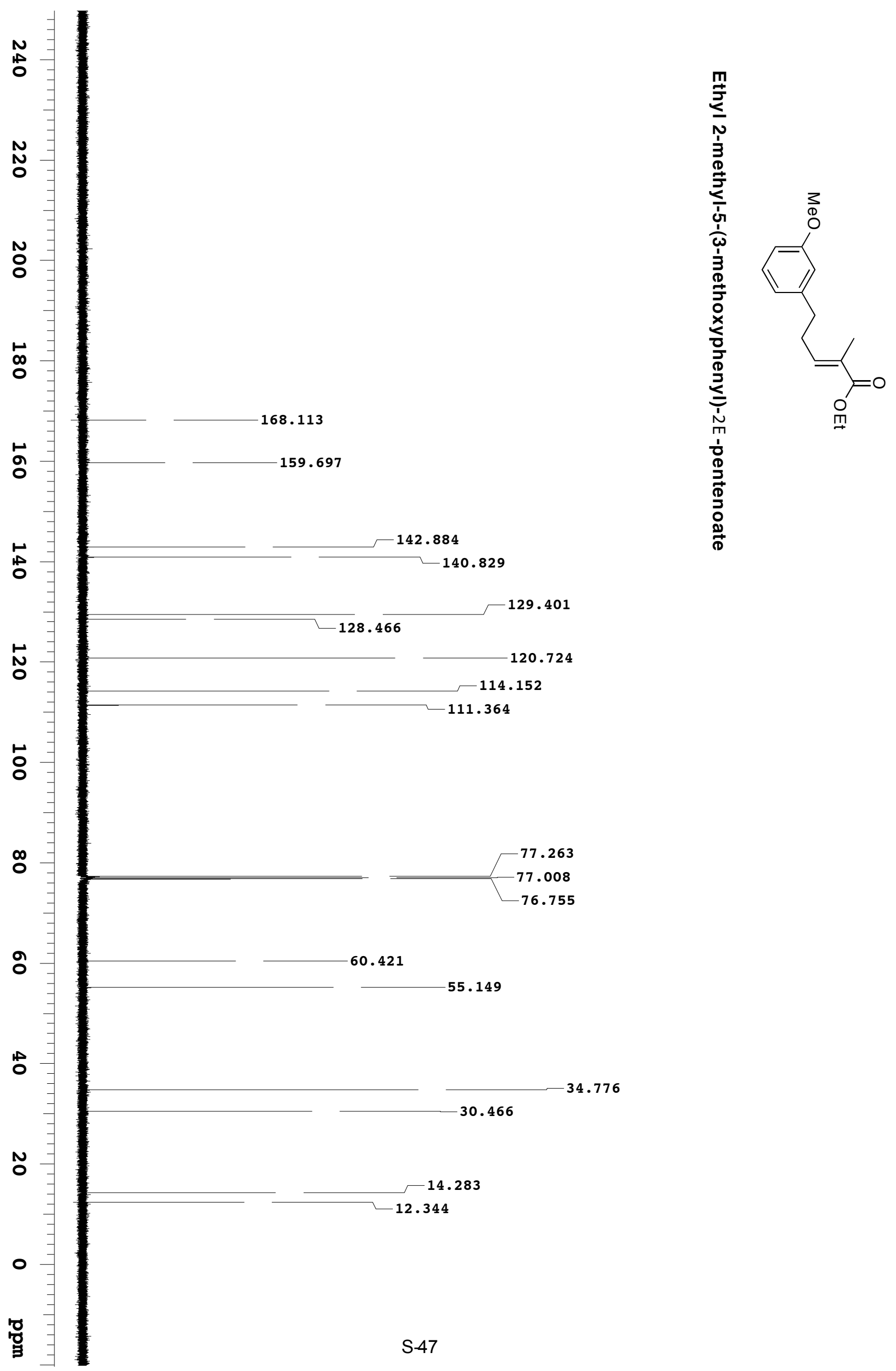




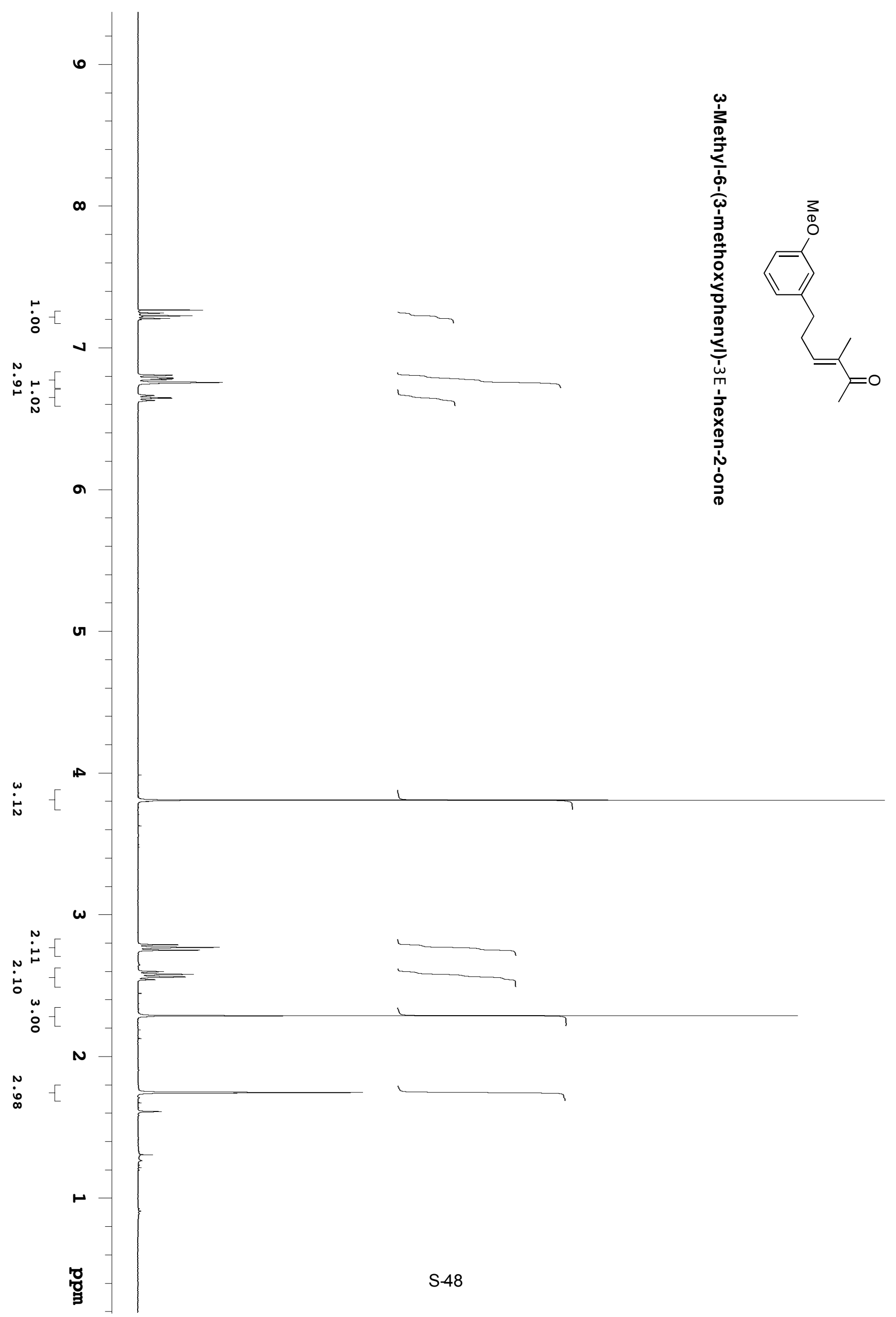




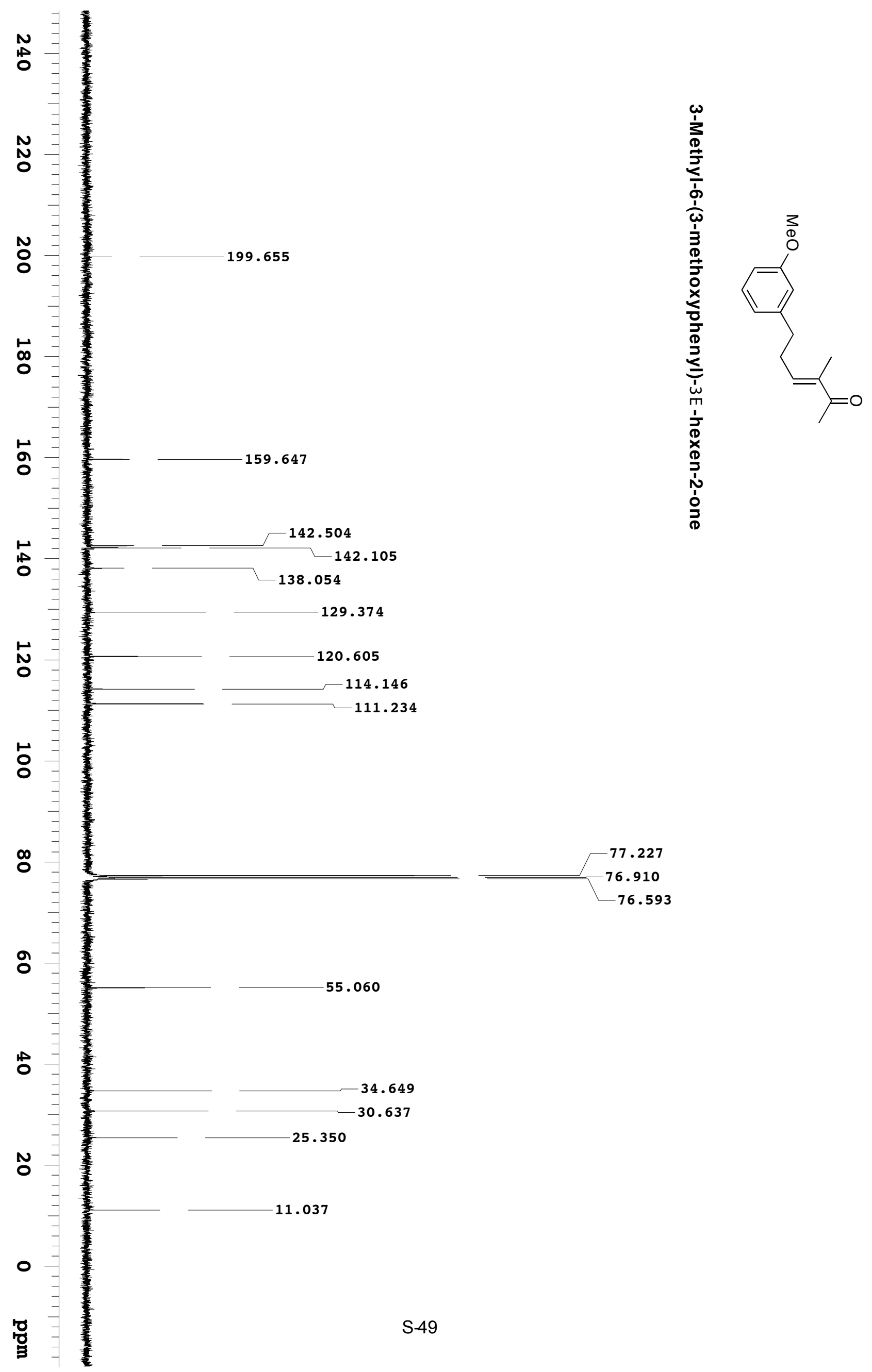




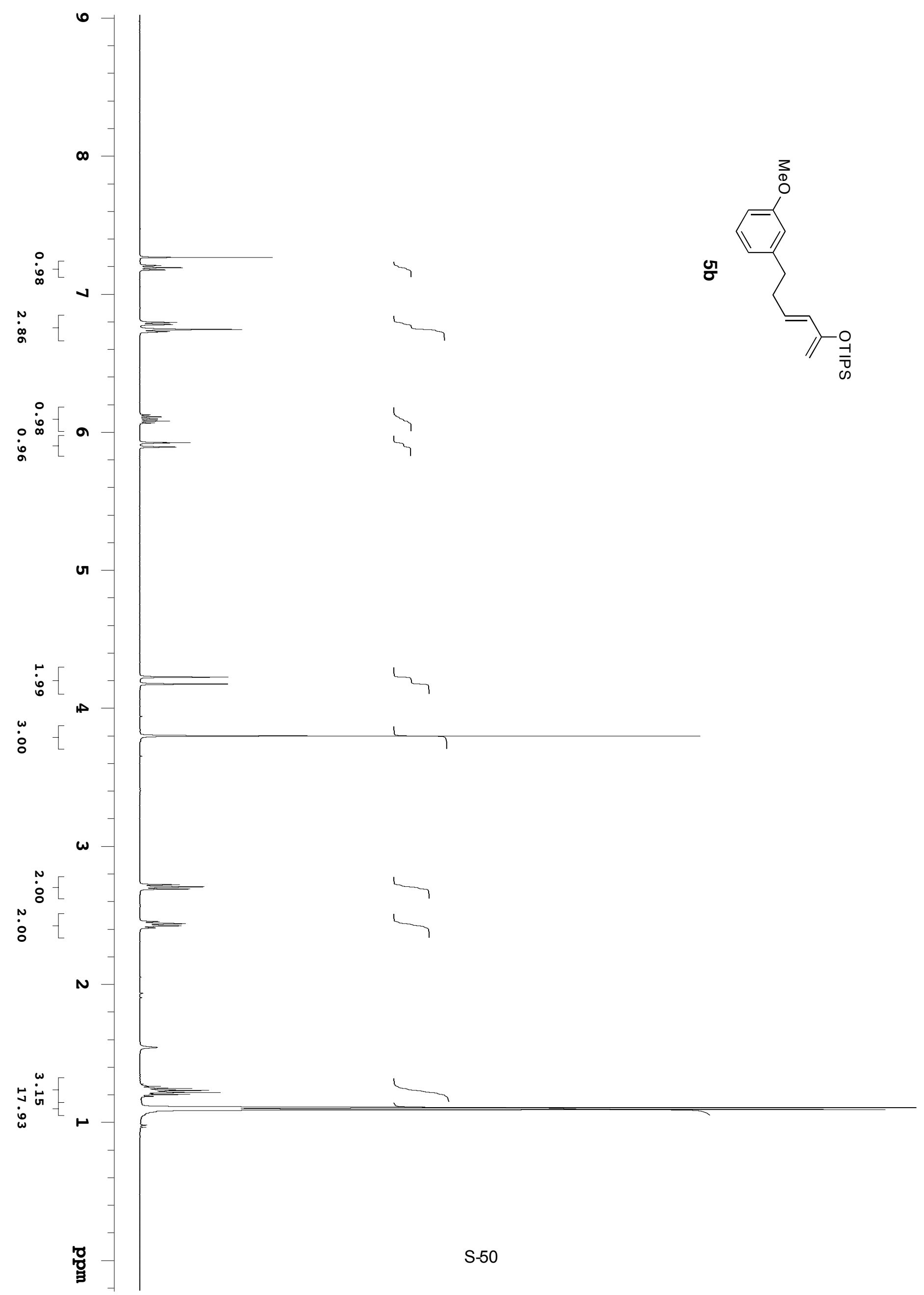




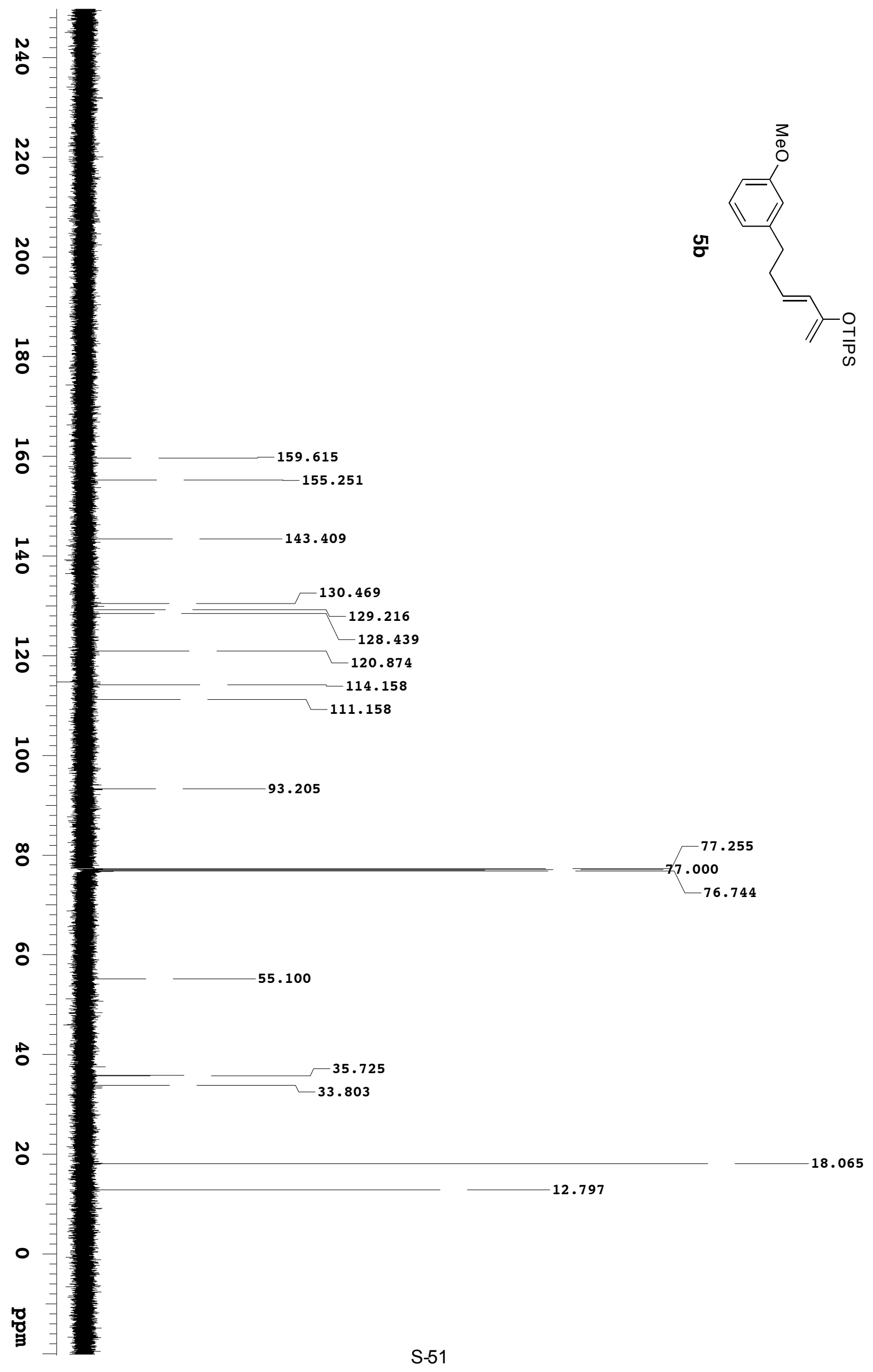




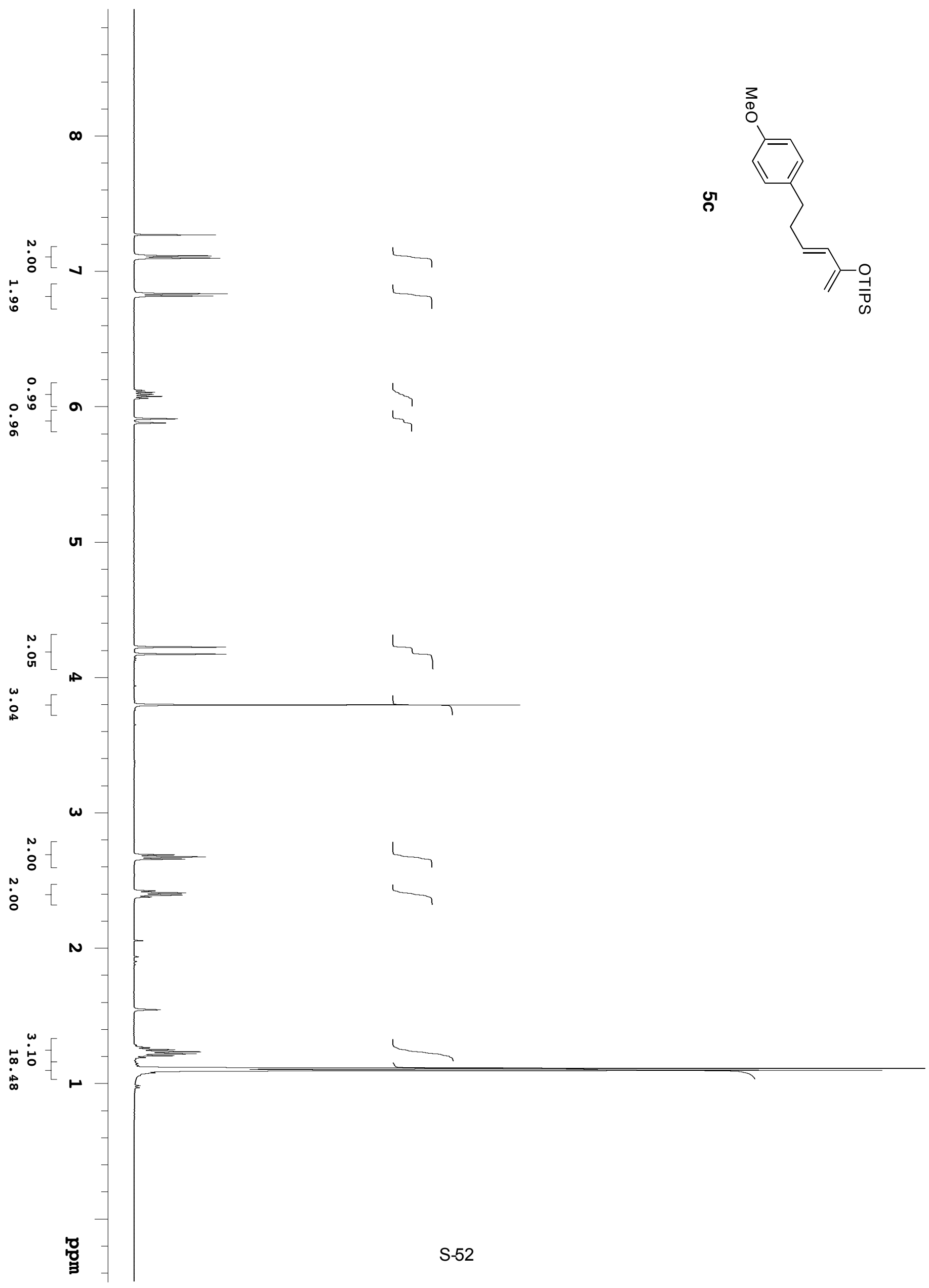




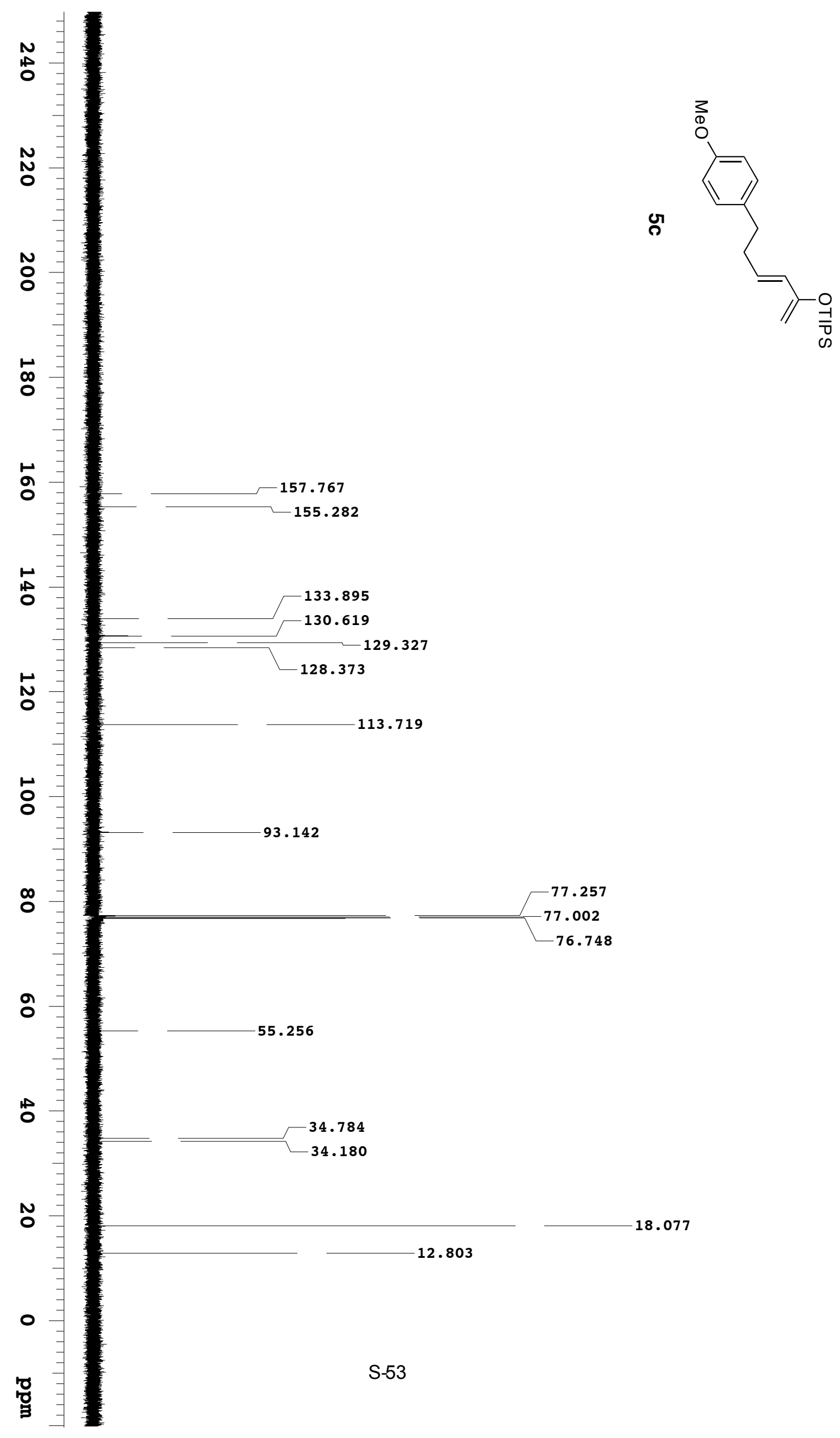




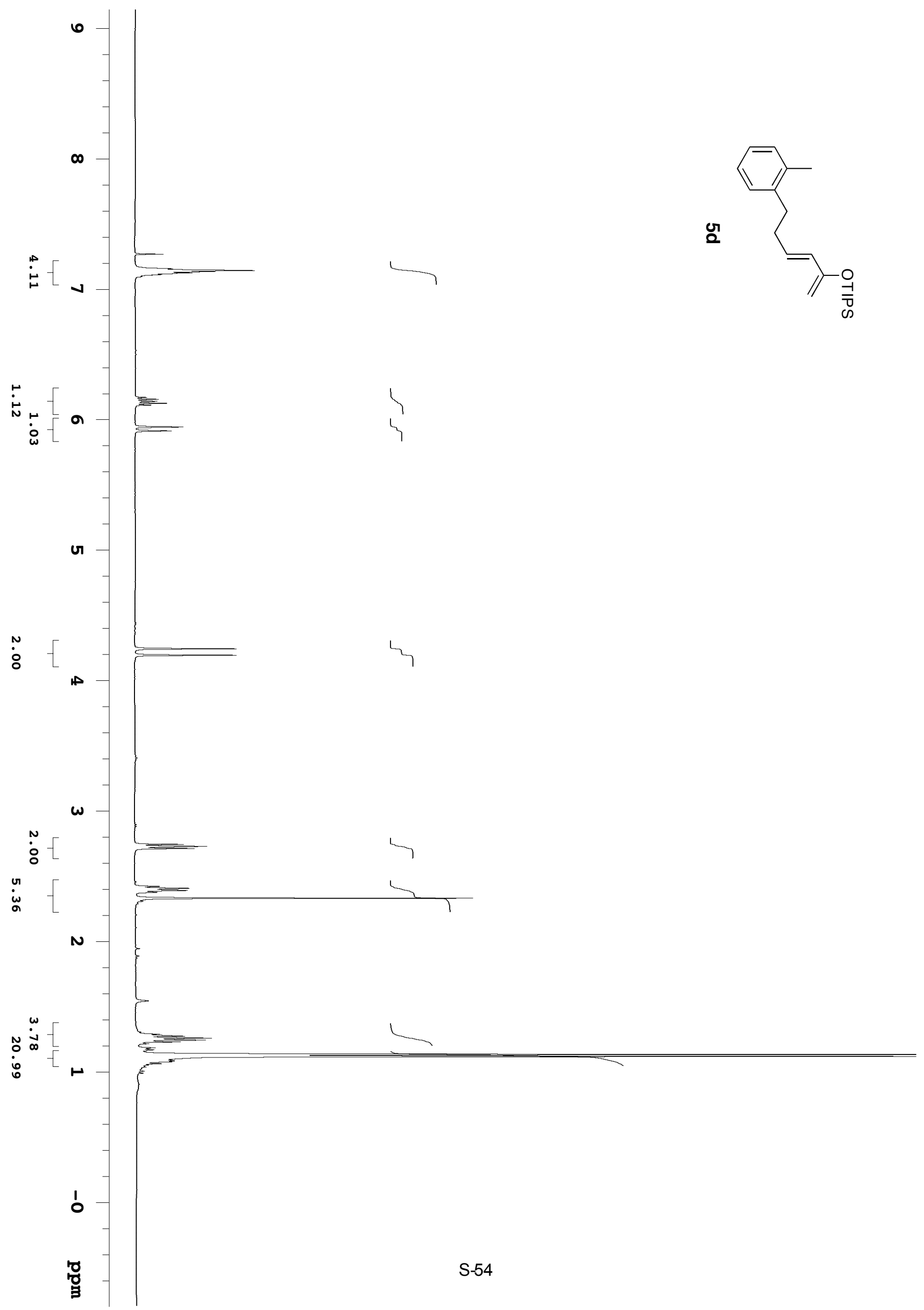




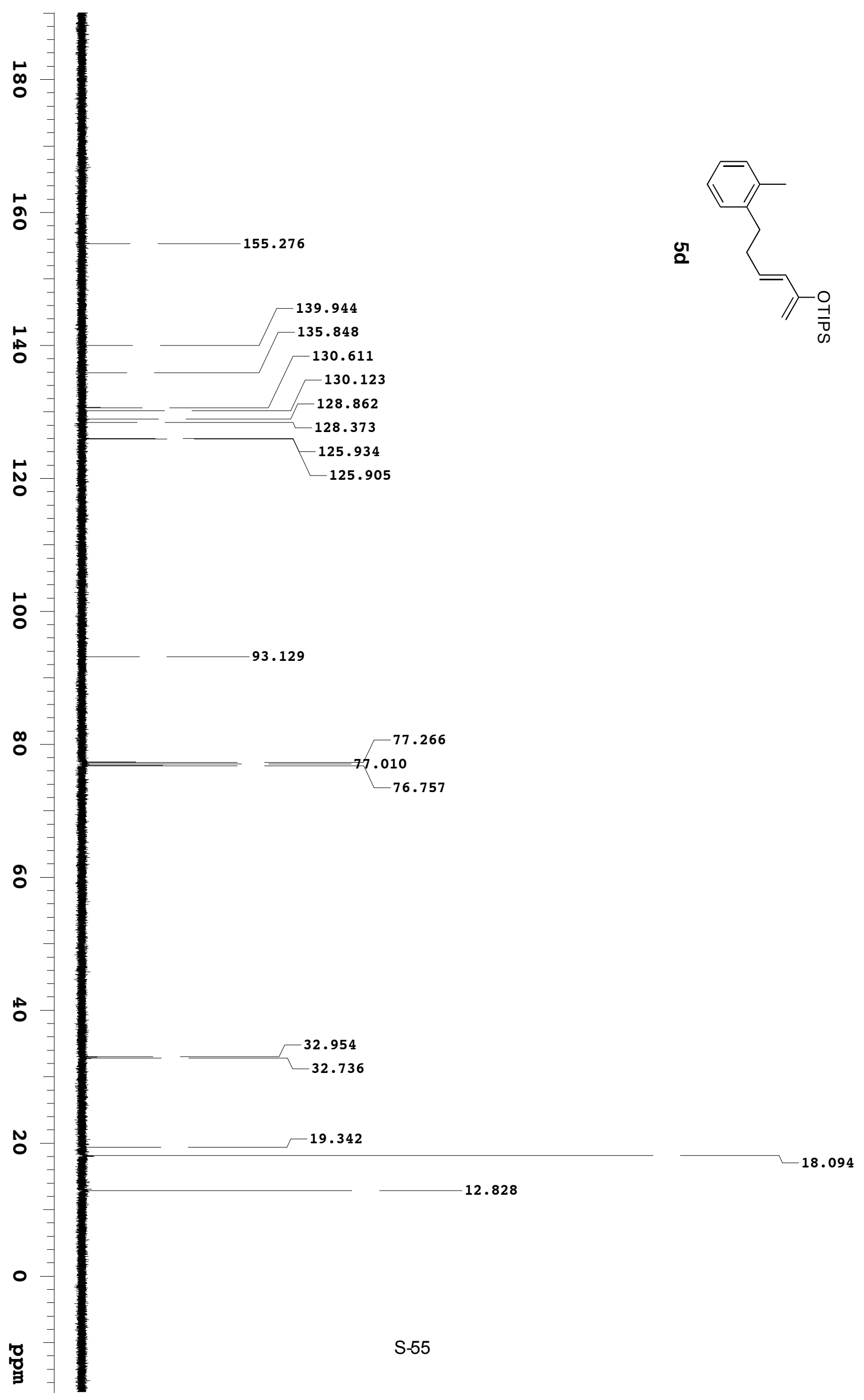




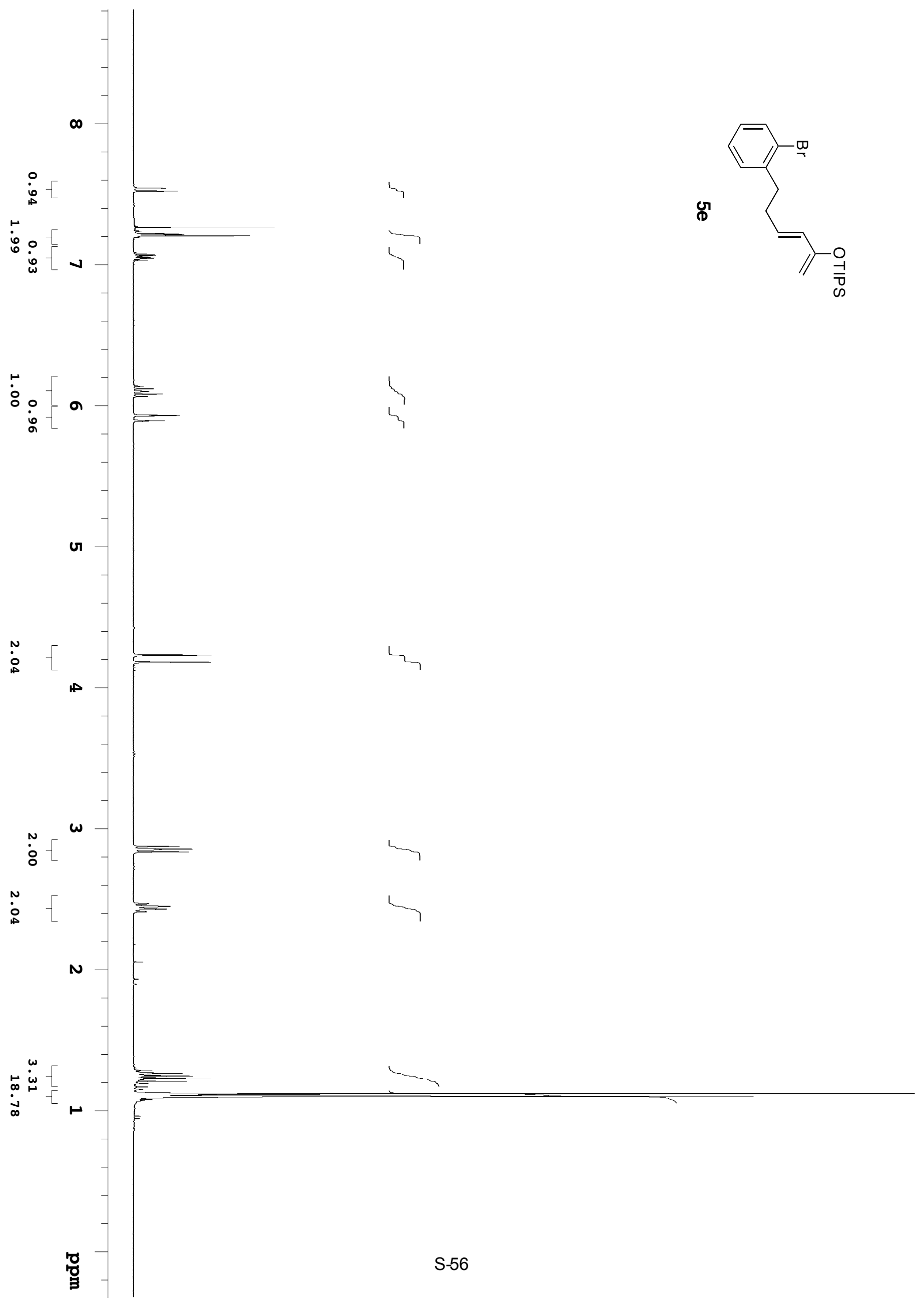



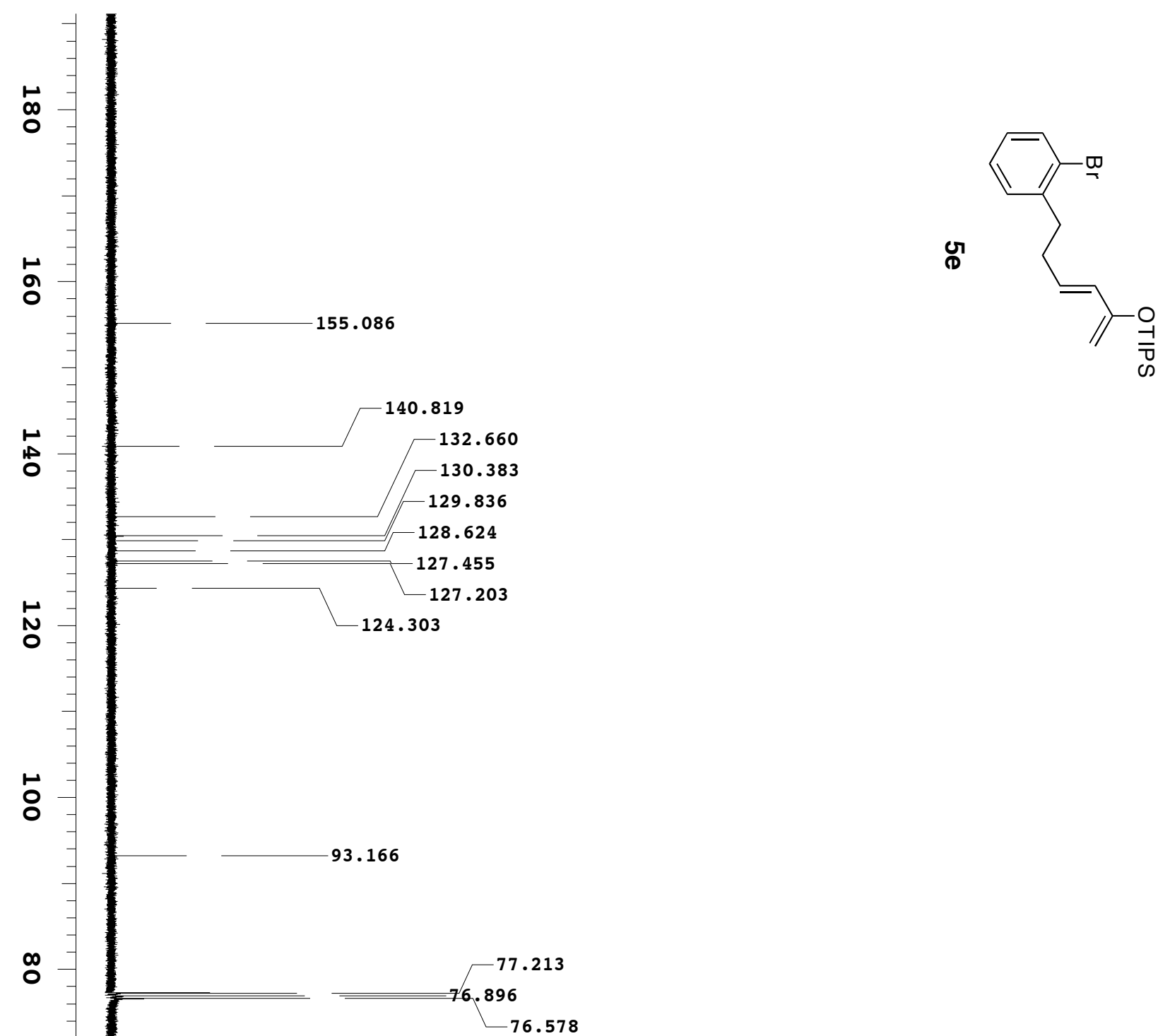

ㅇ

- $\quad 35.798$

$-32.038$
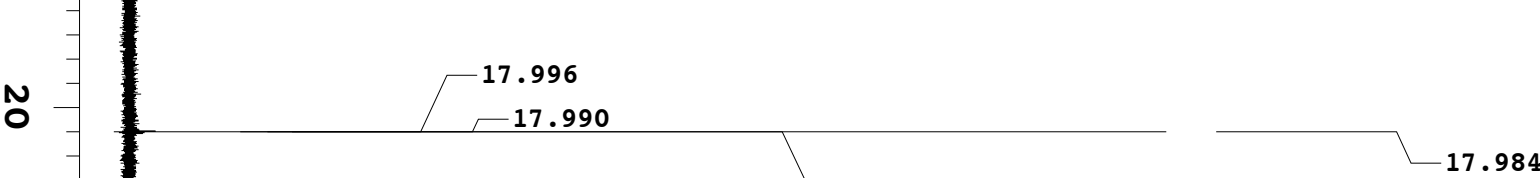


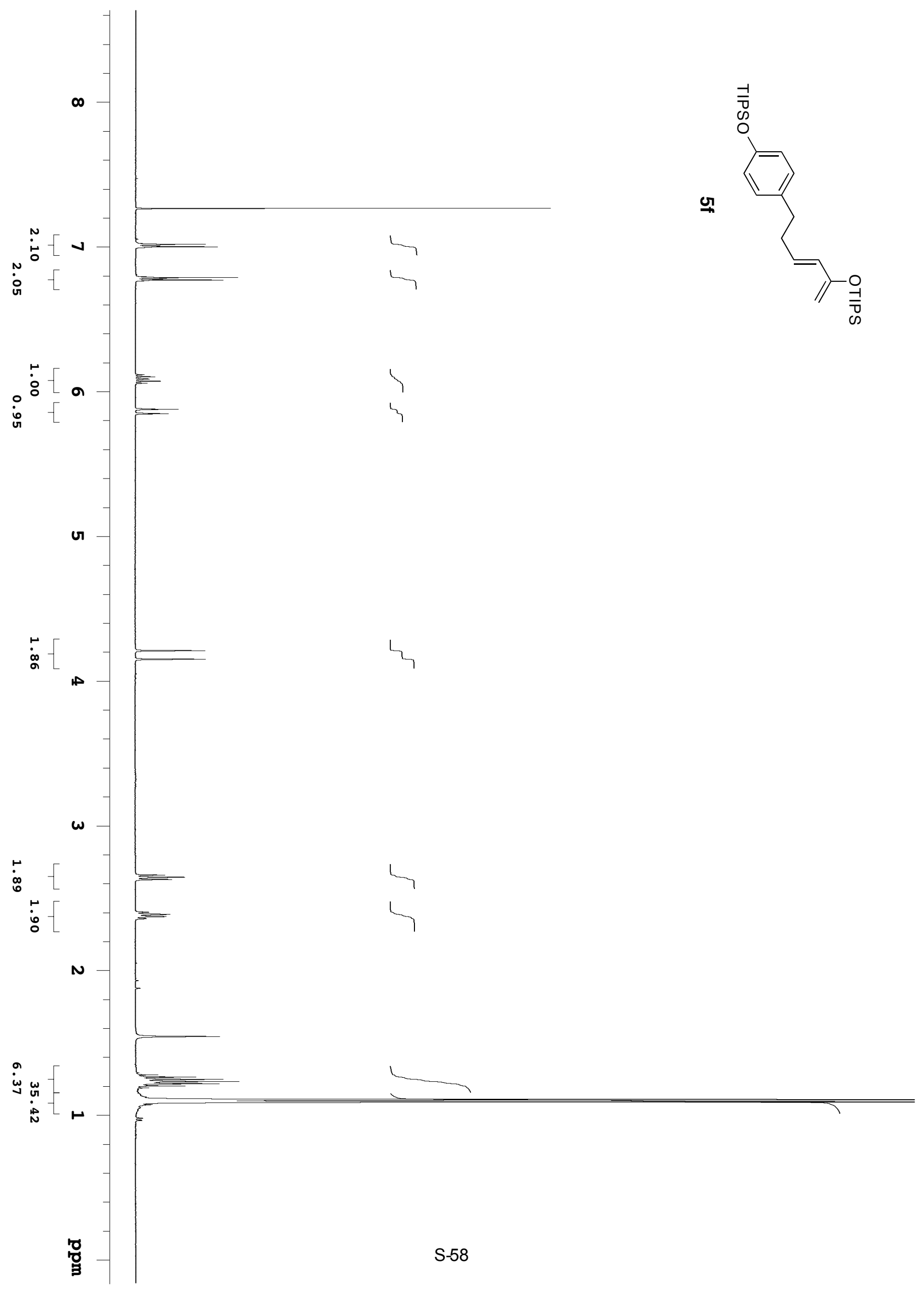




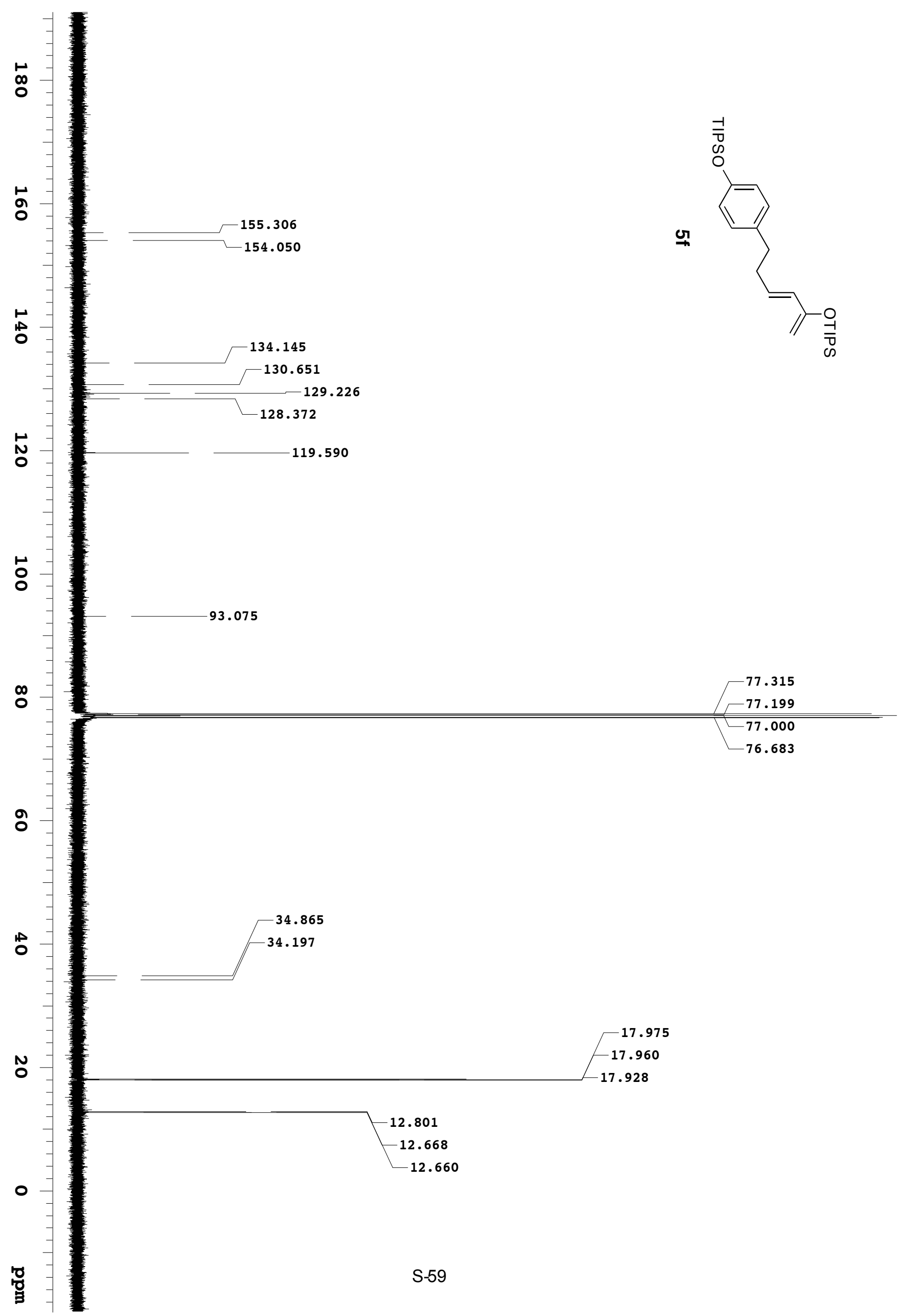




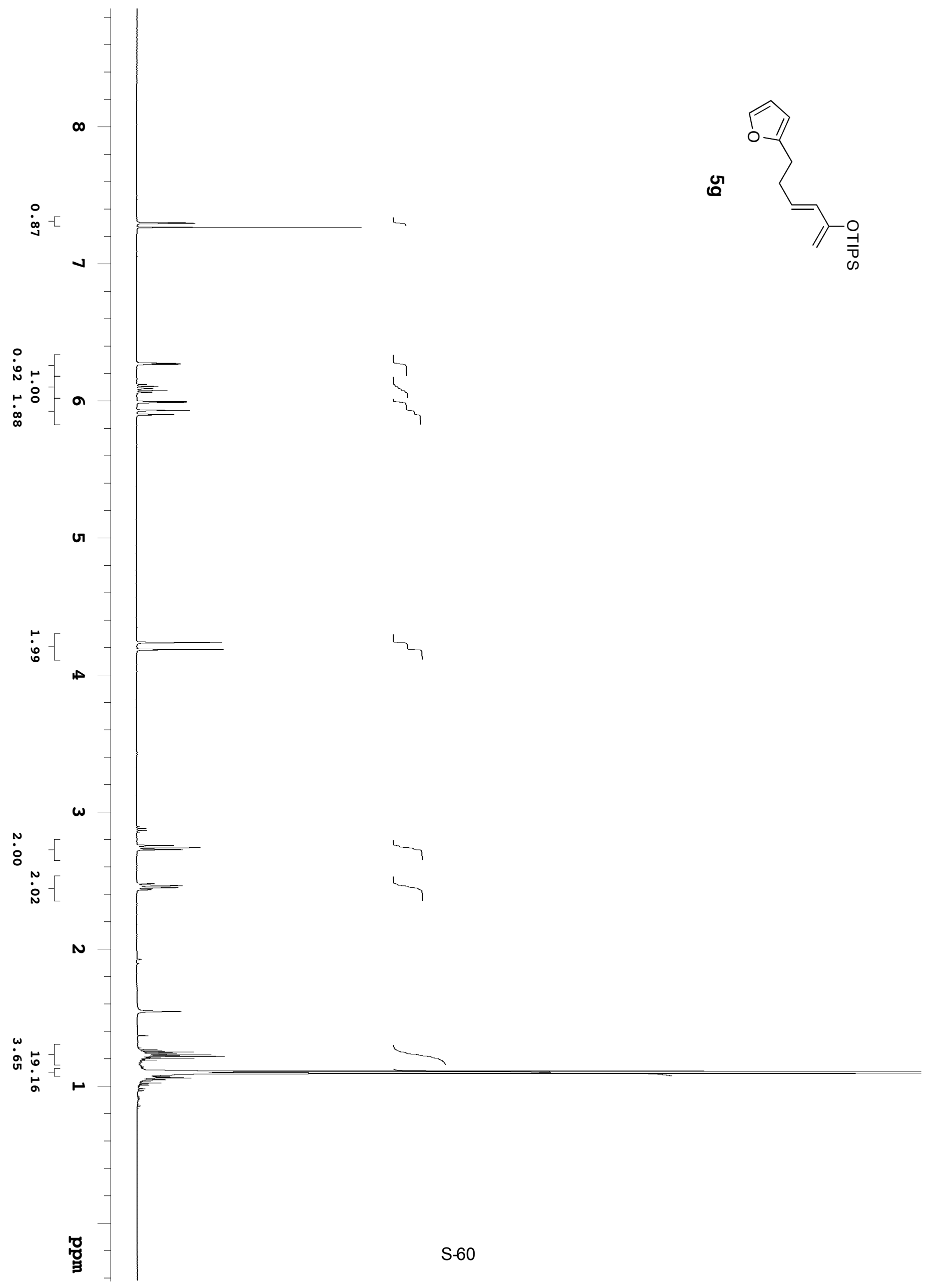




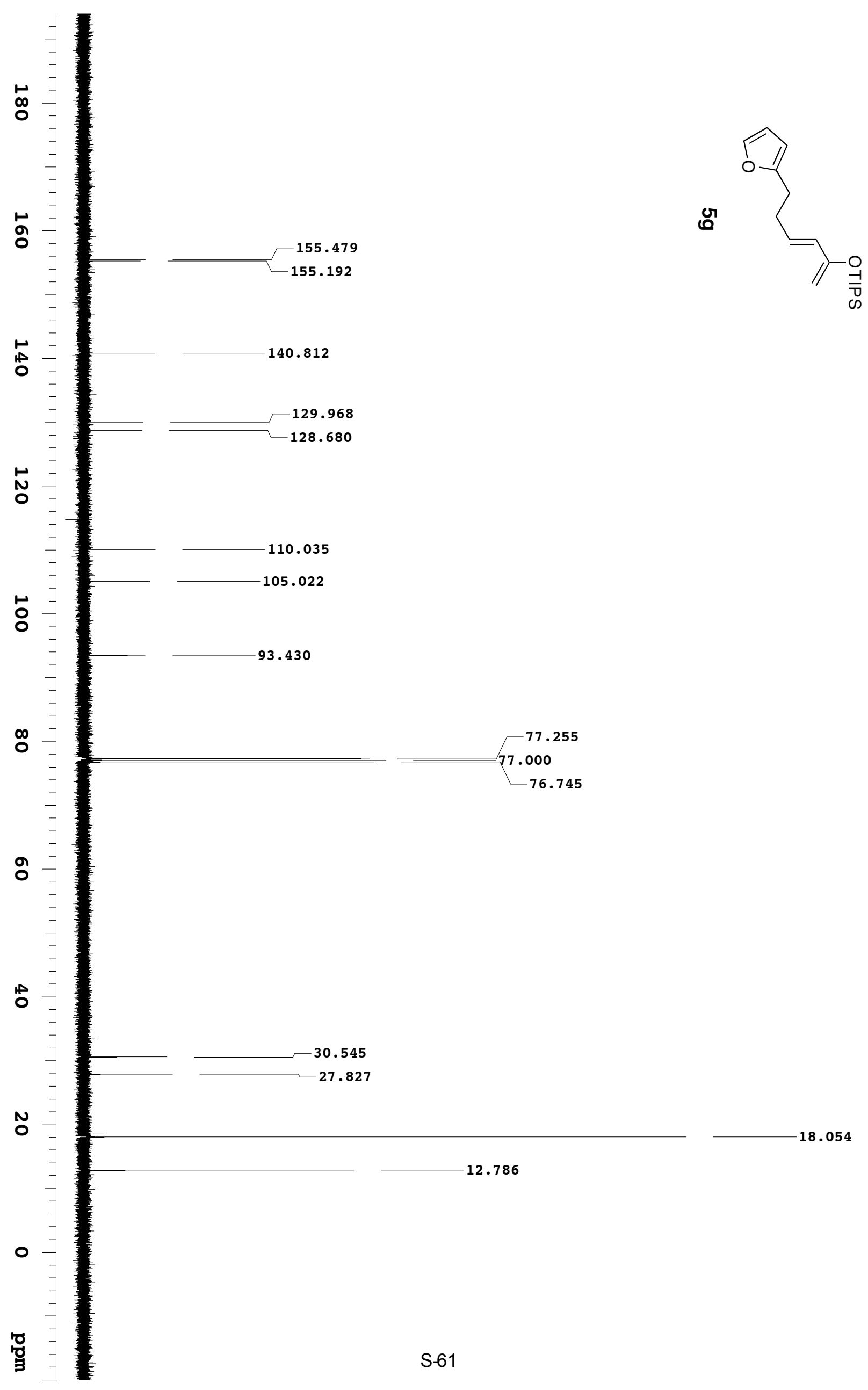




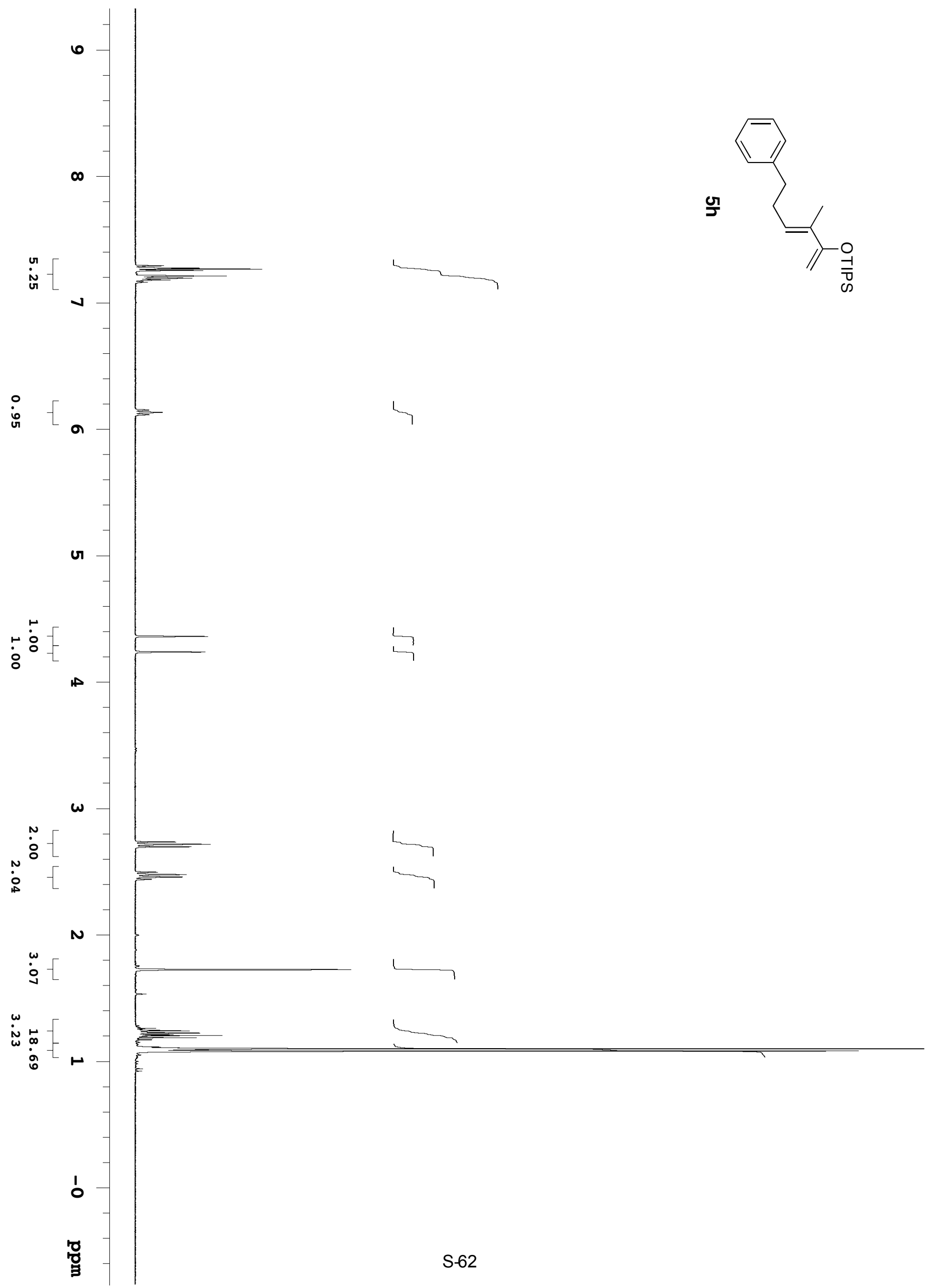




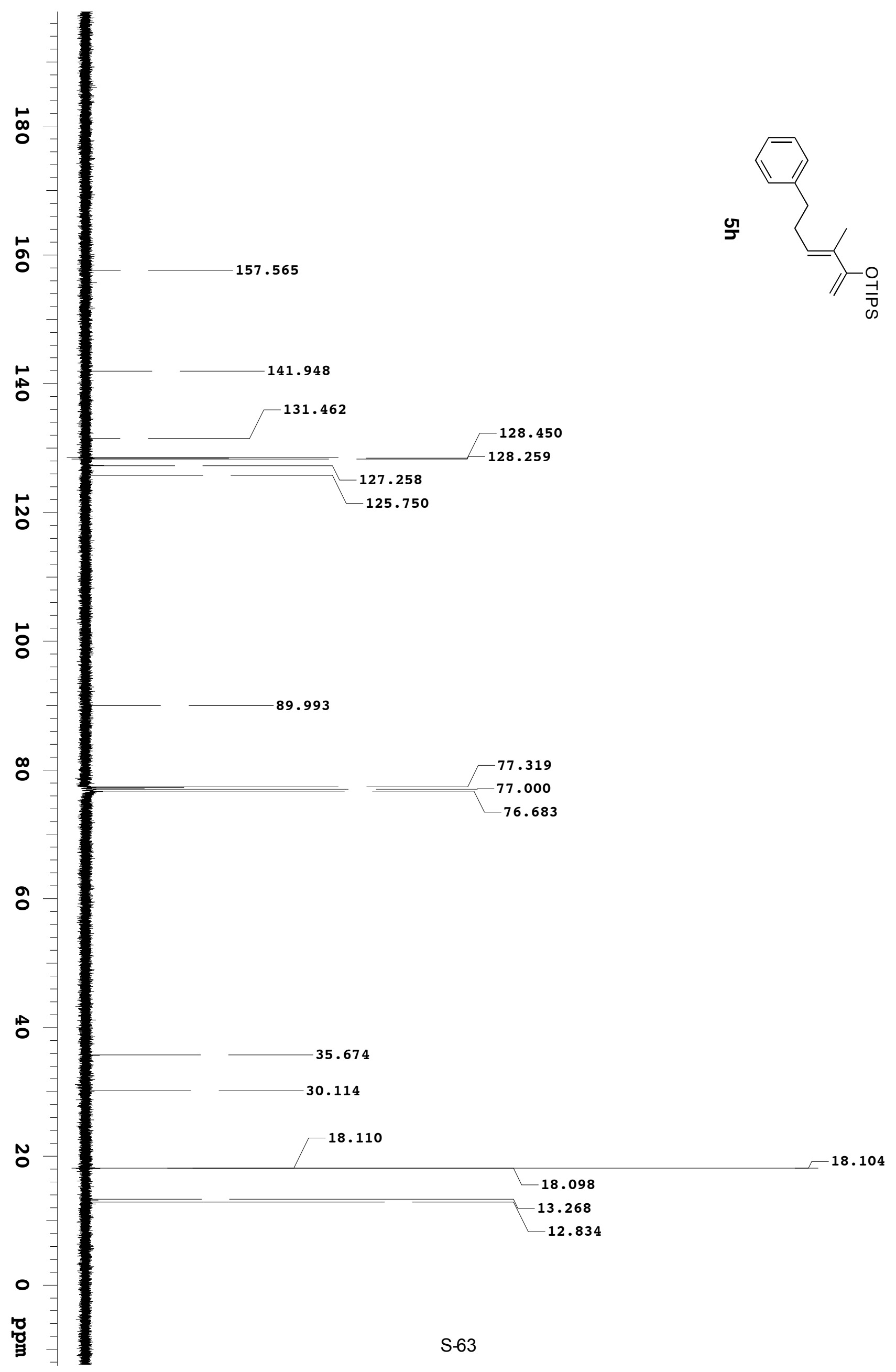




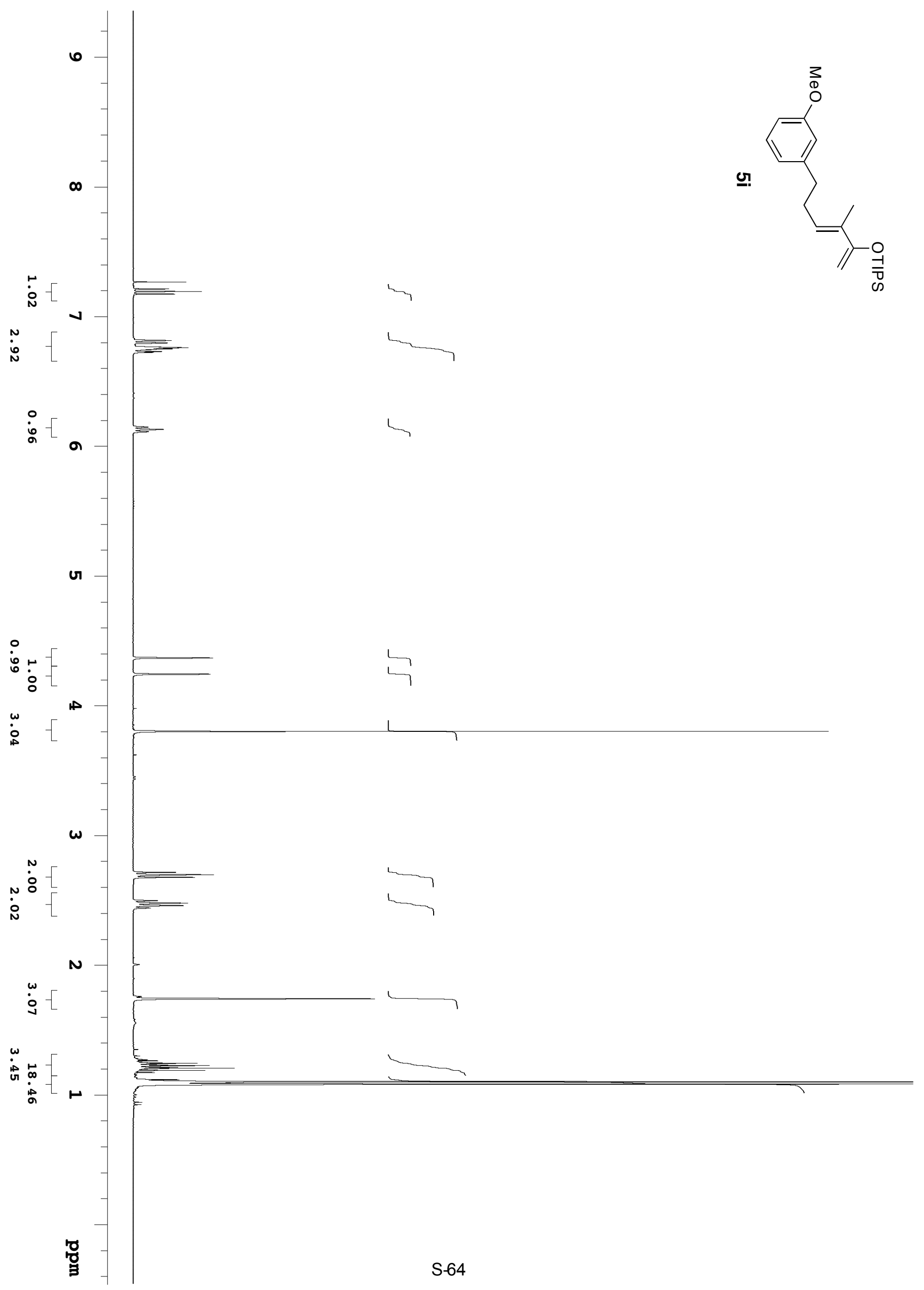




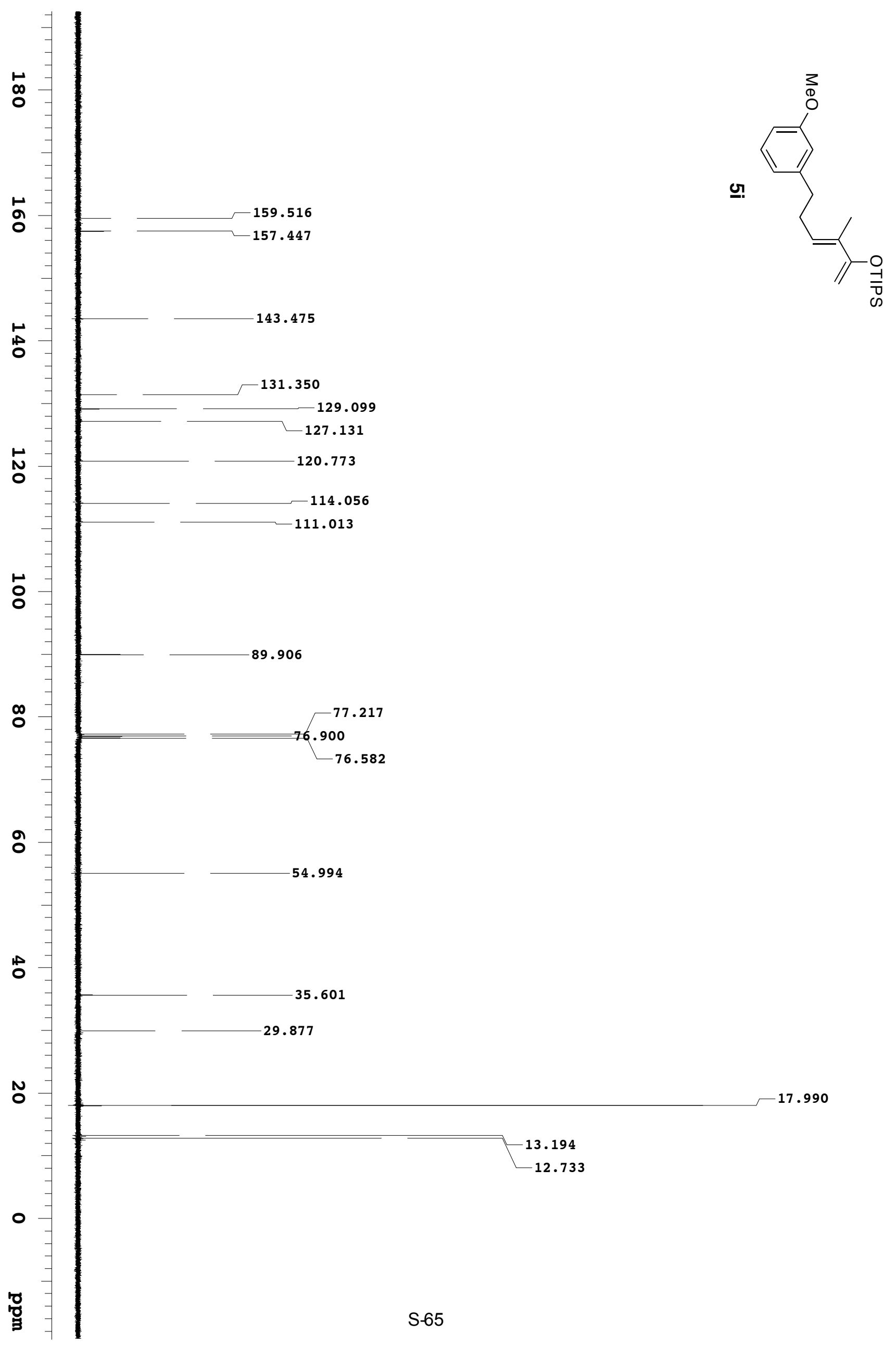




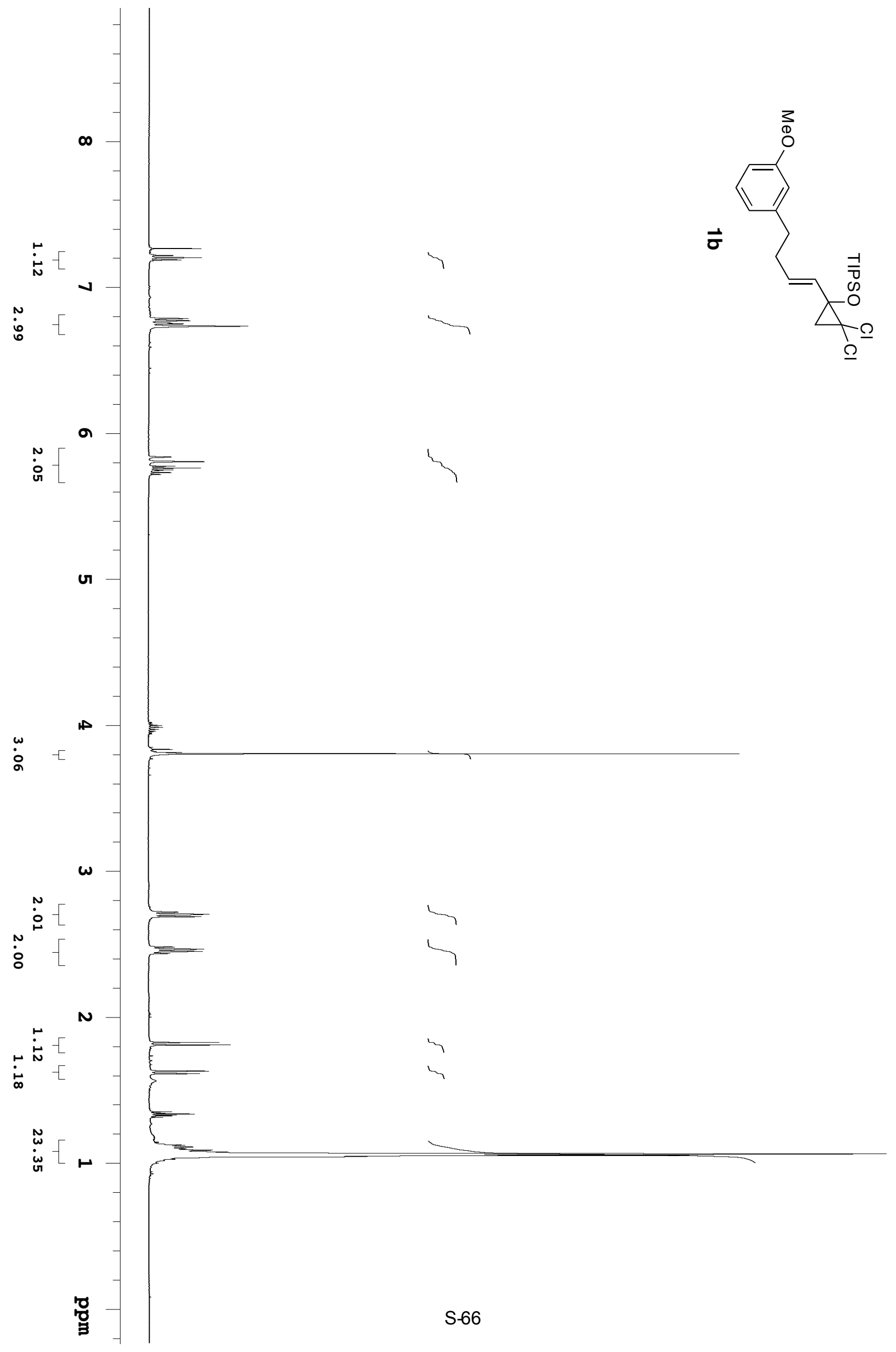




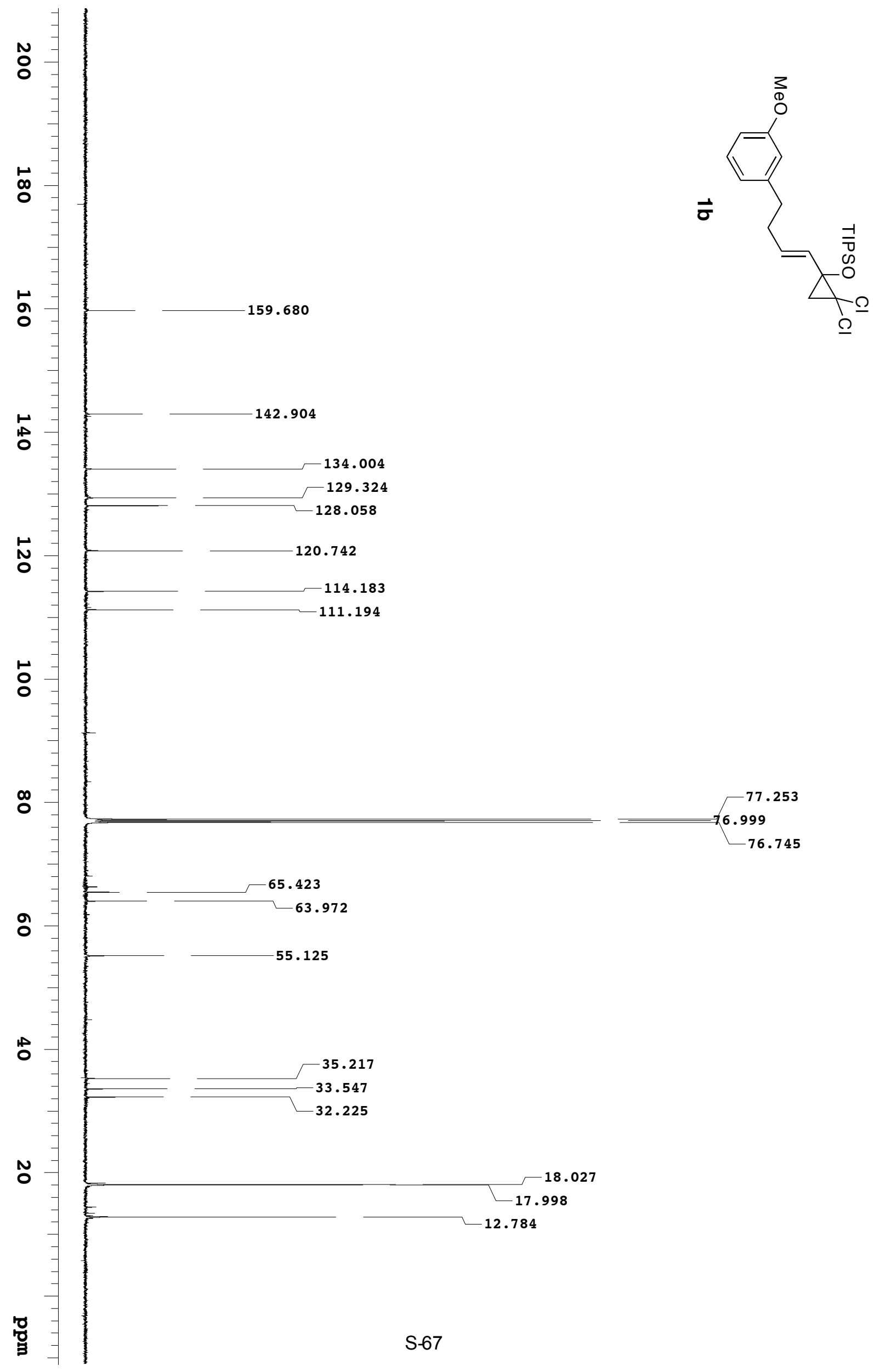




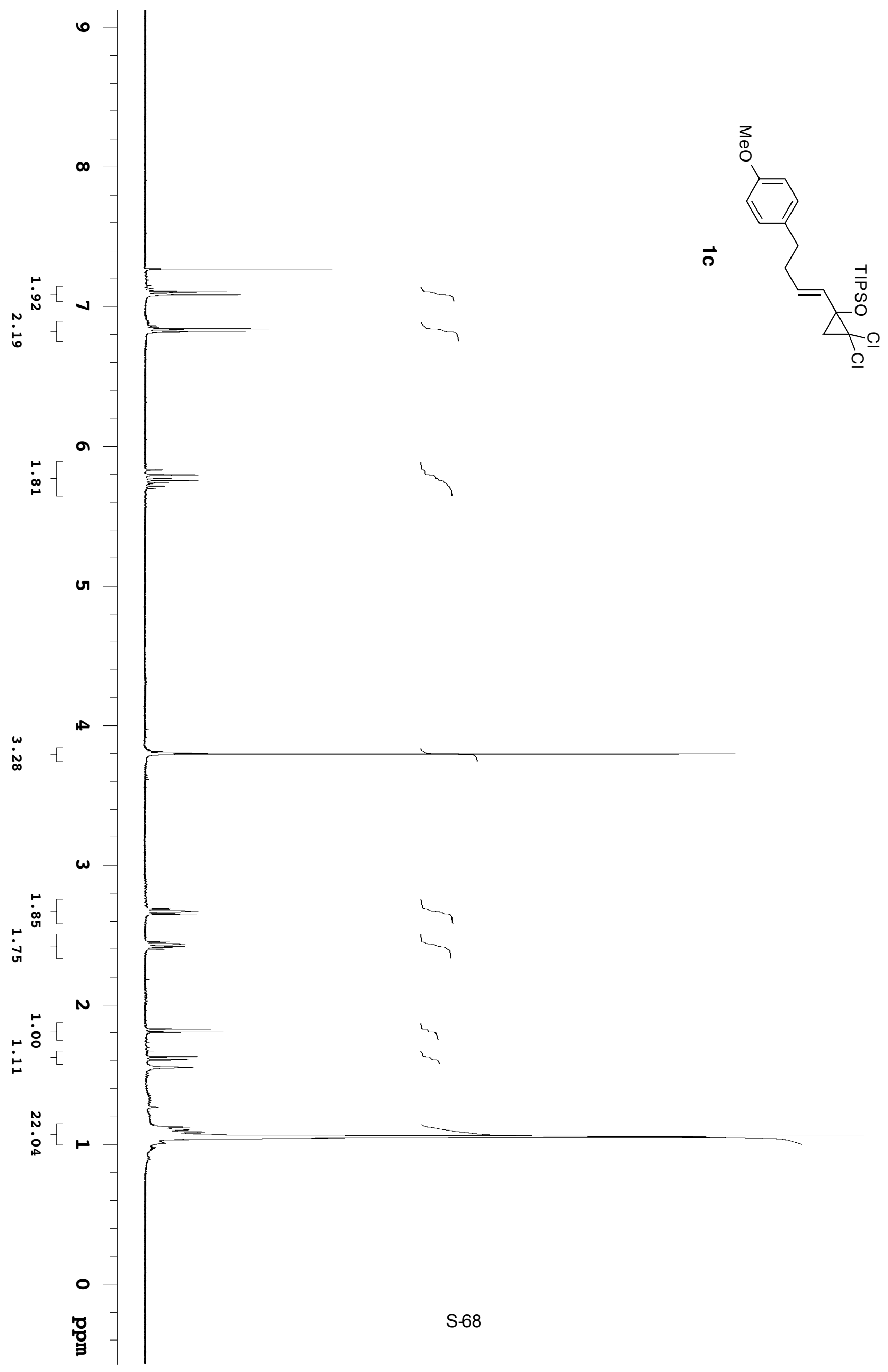




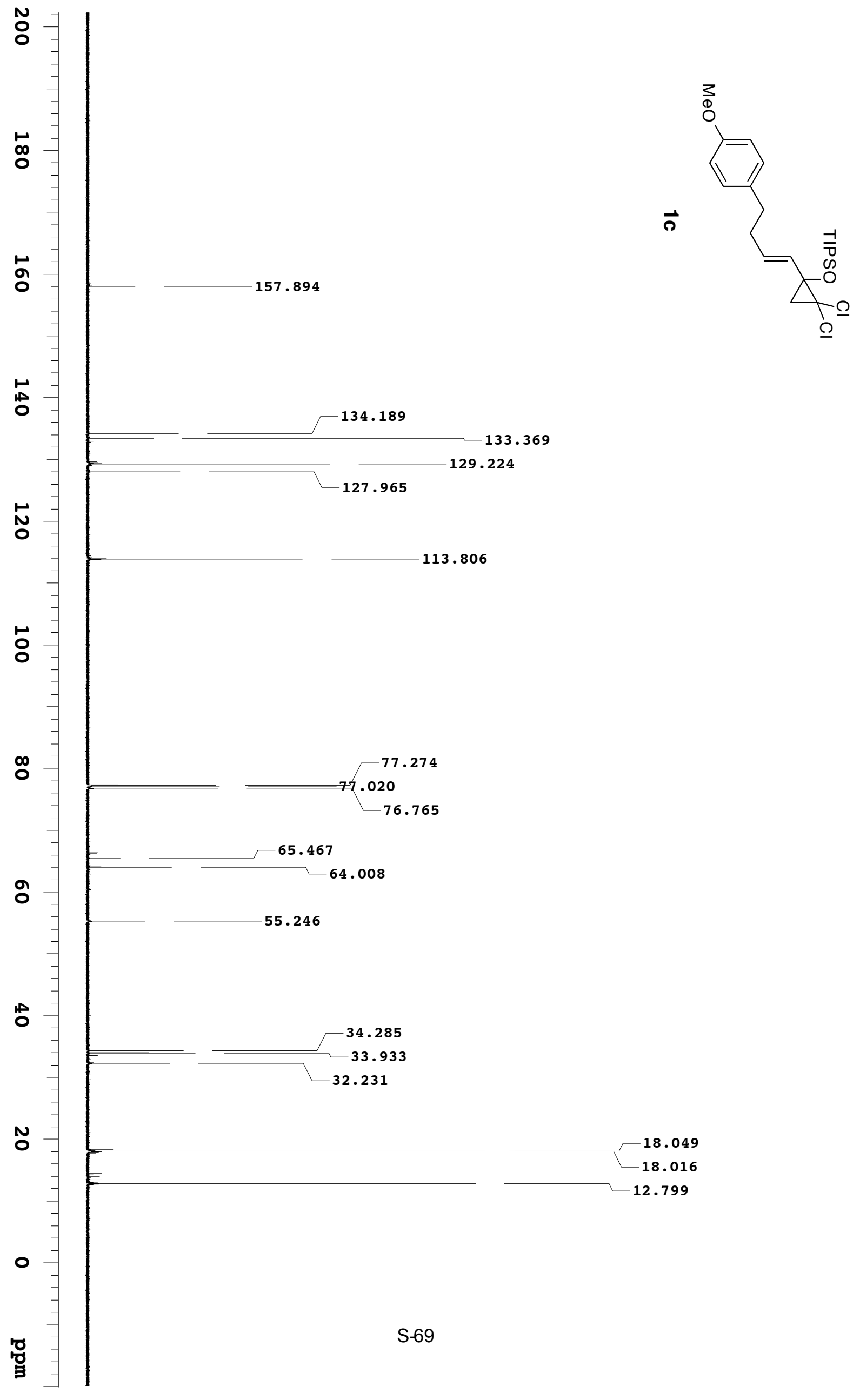




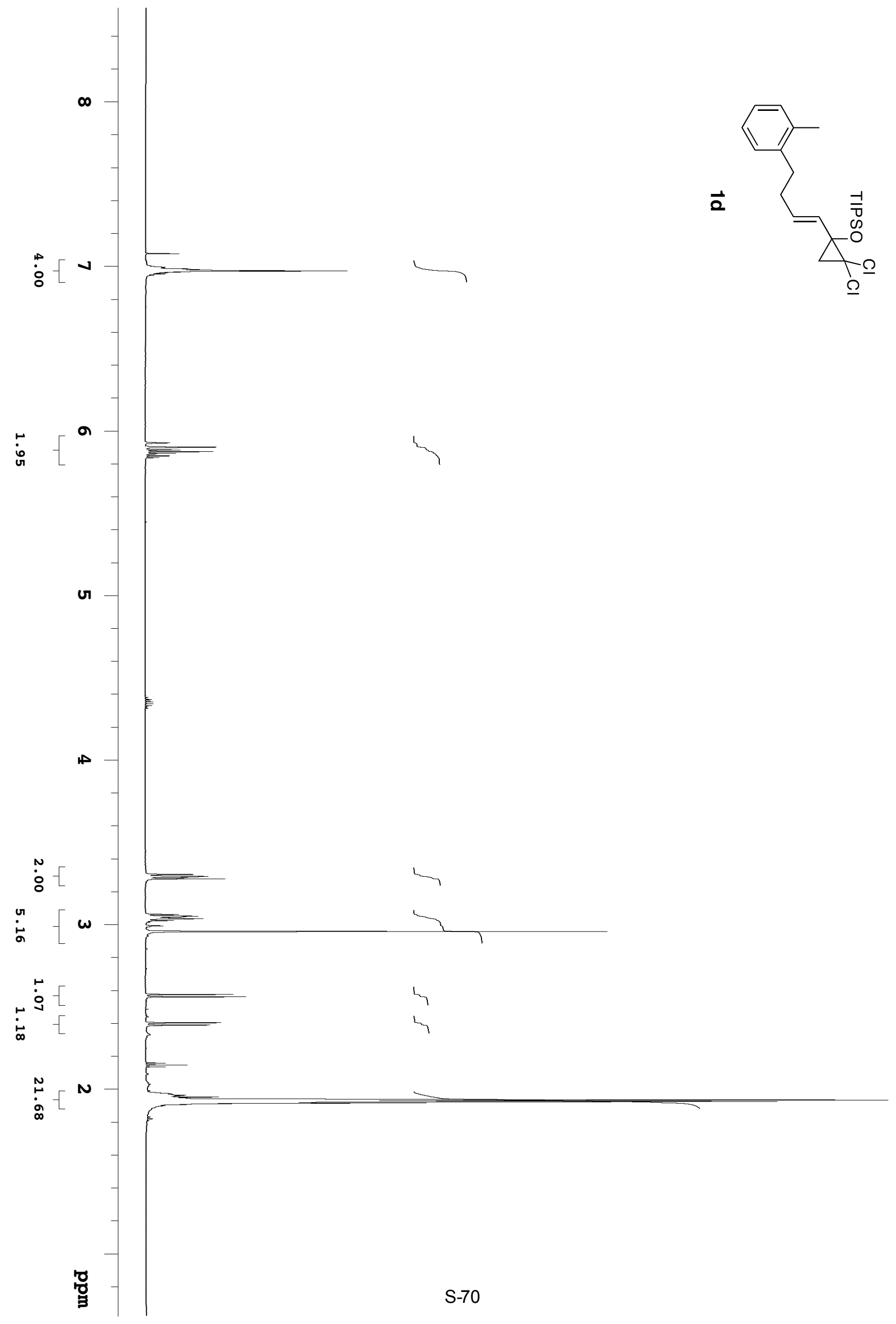




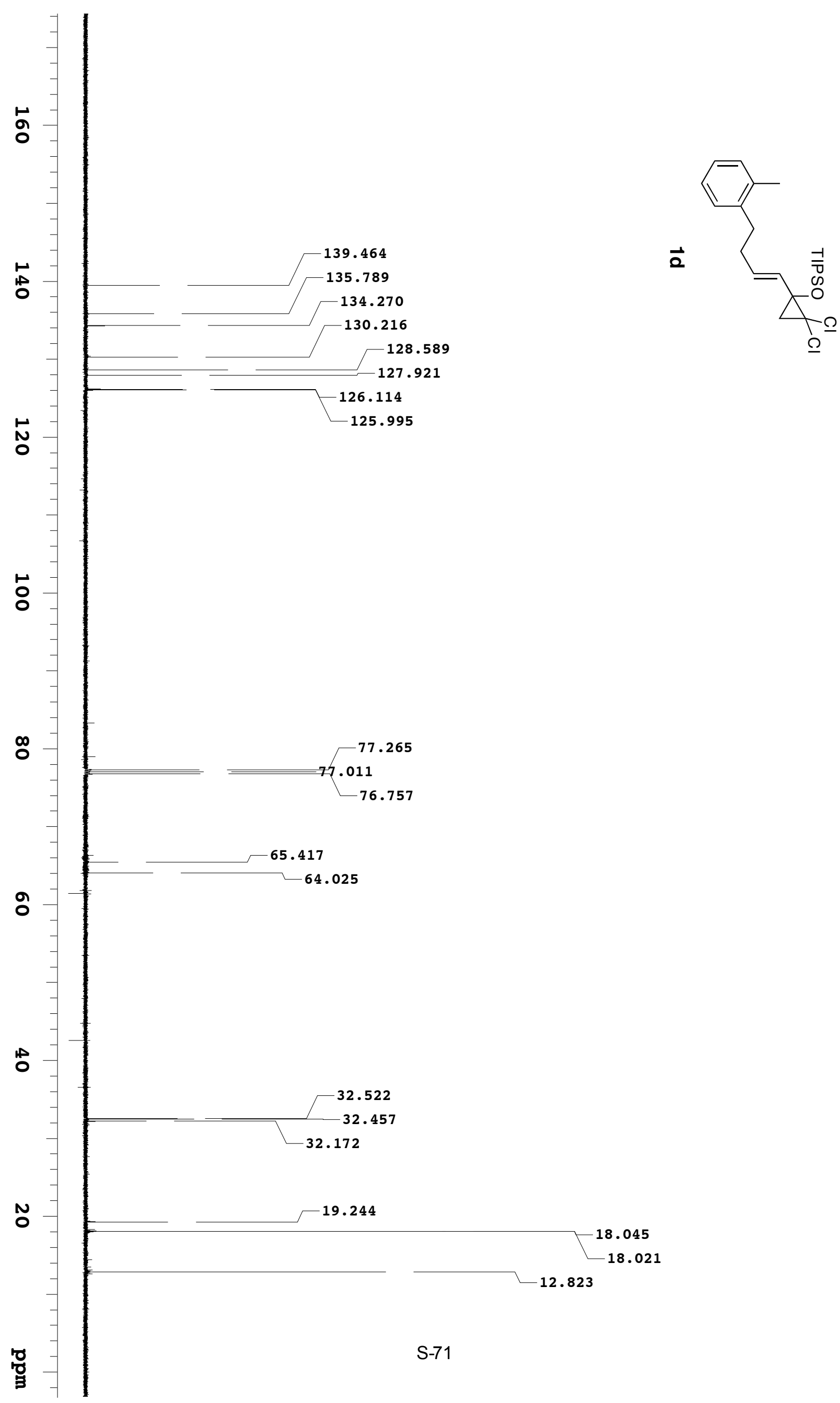




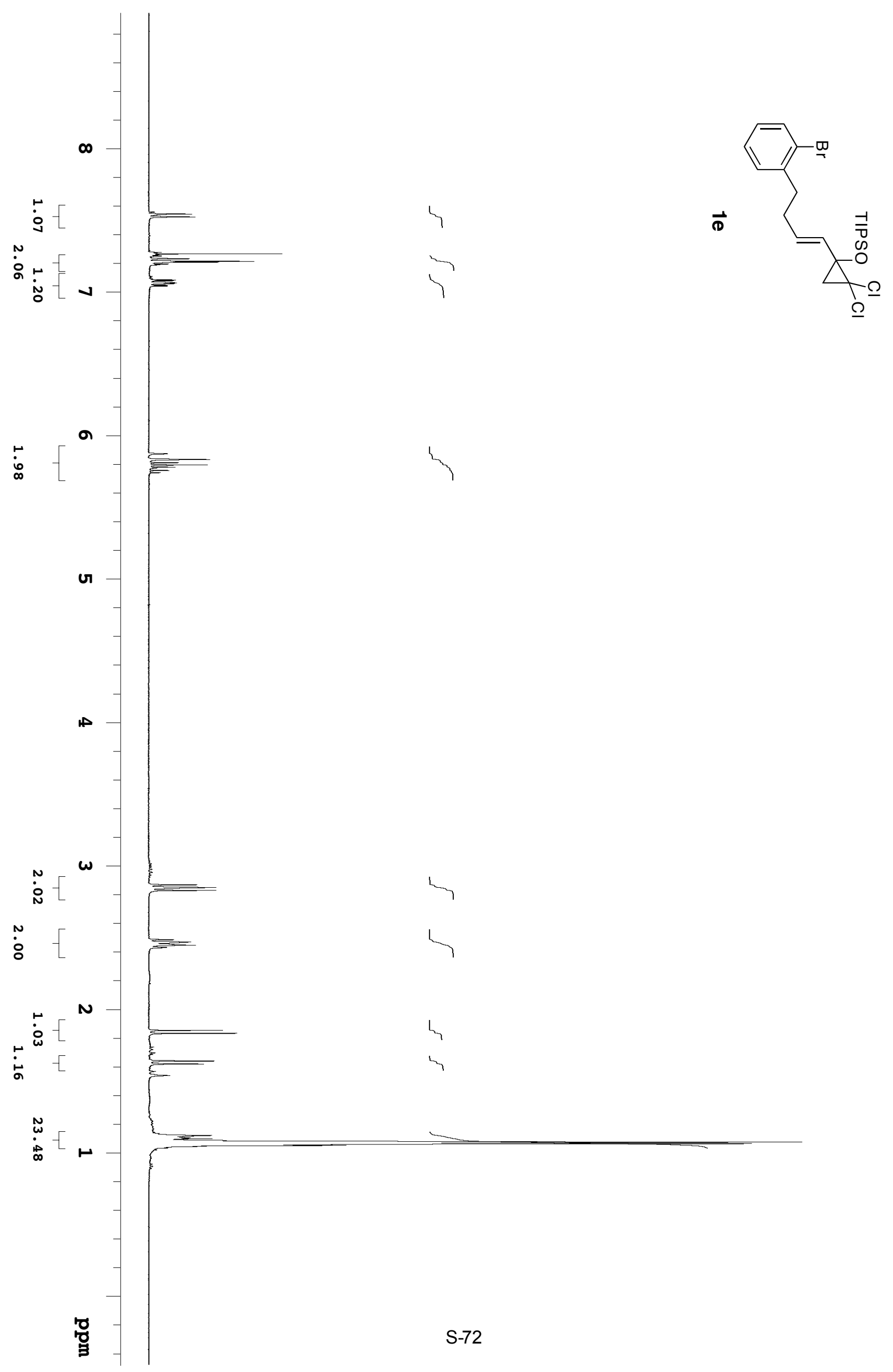




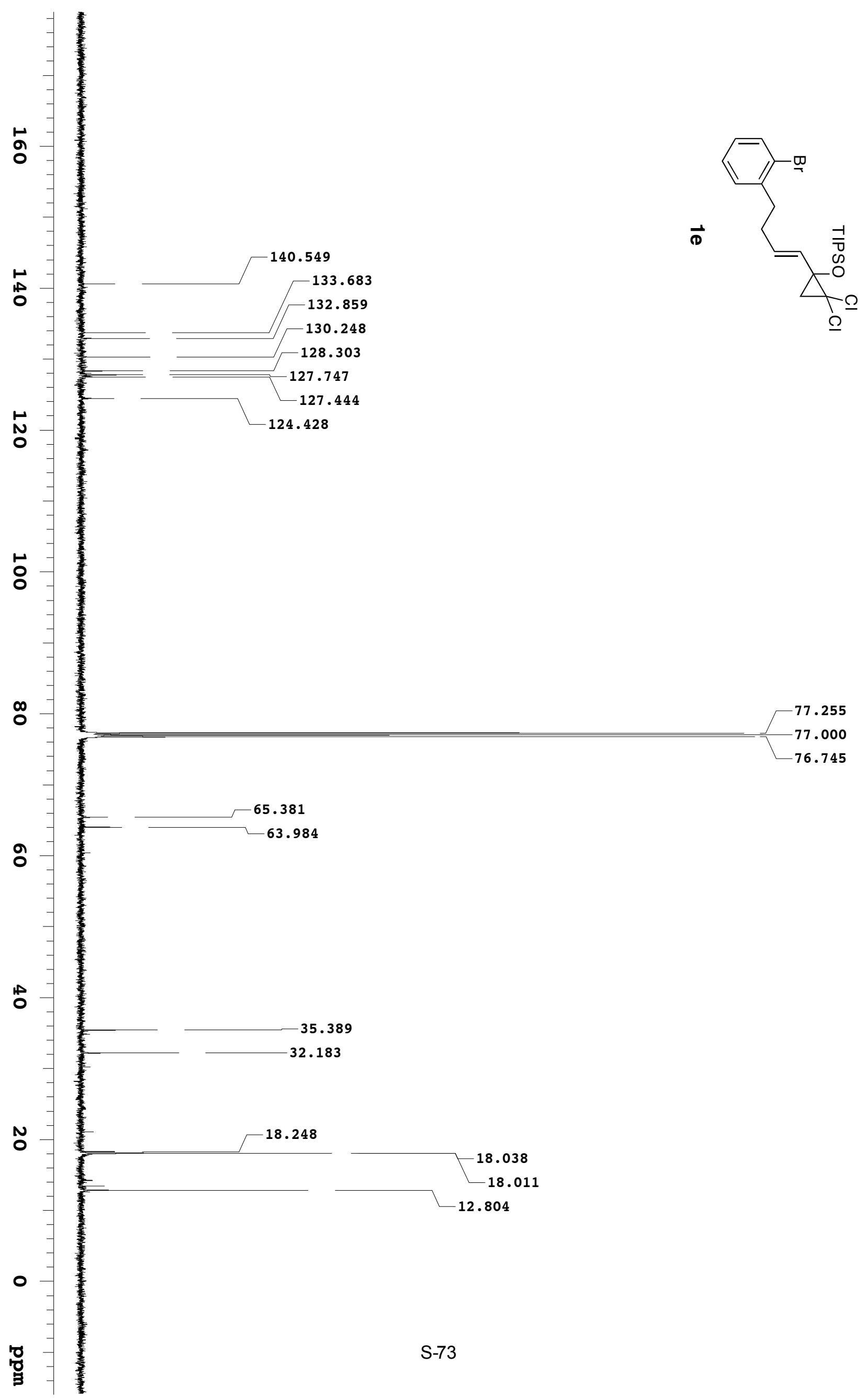




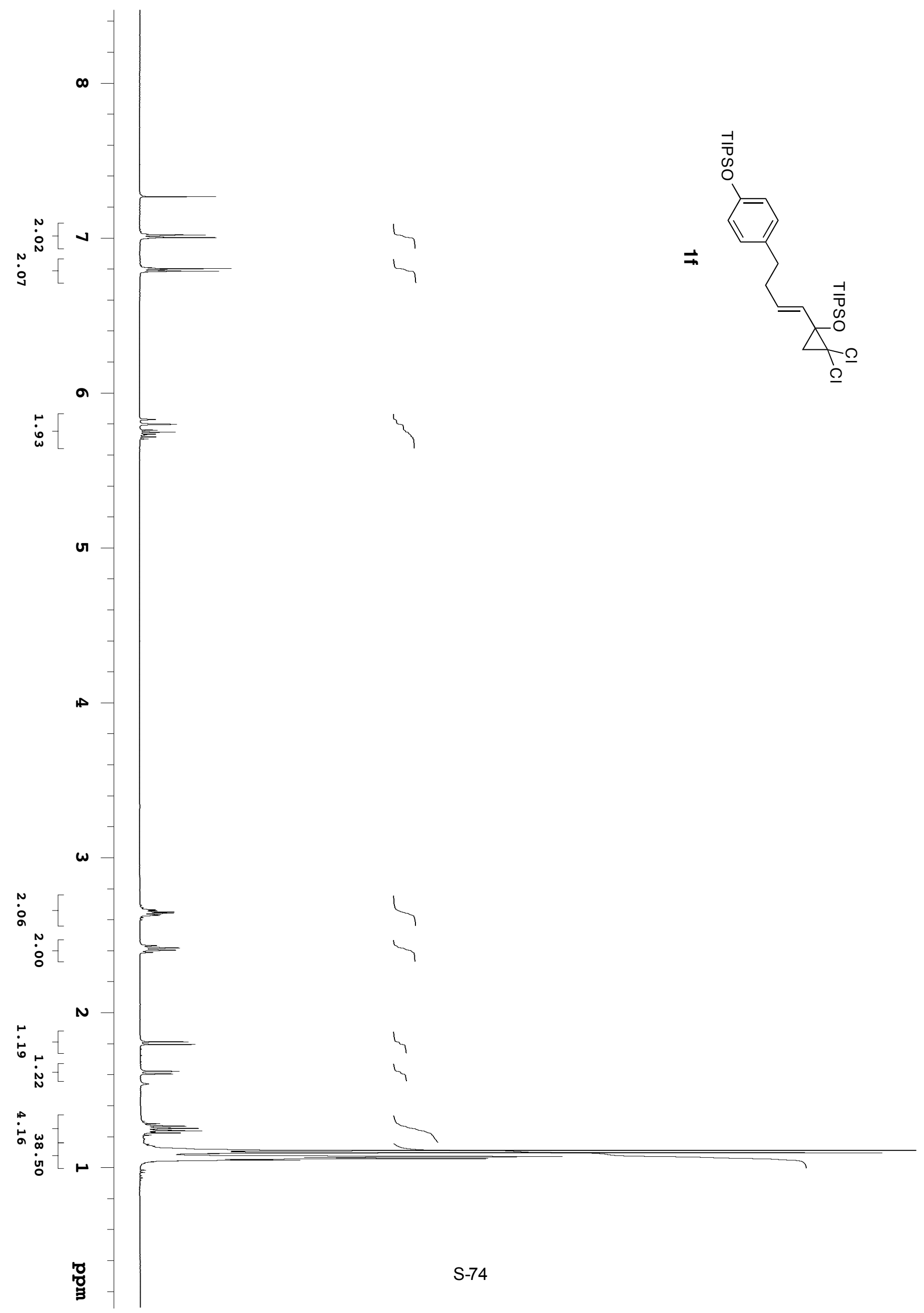




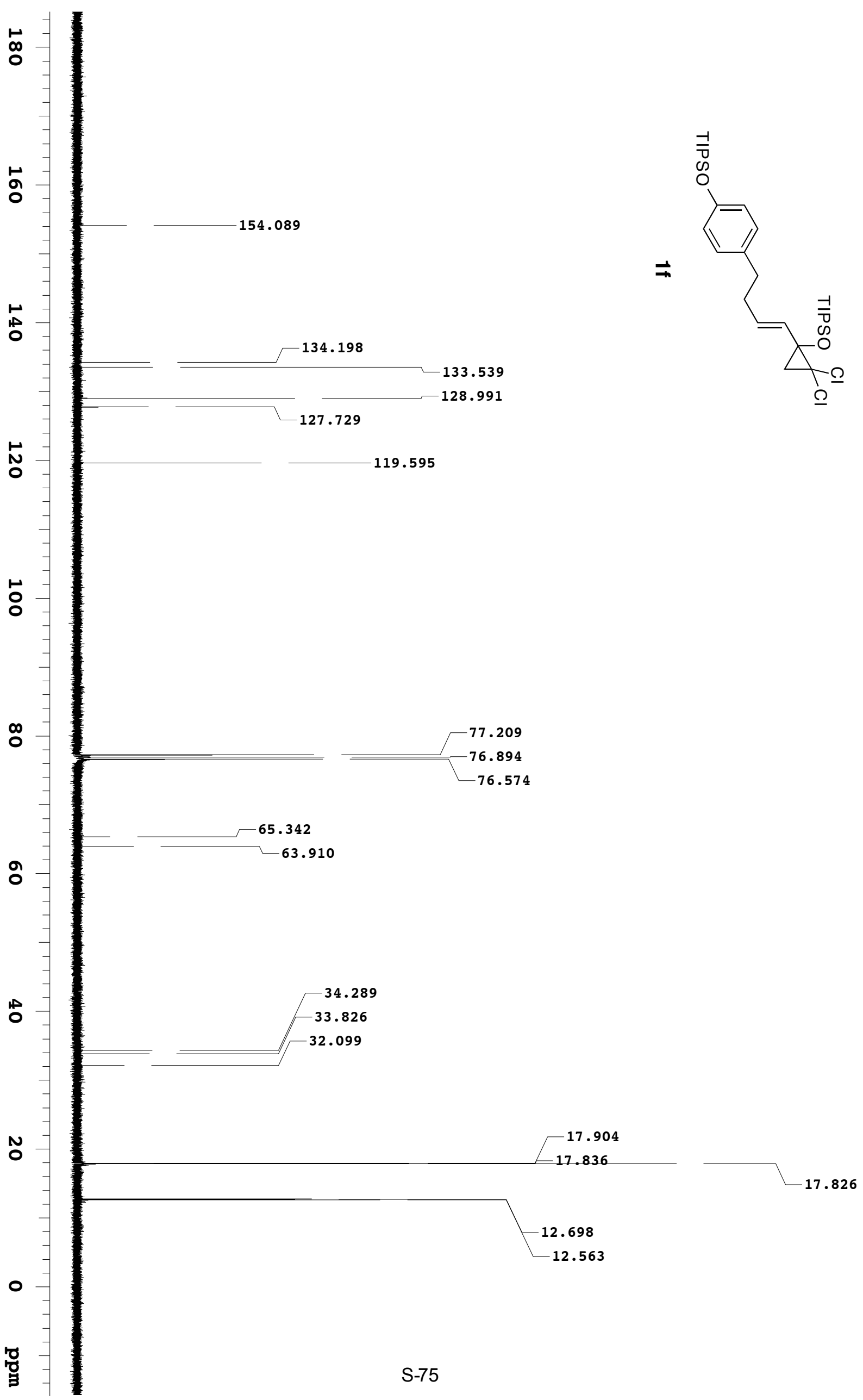




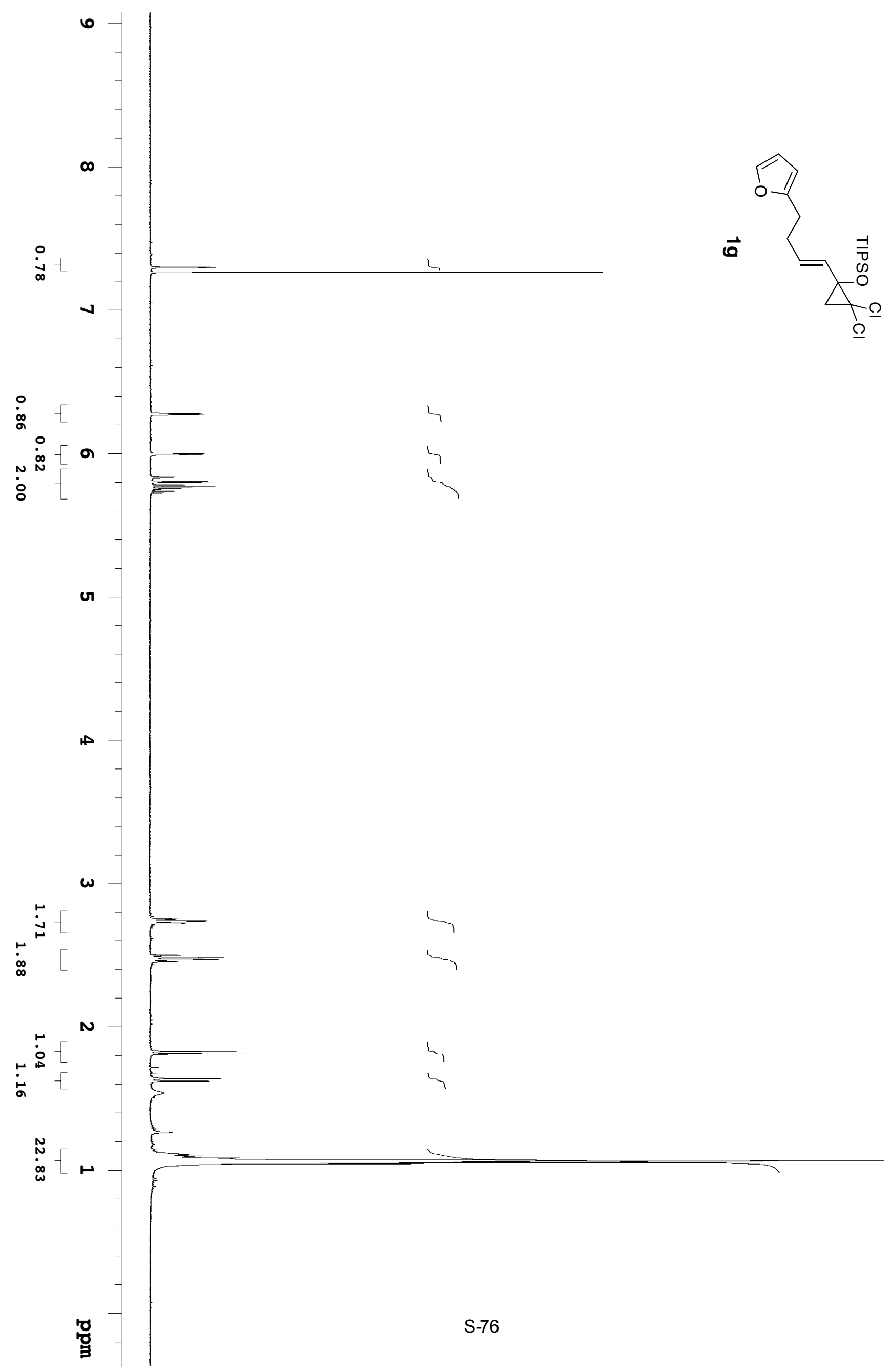




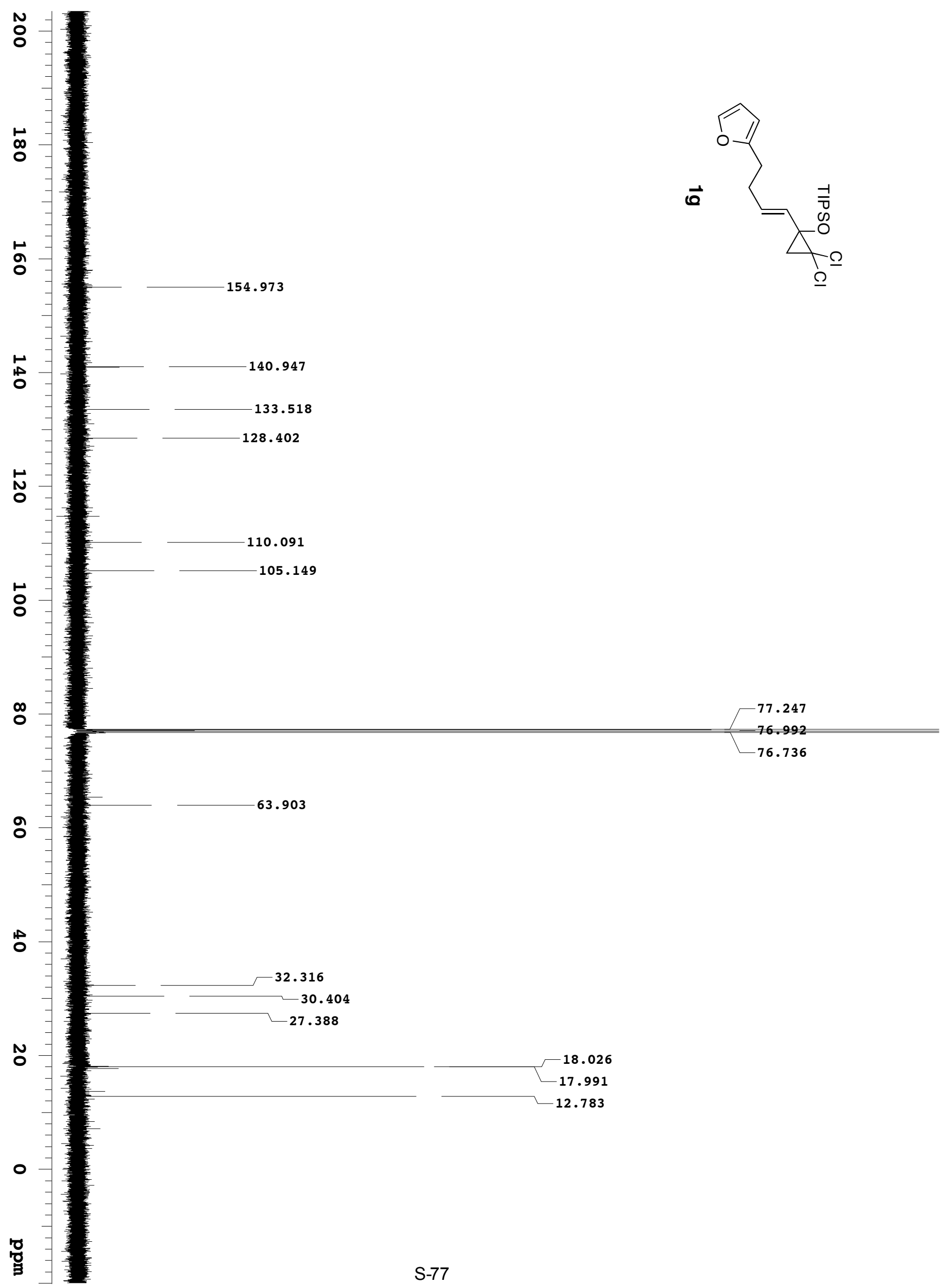




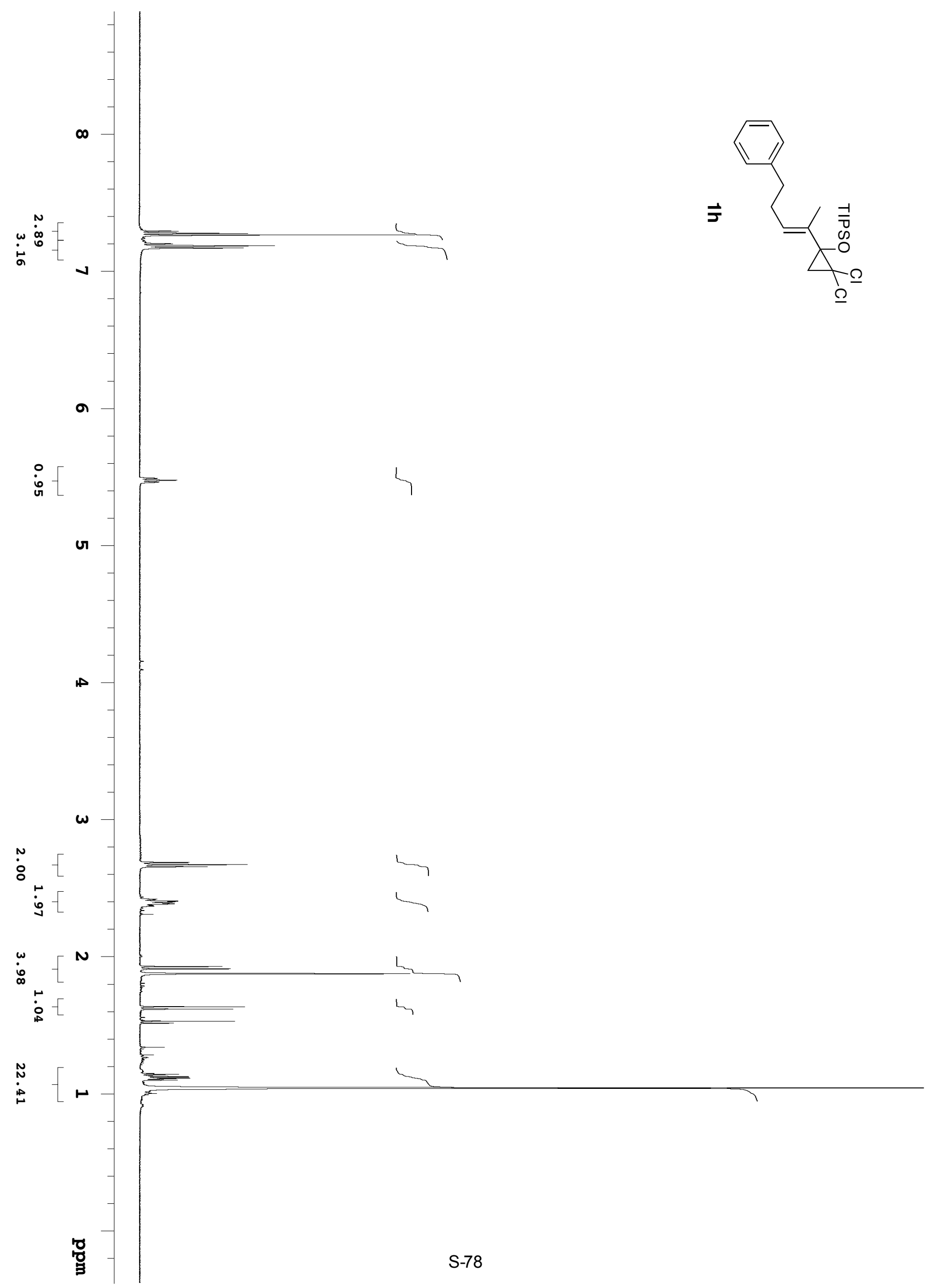




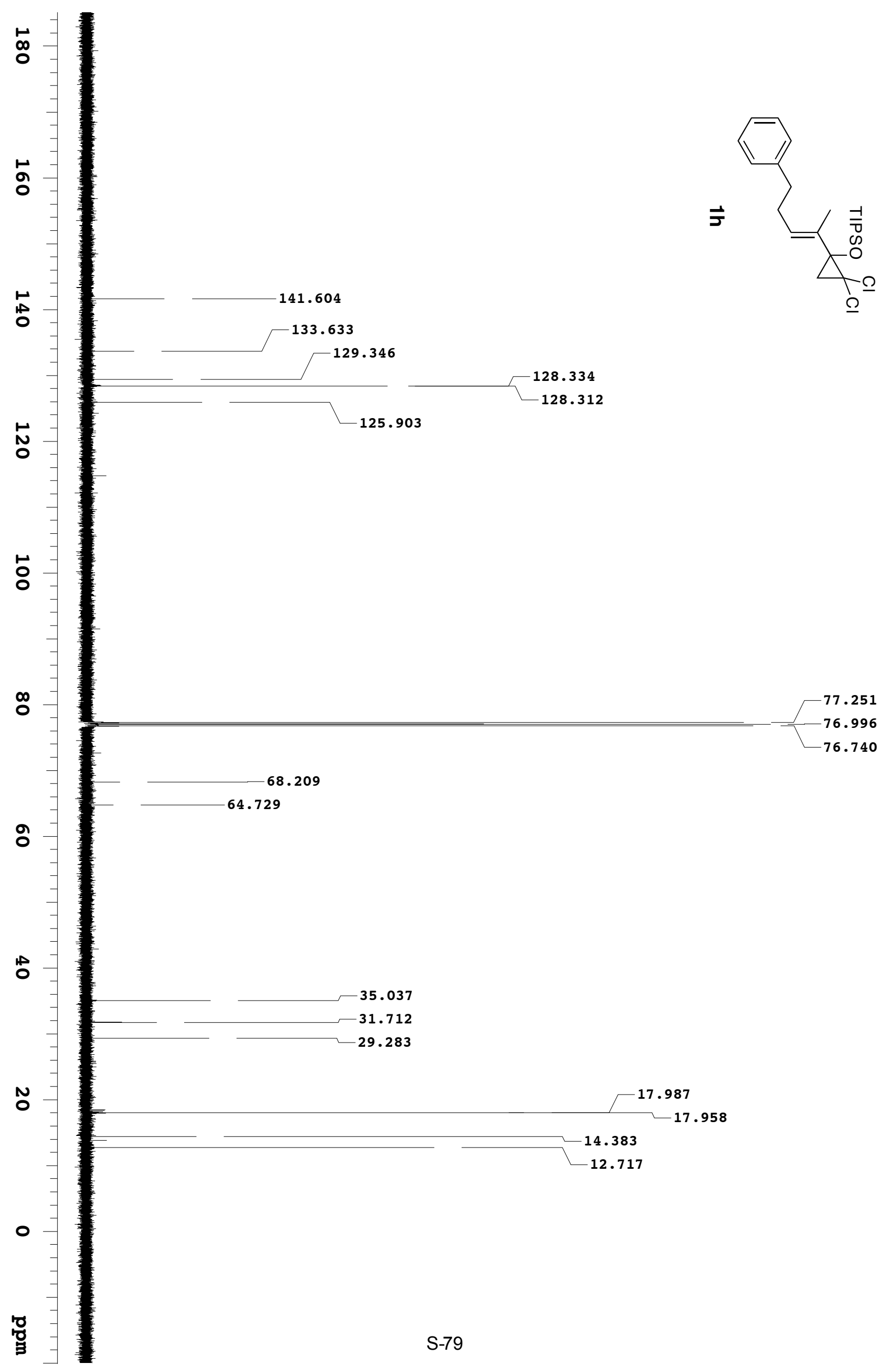




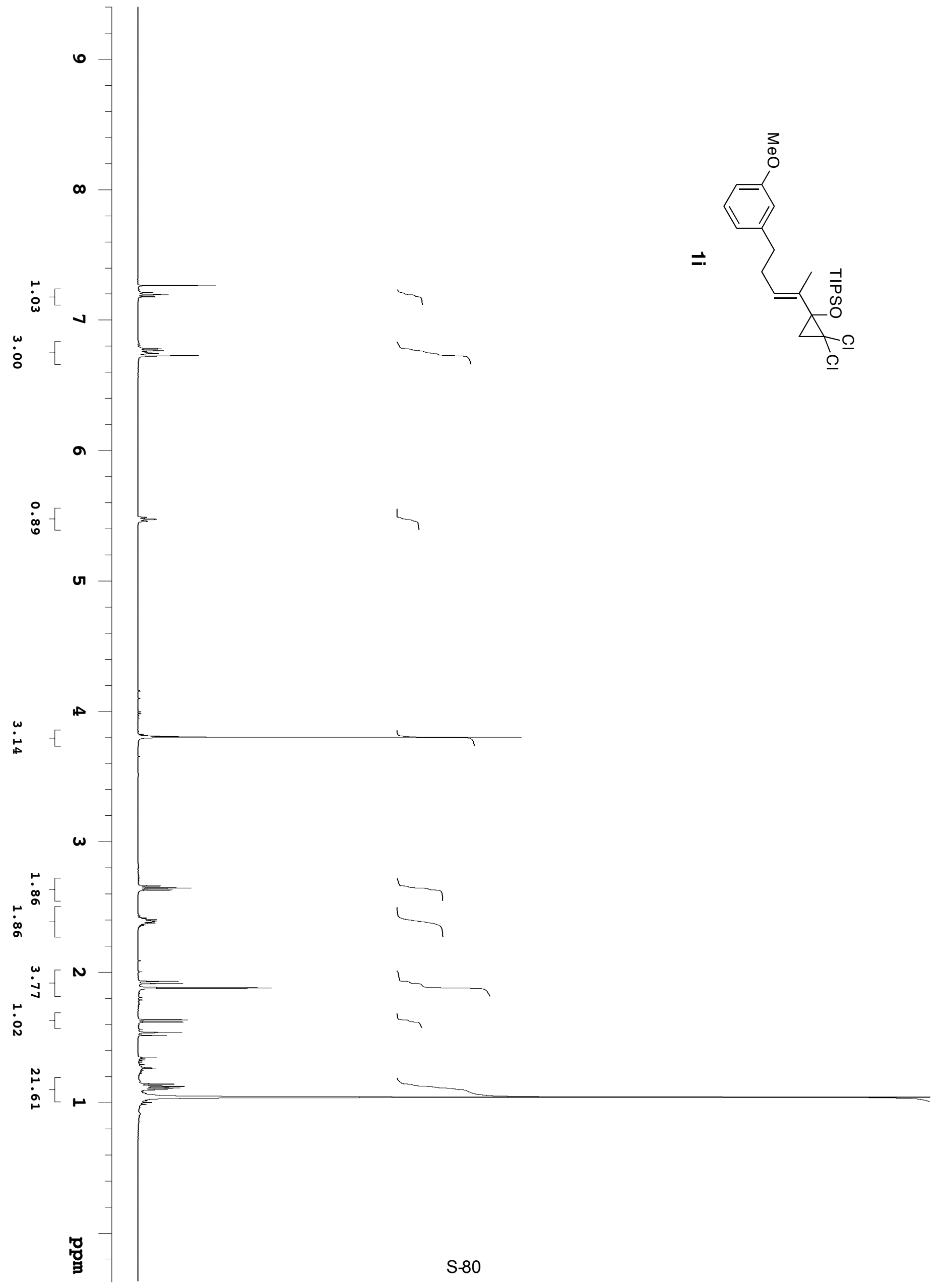




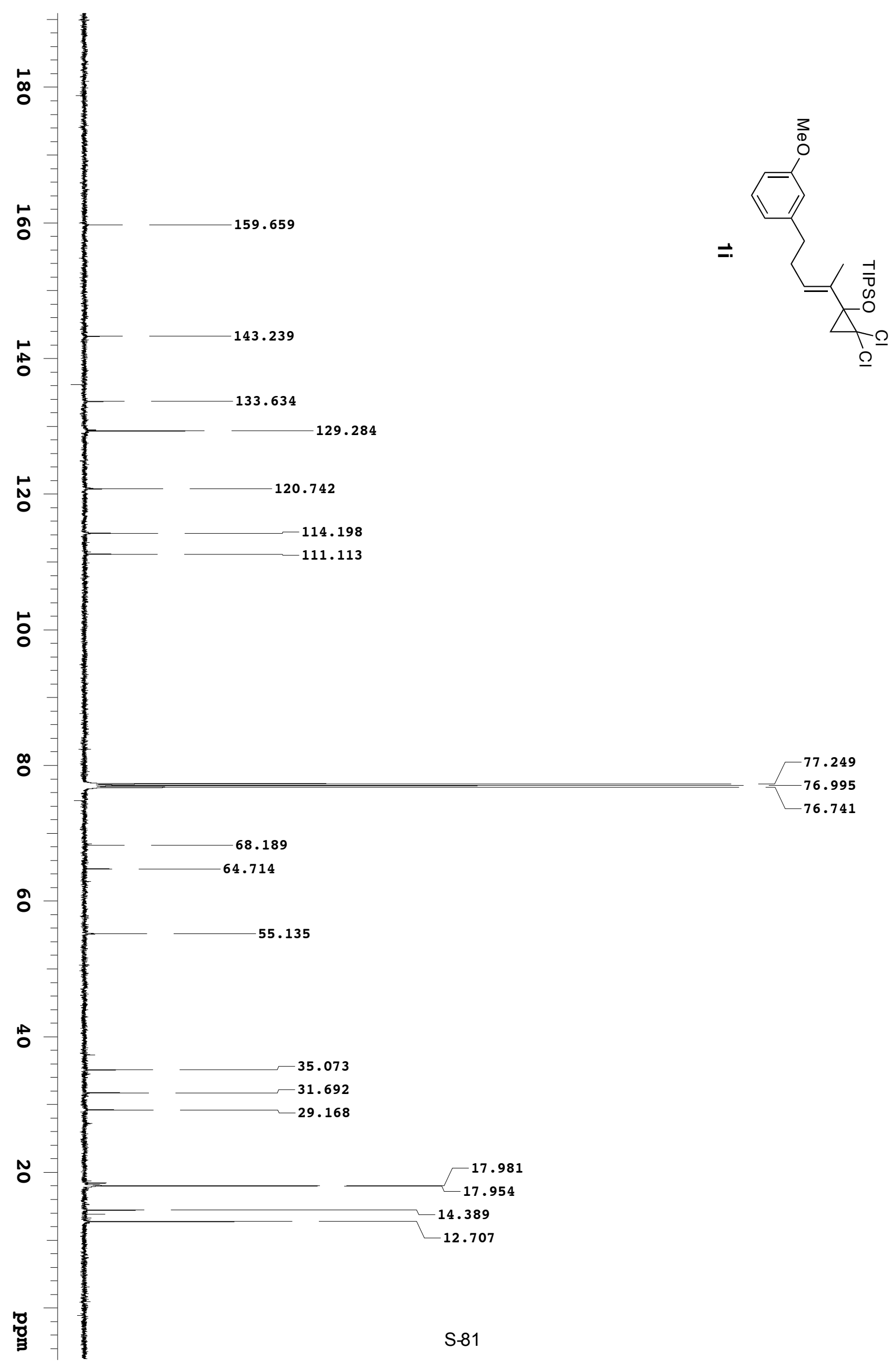




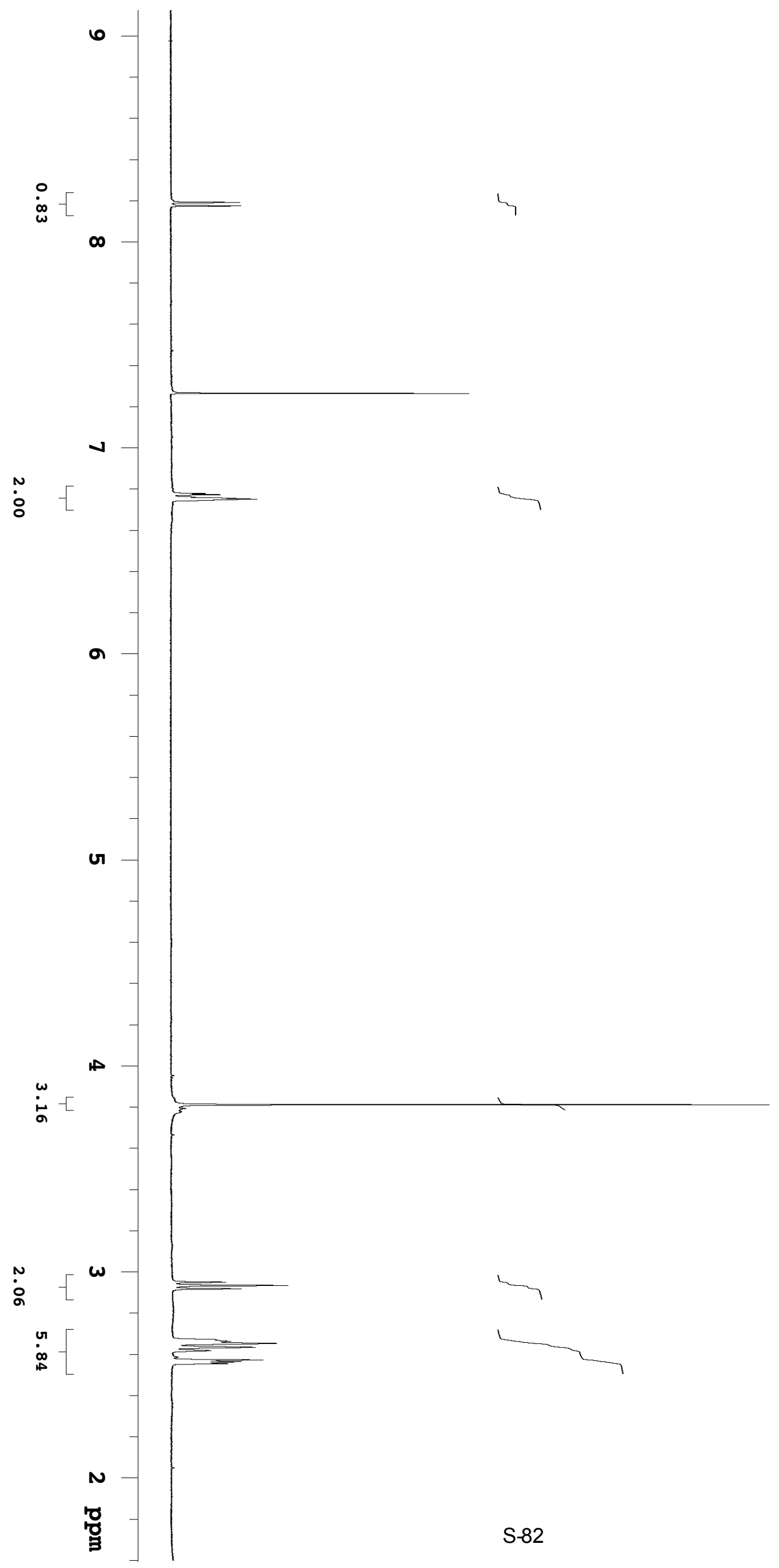




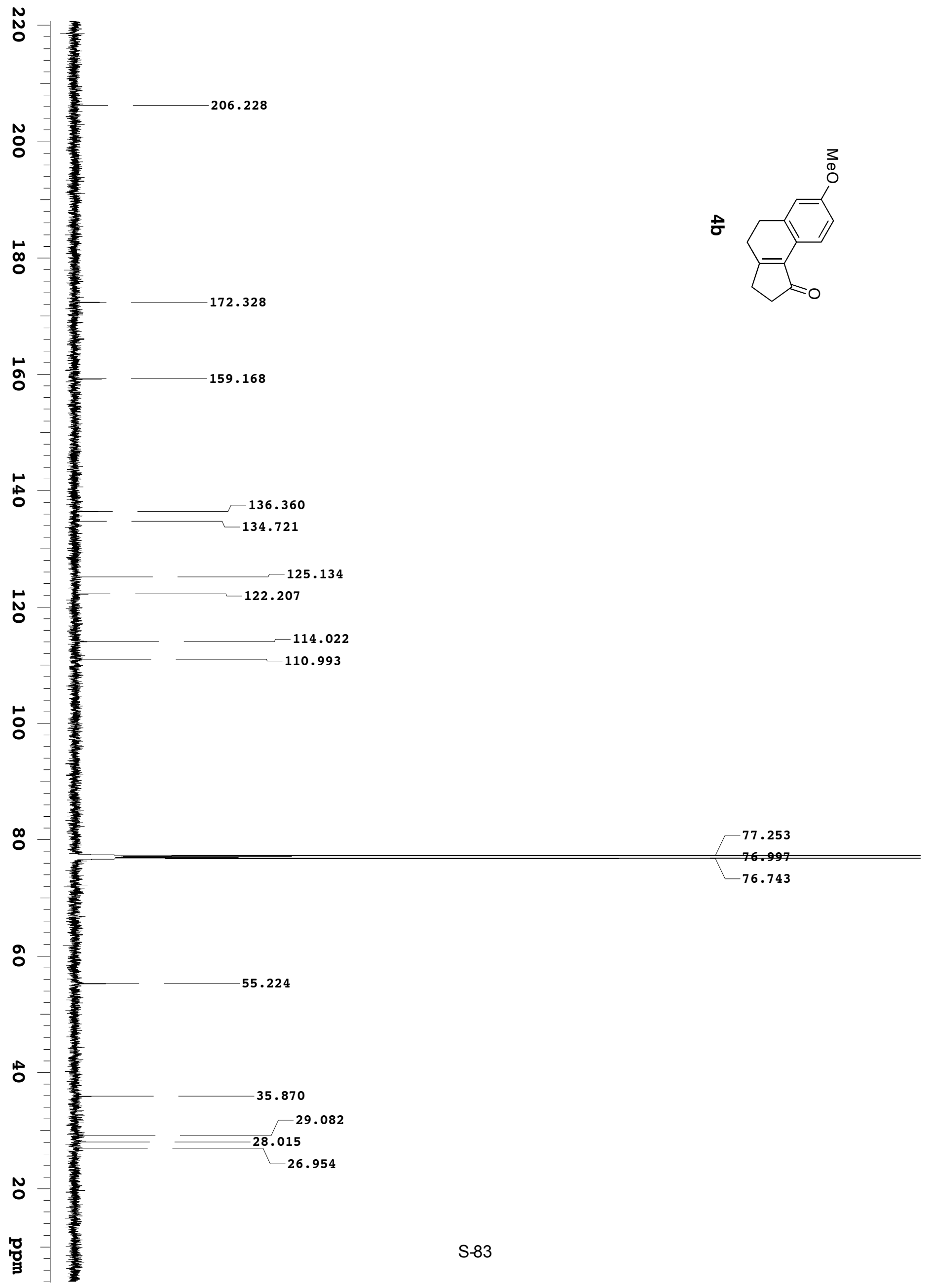




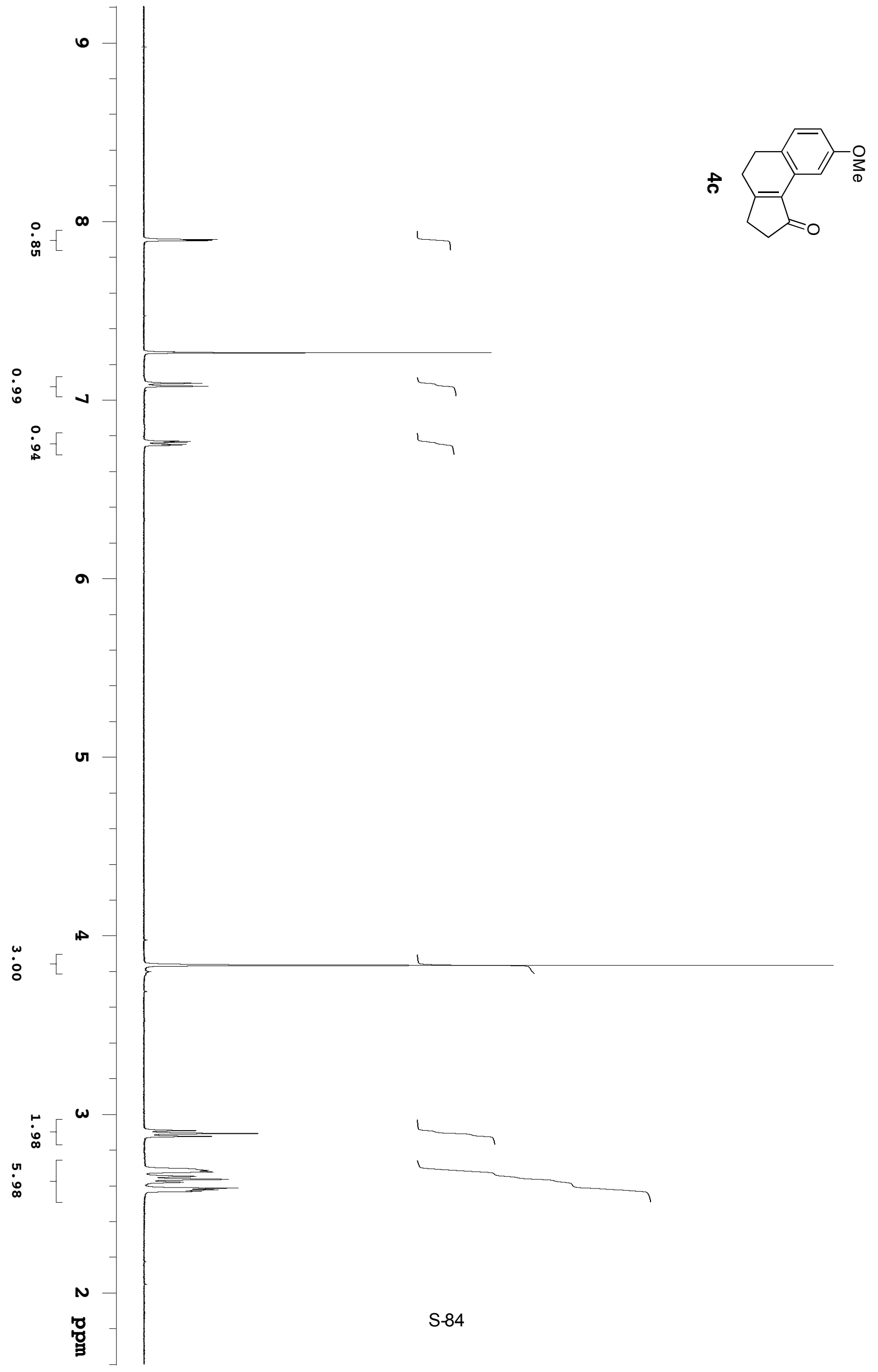




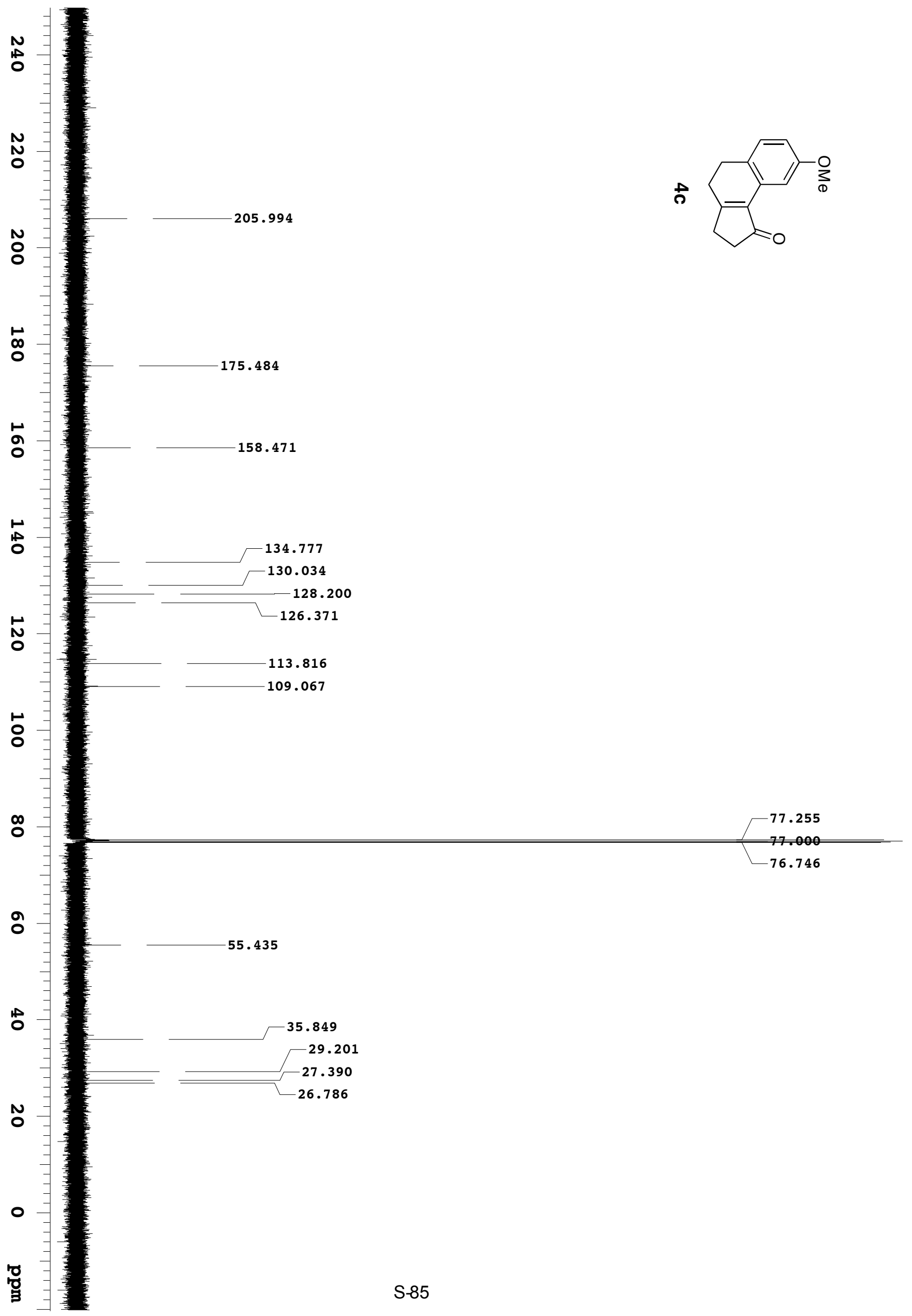




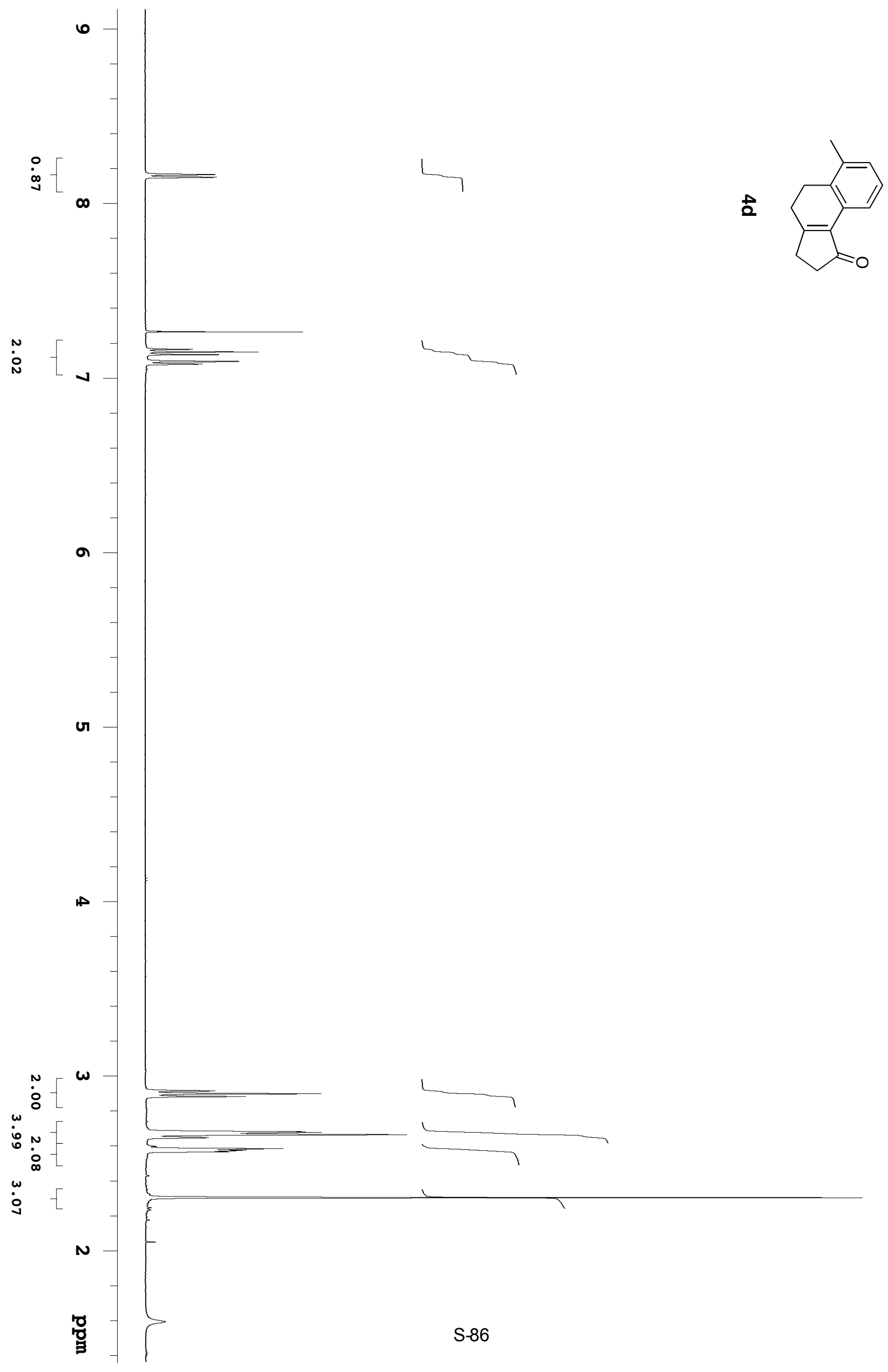




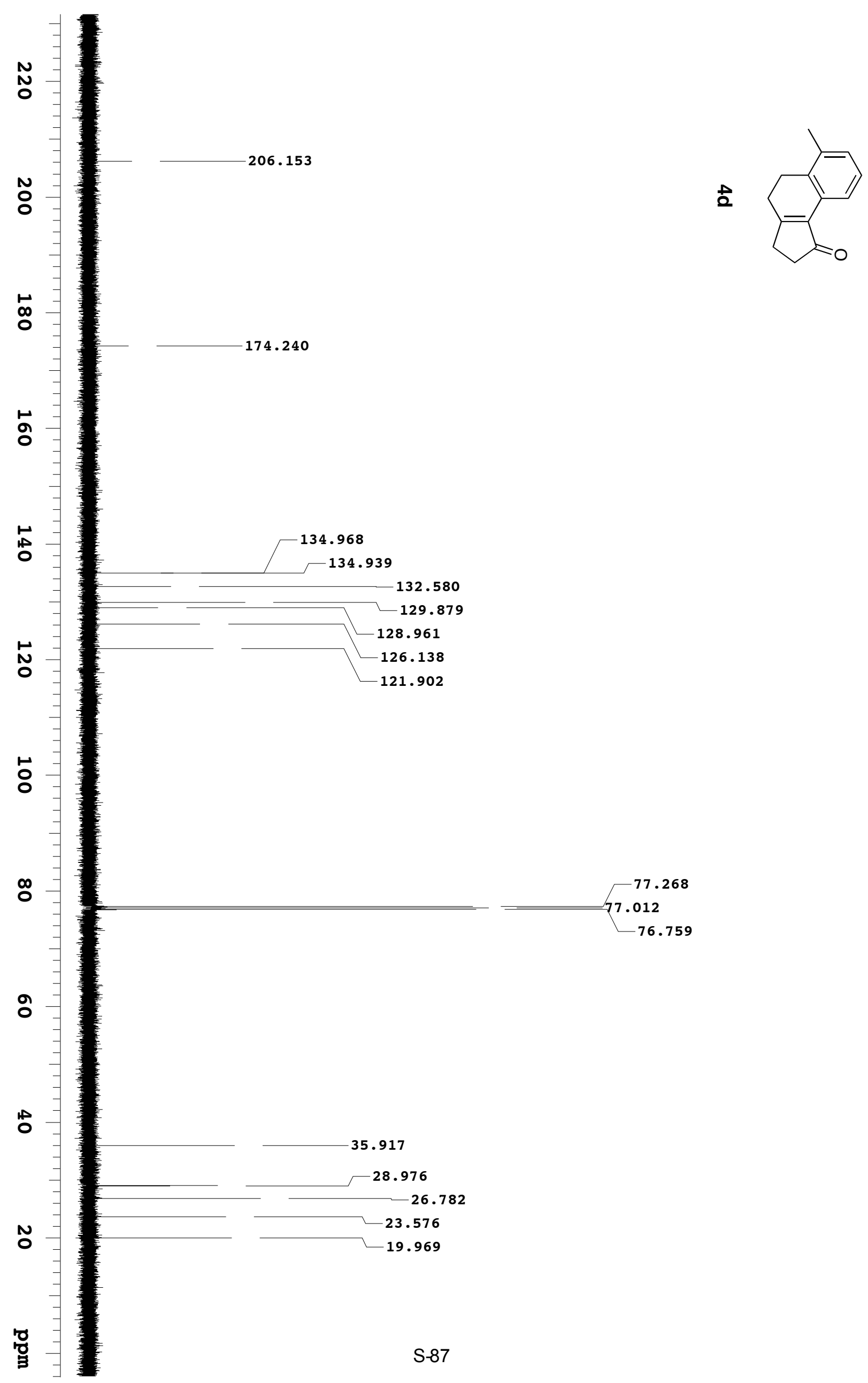




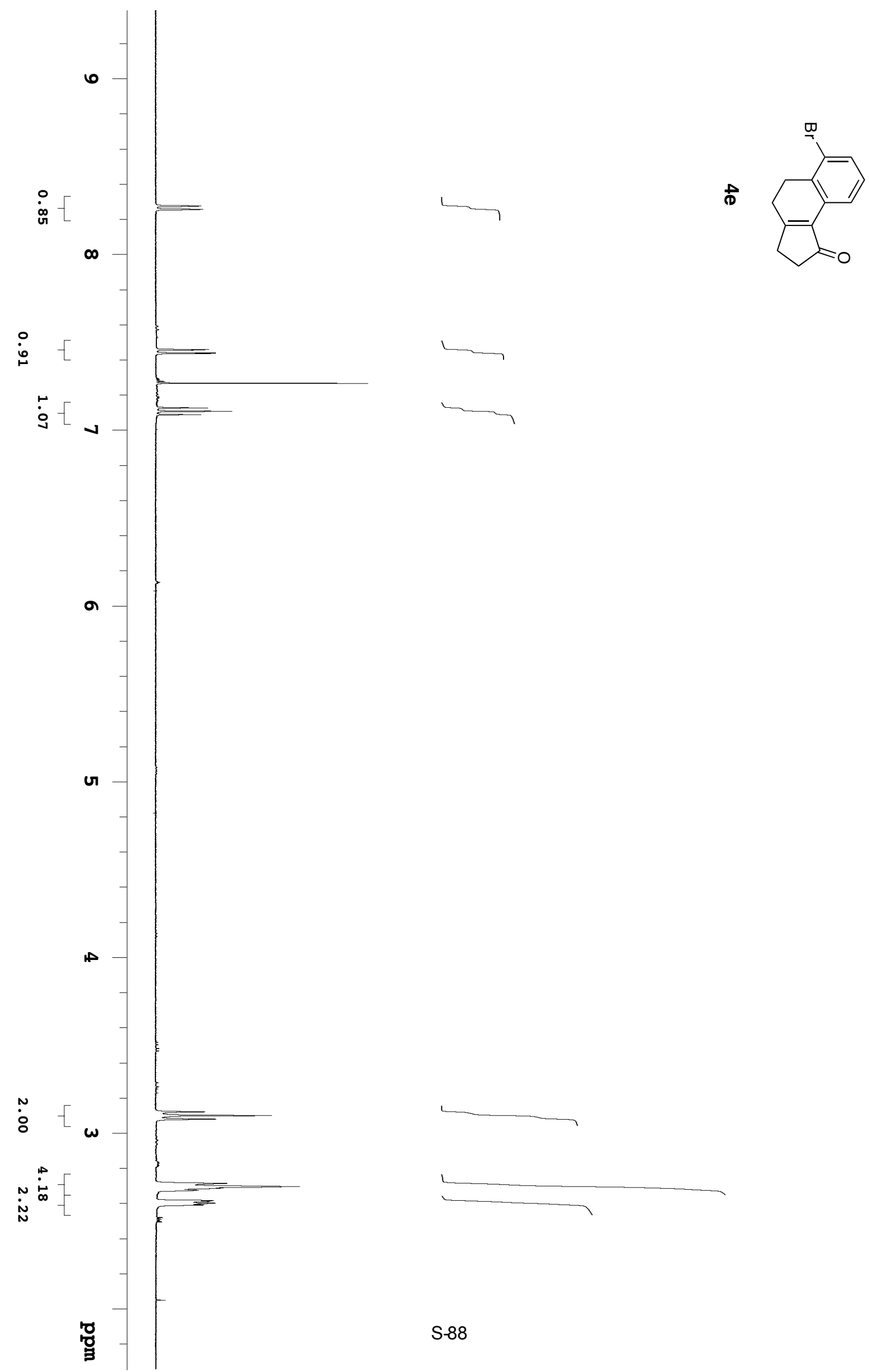




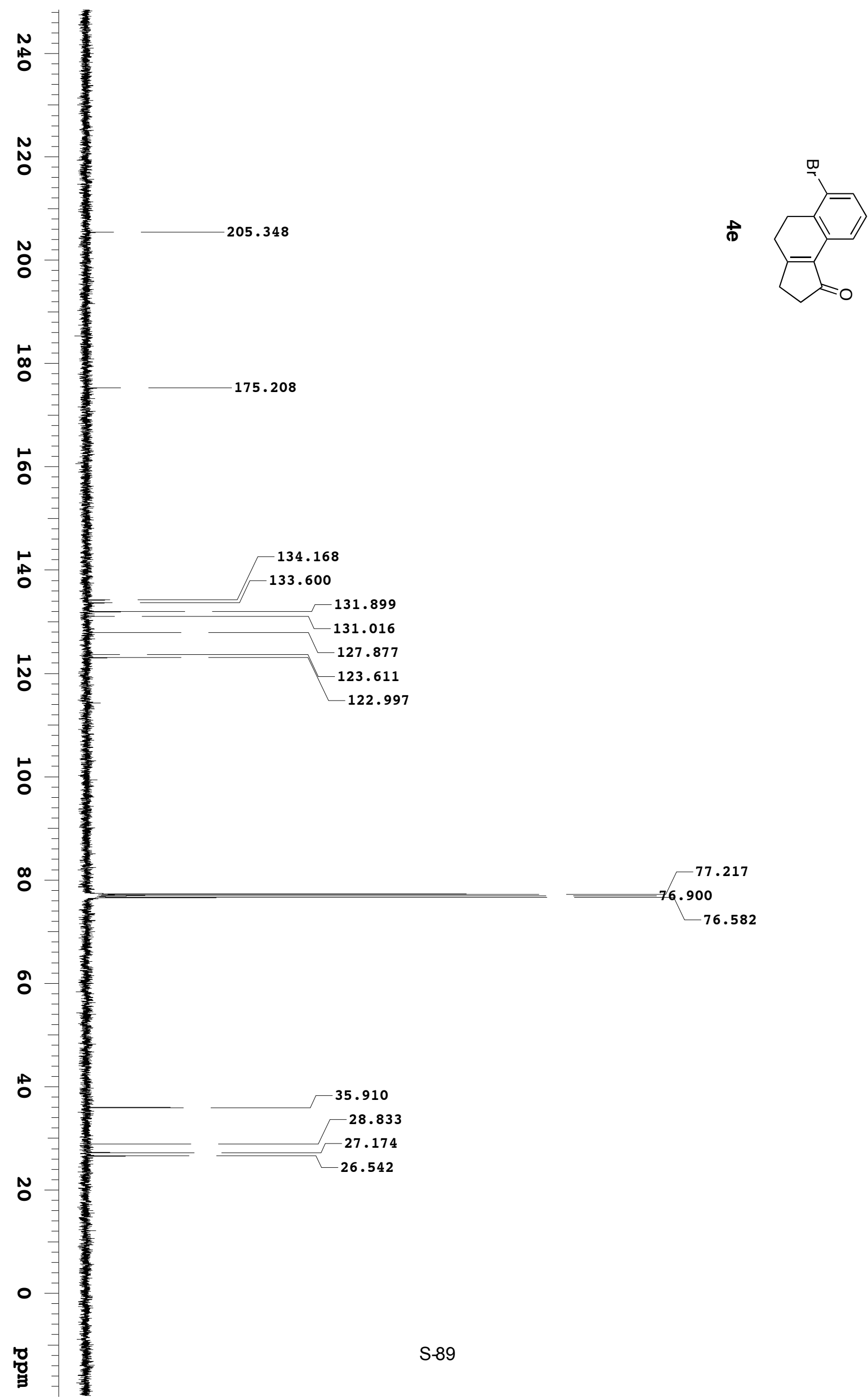




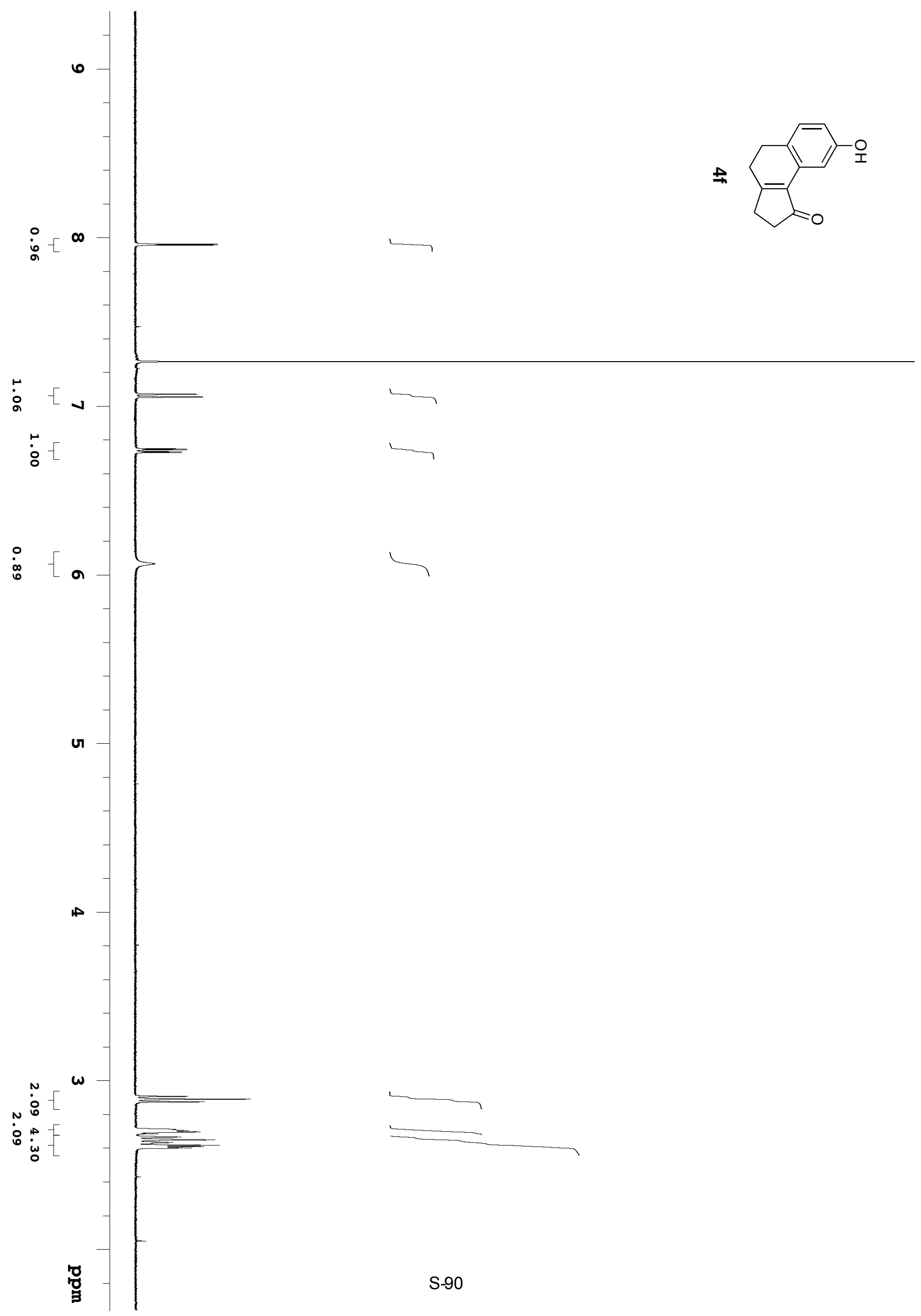




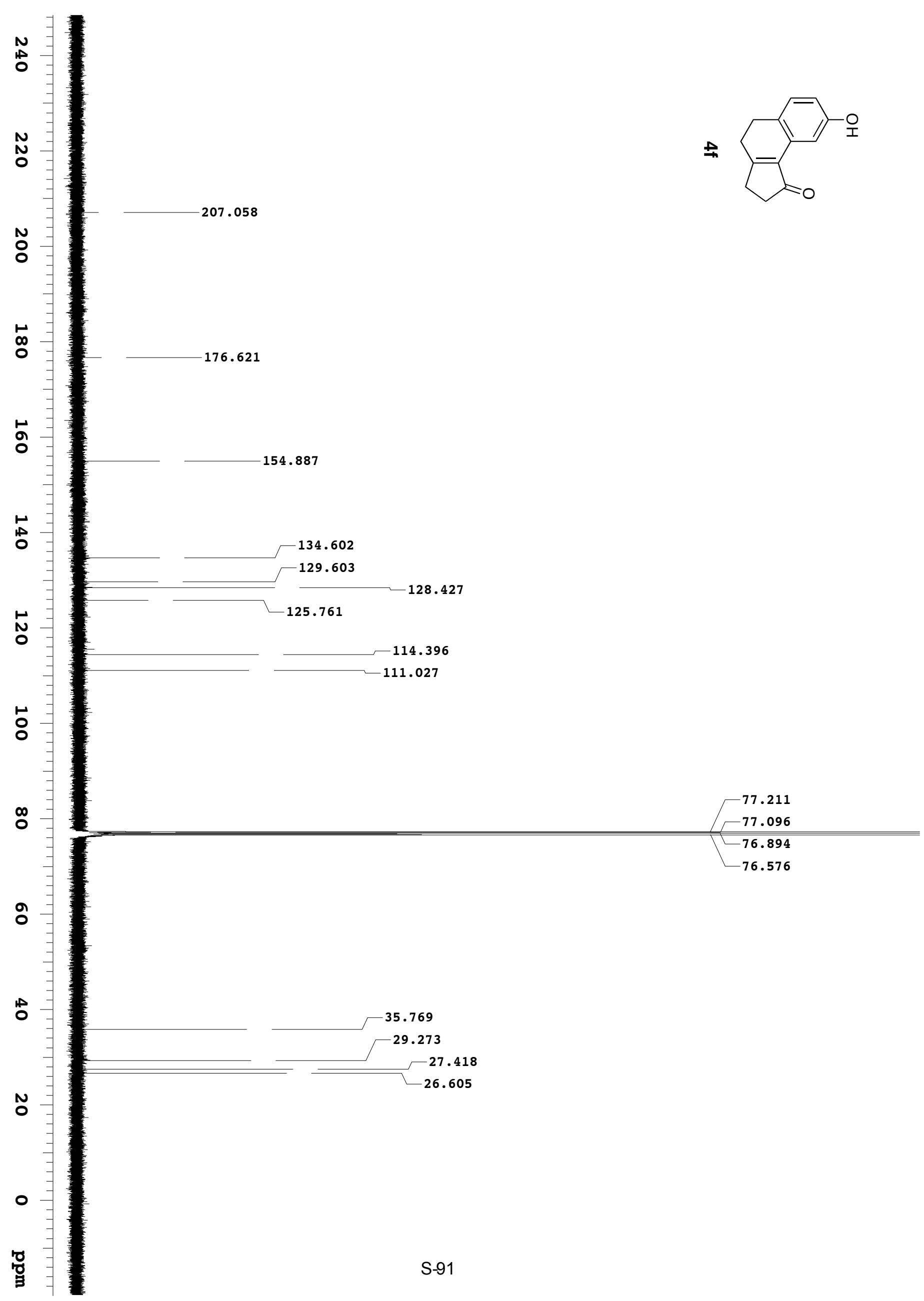




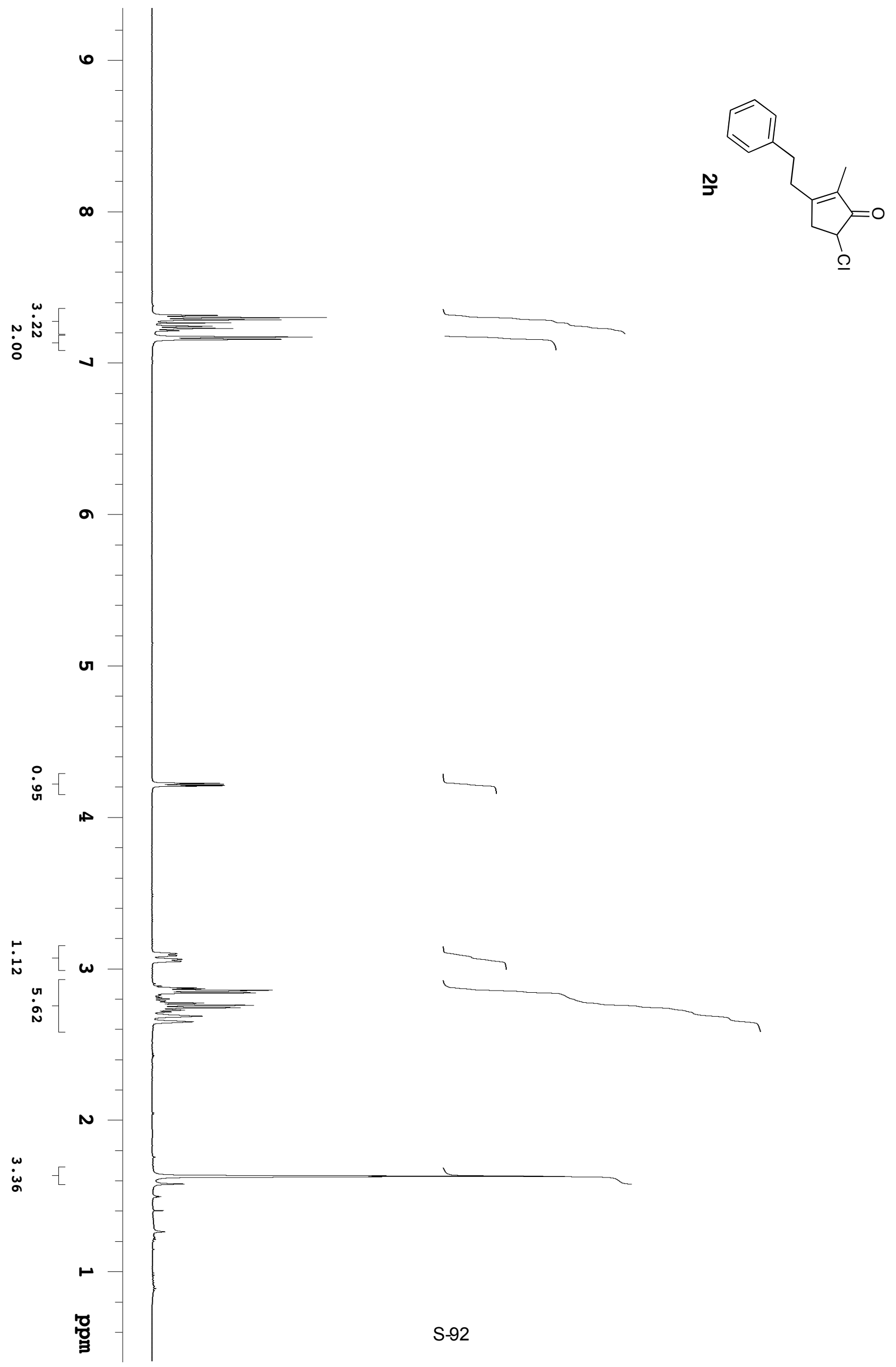




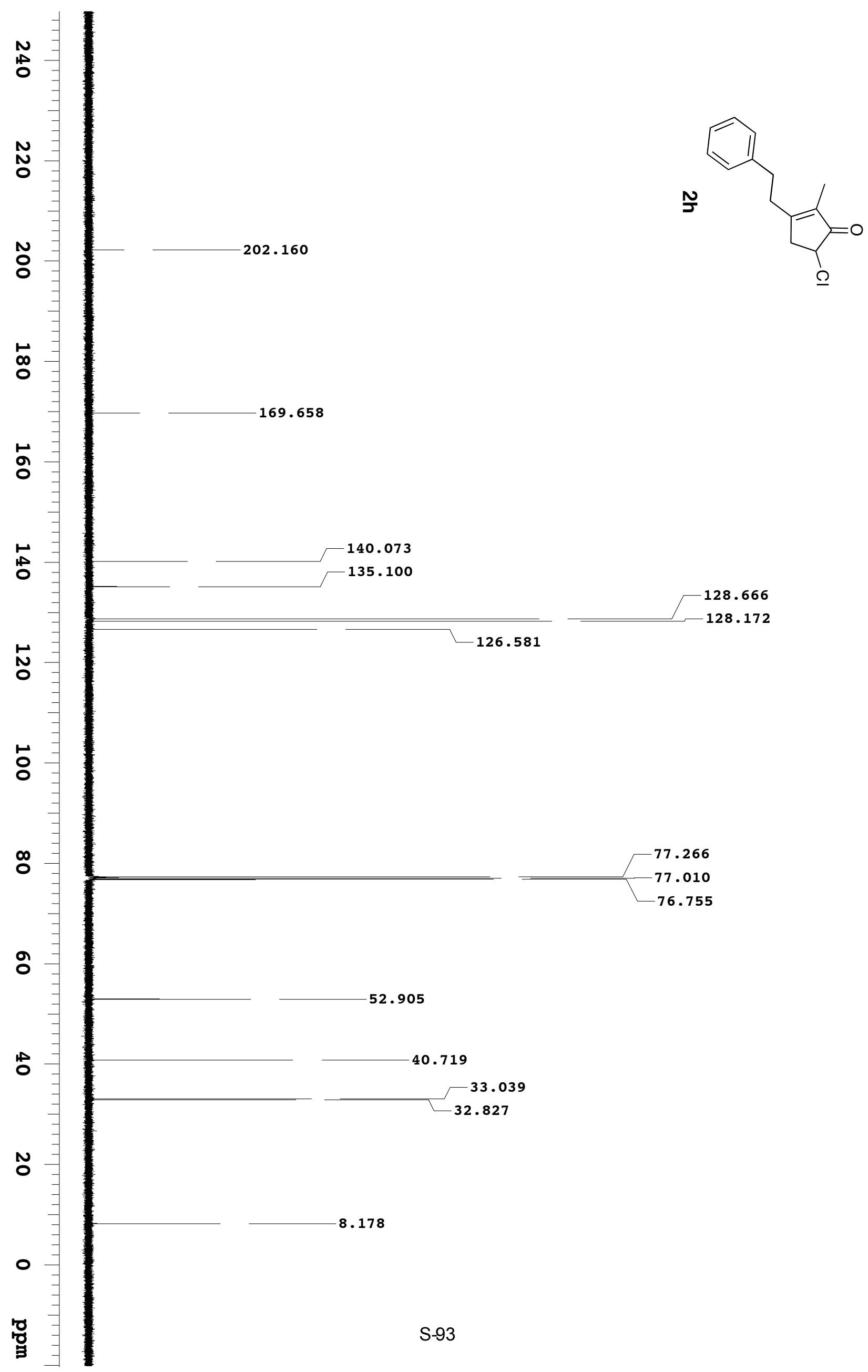




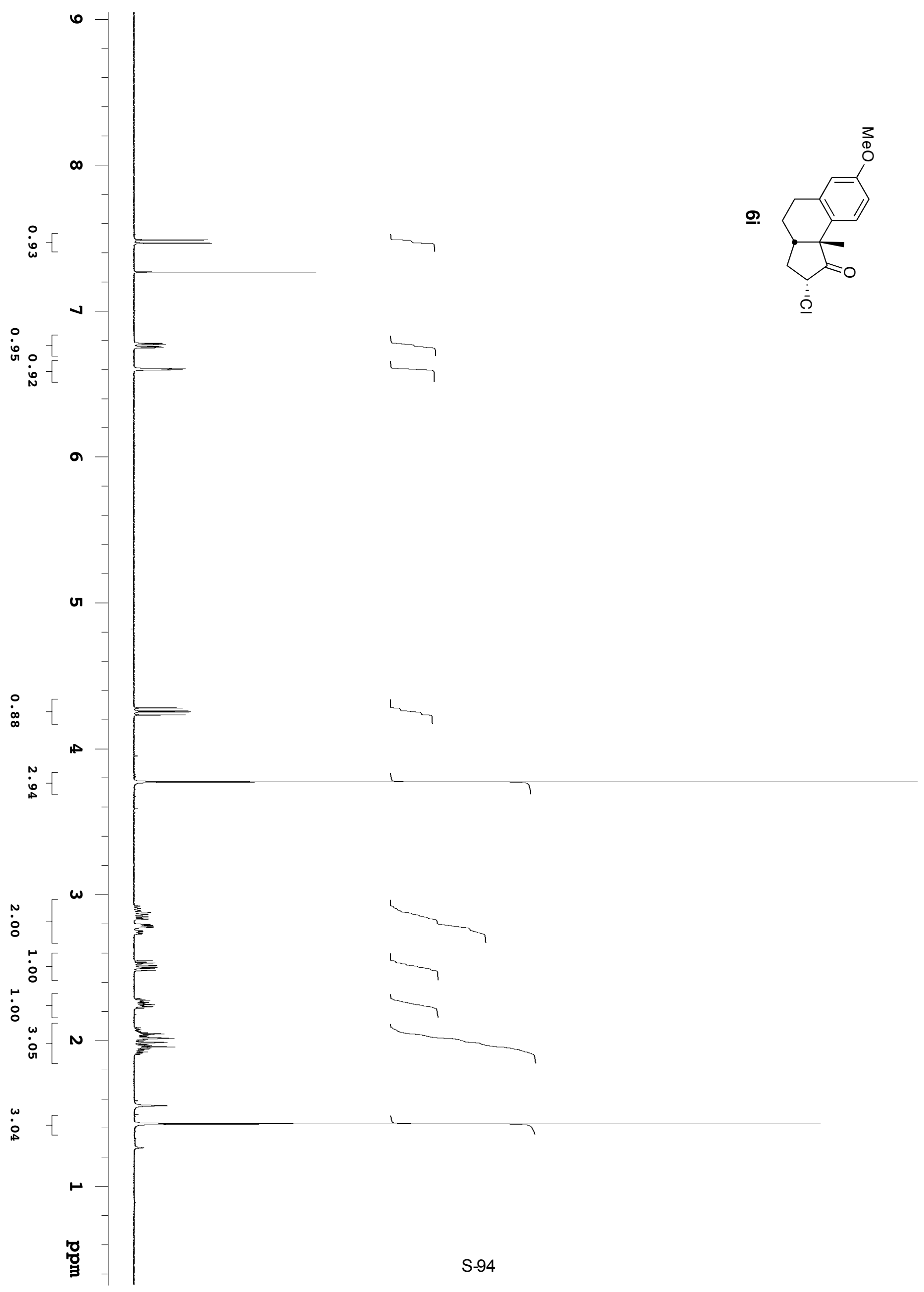




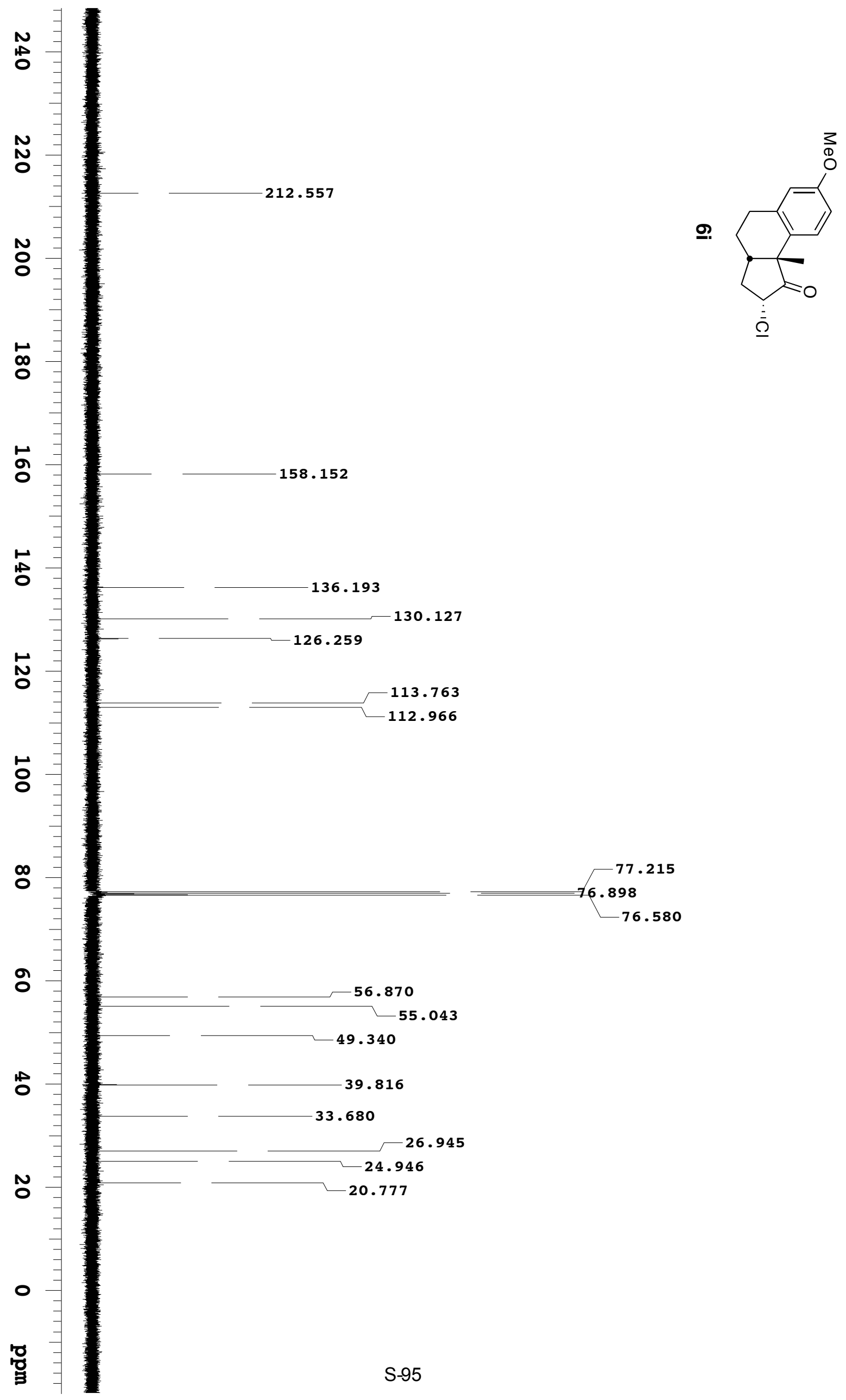




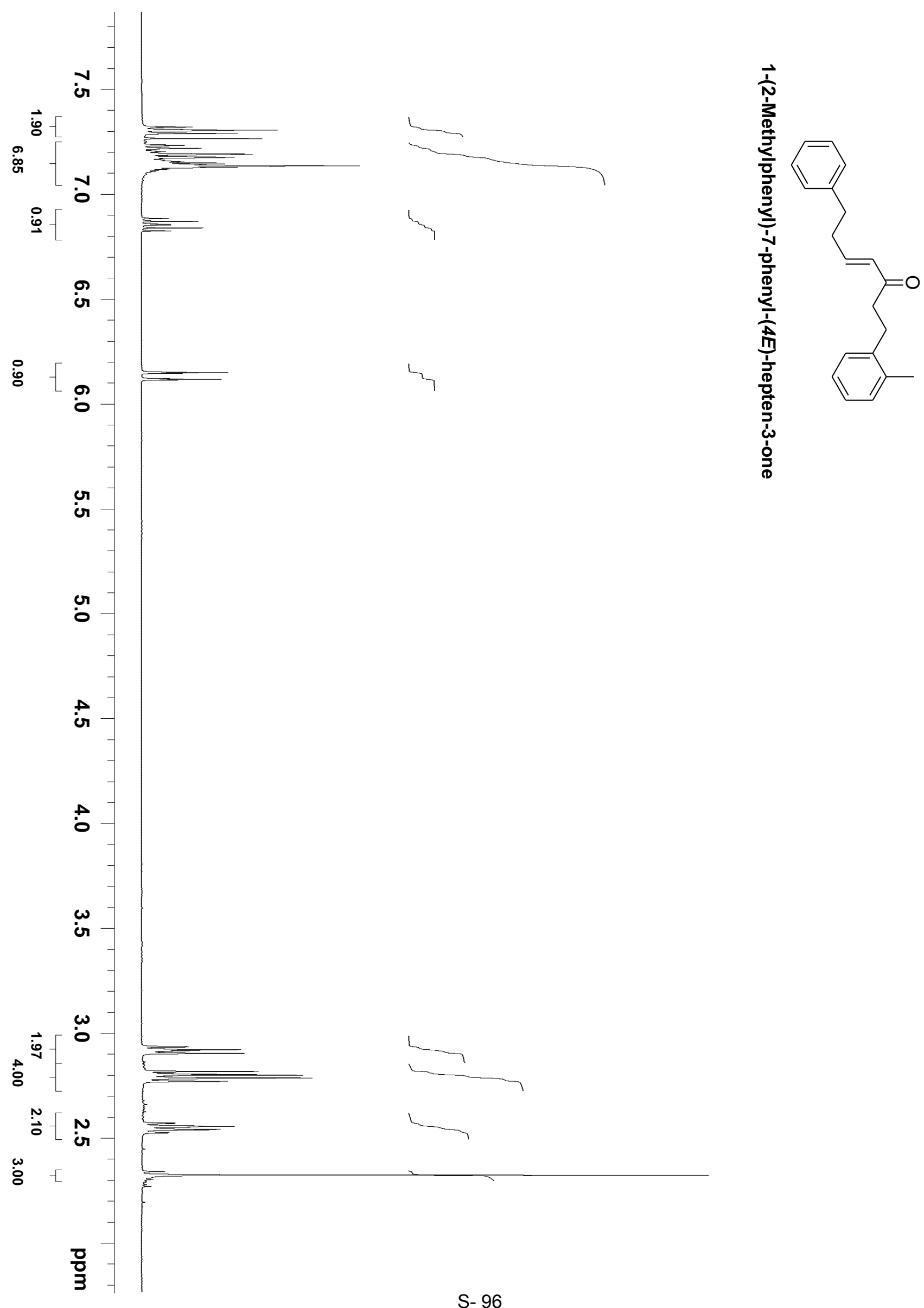




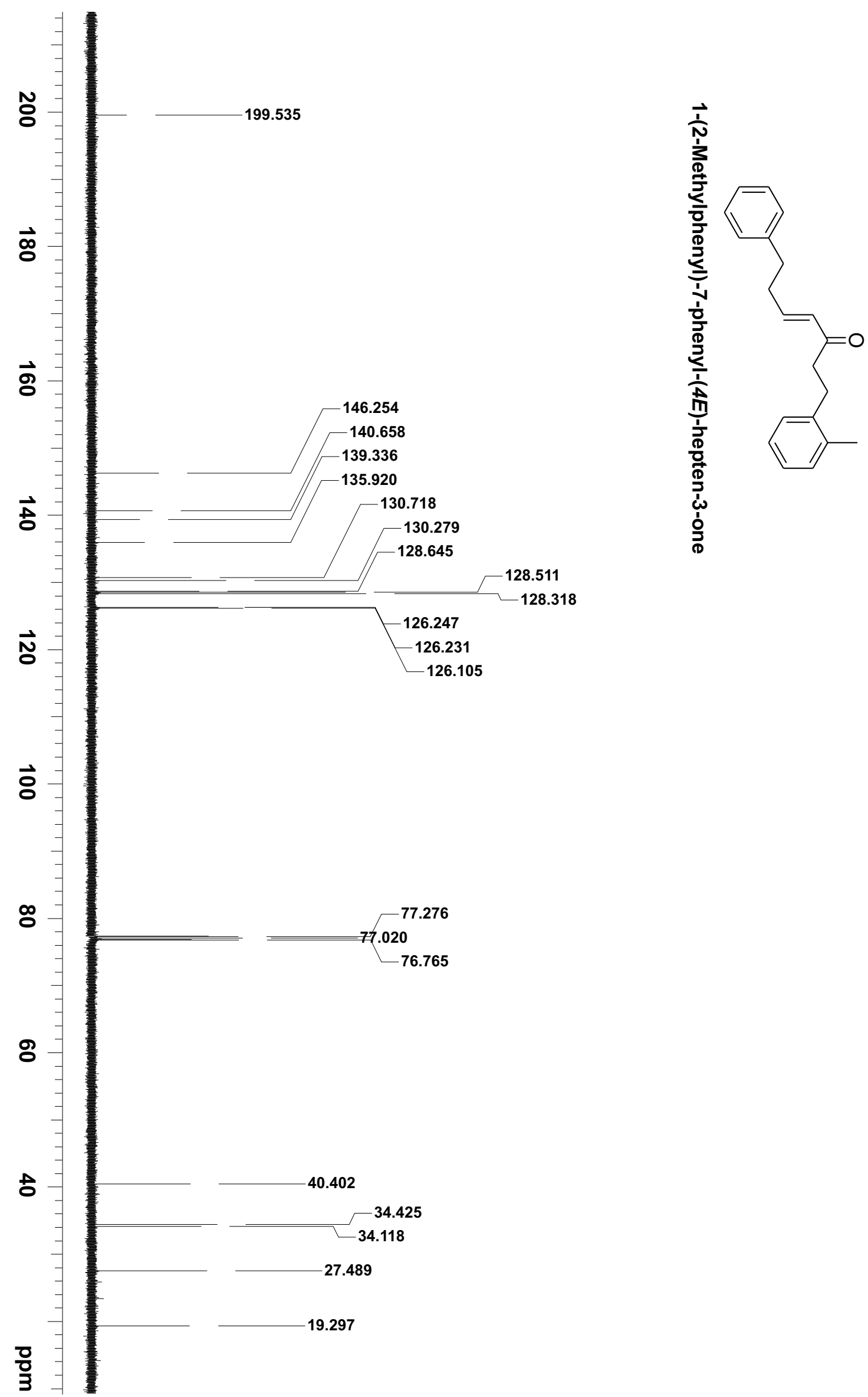




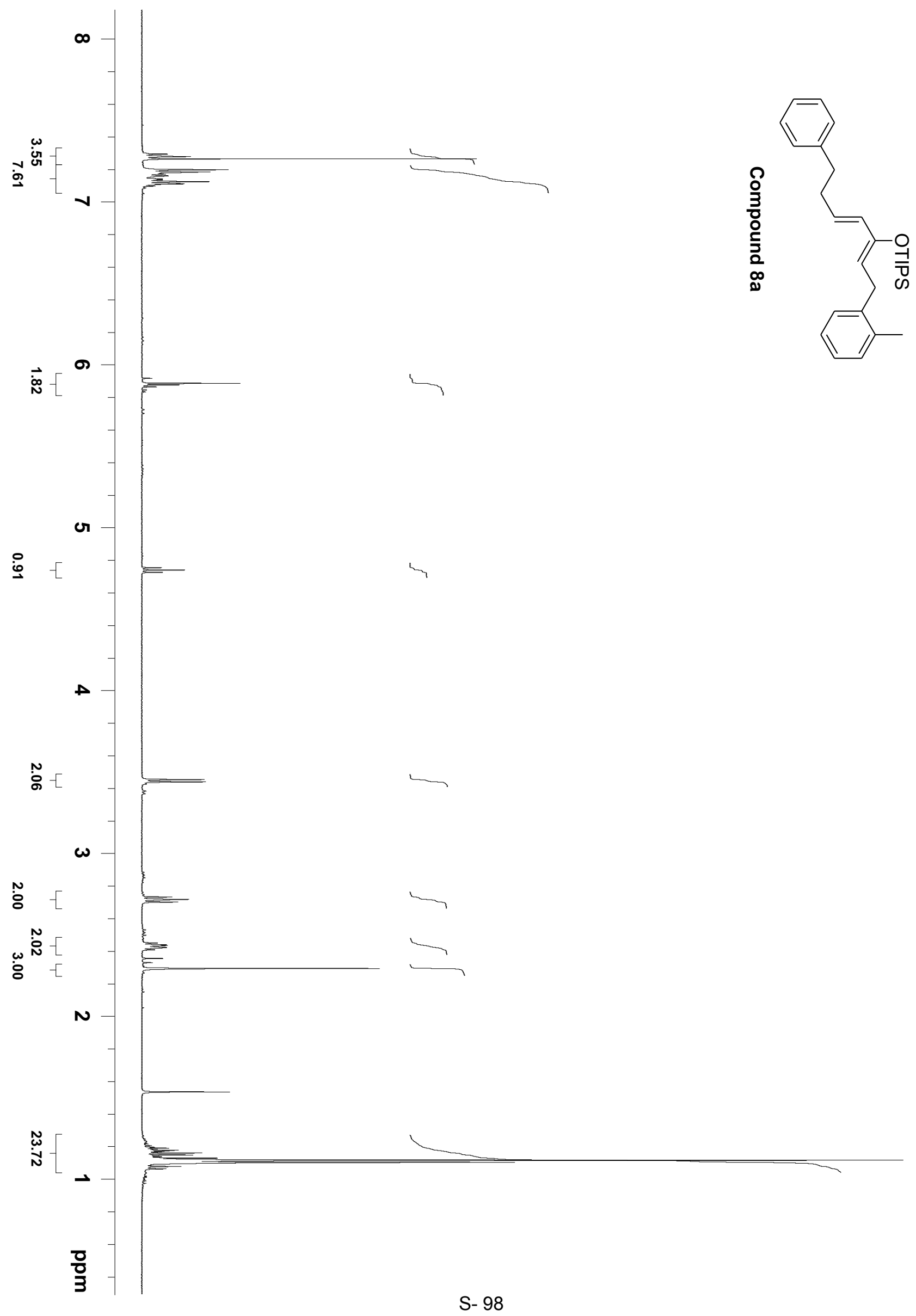




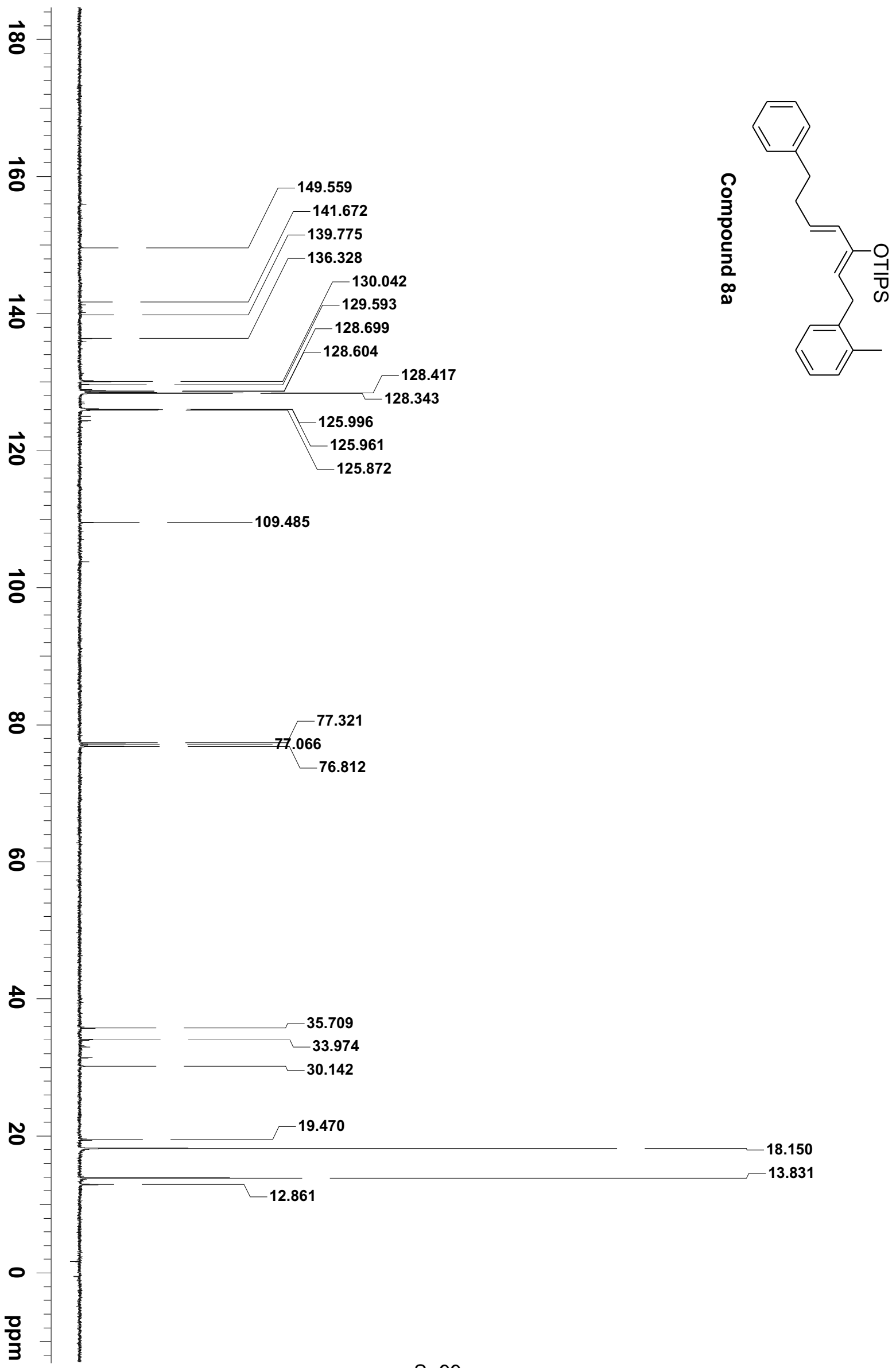



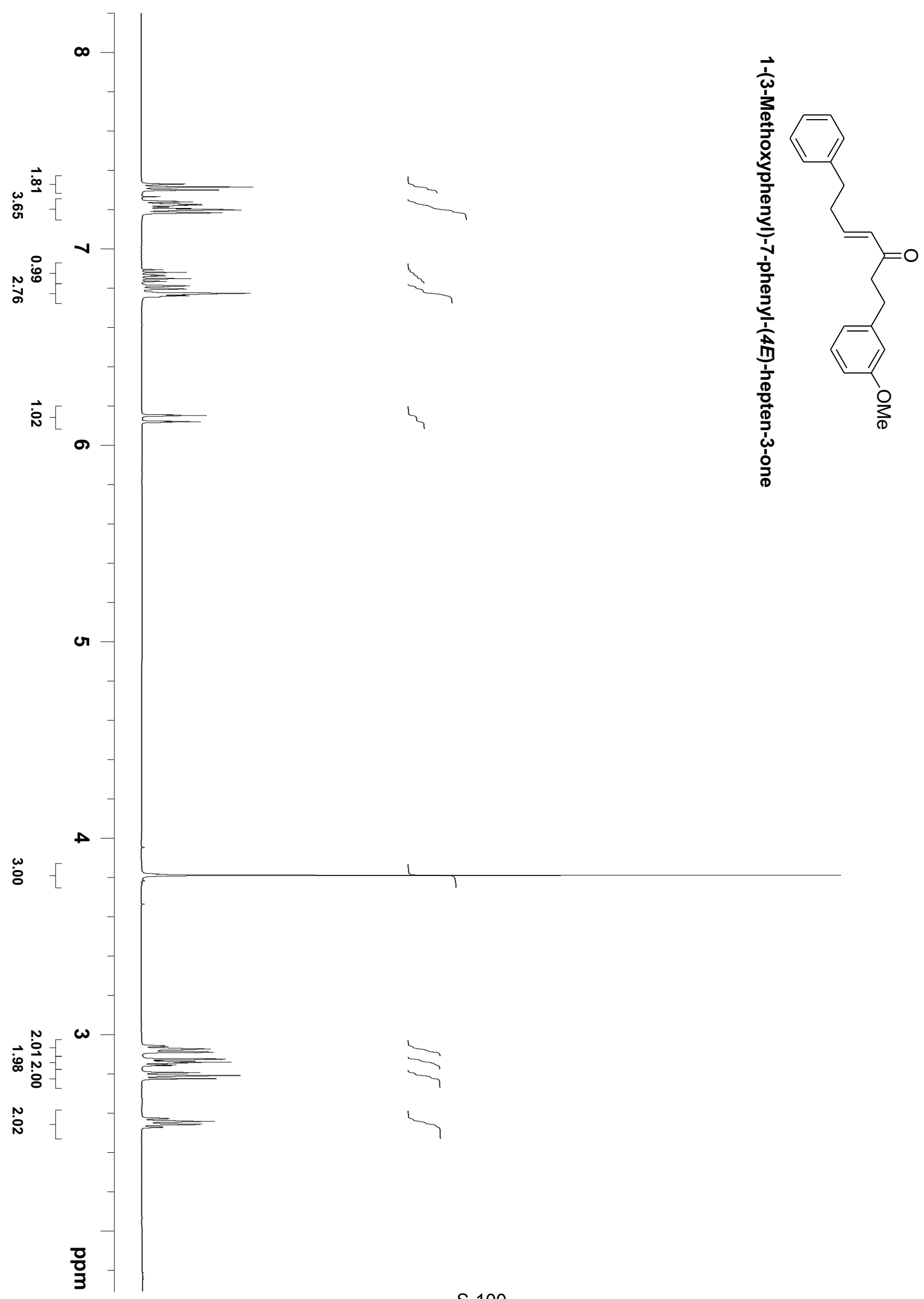


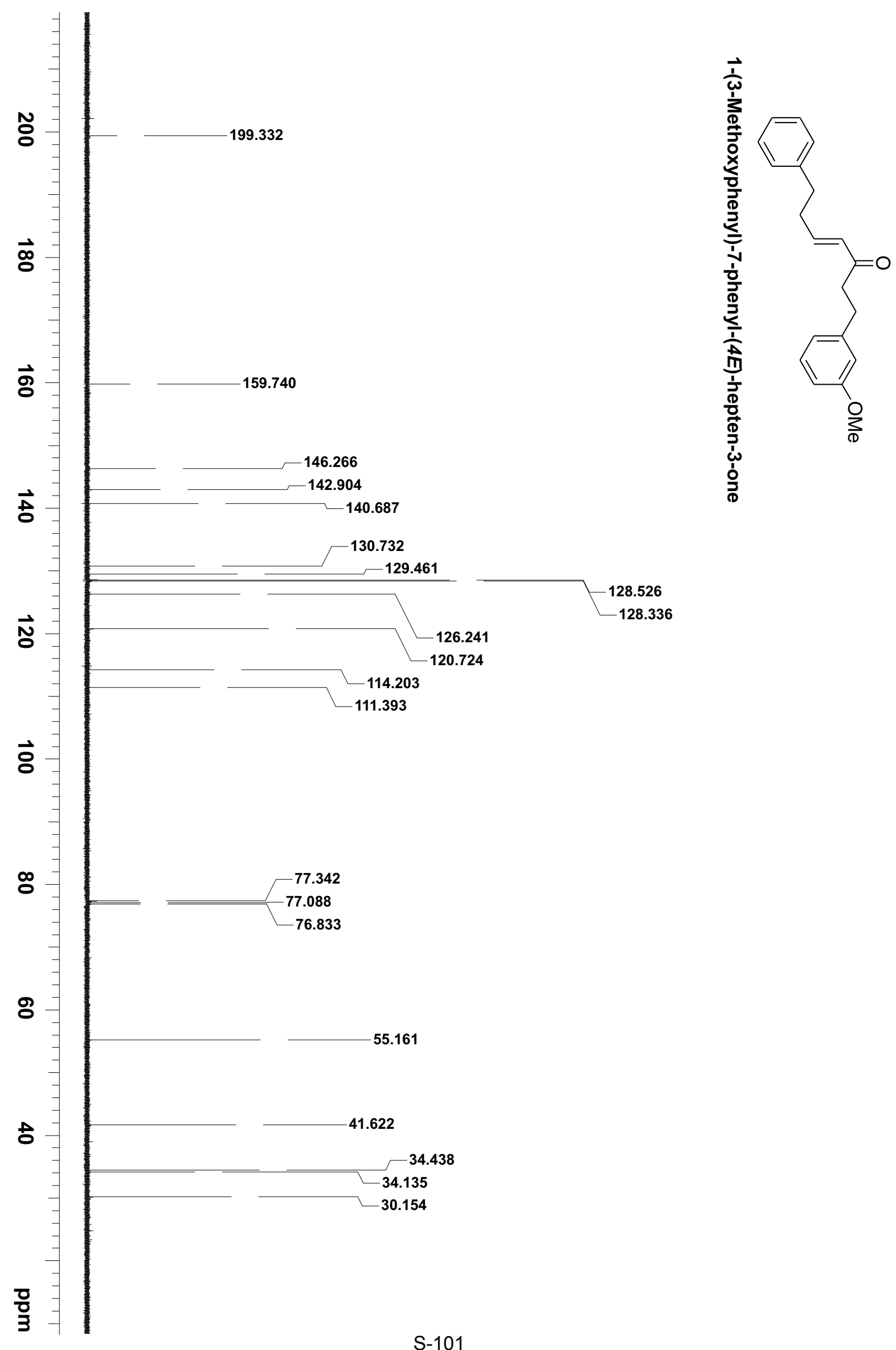




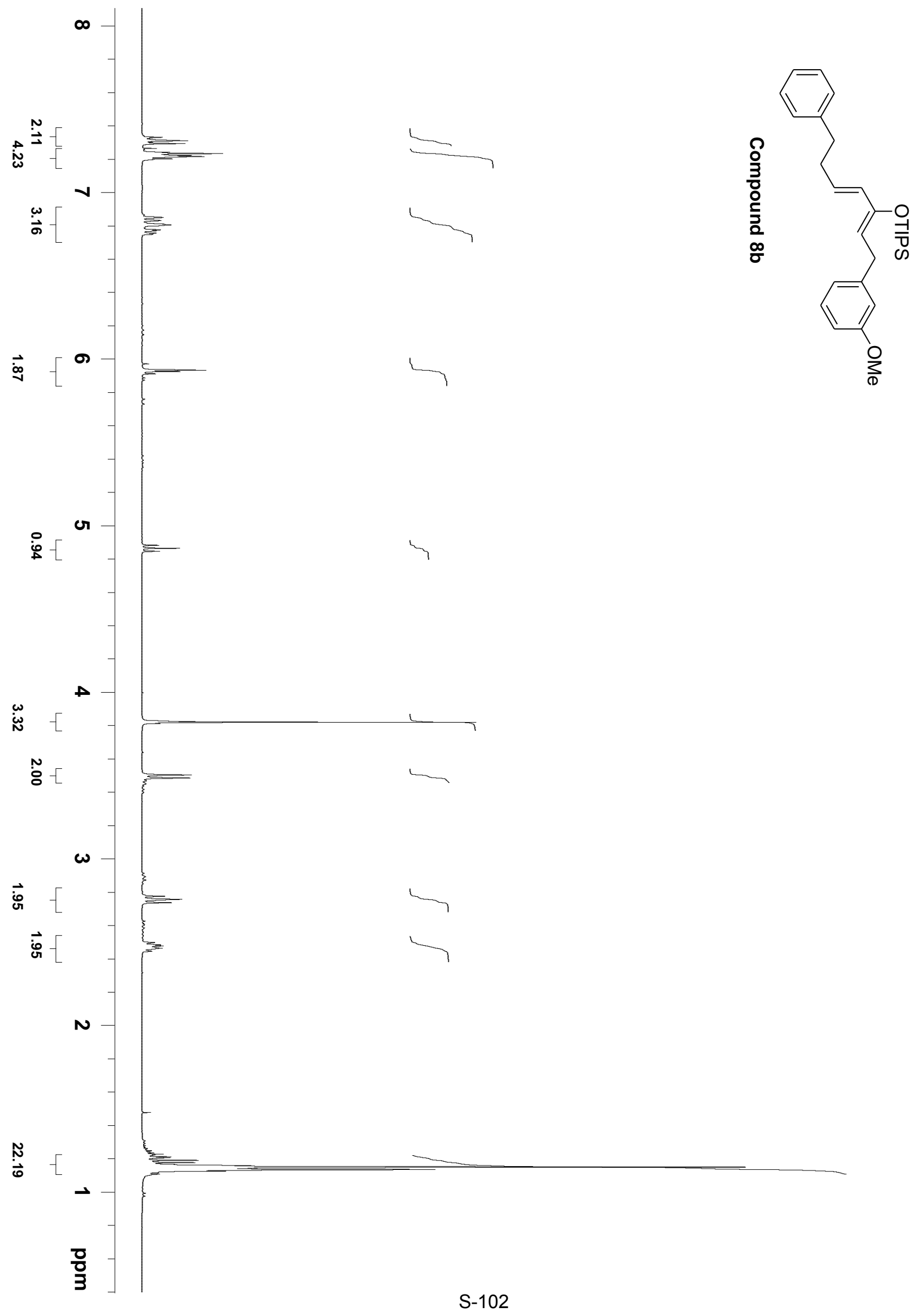




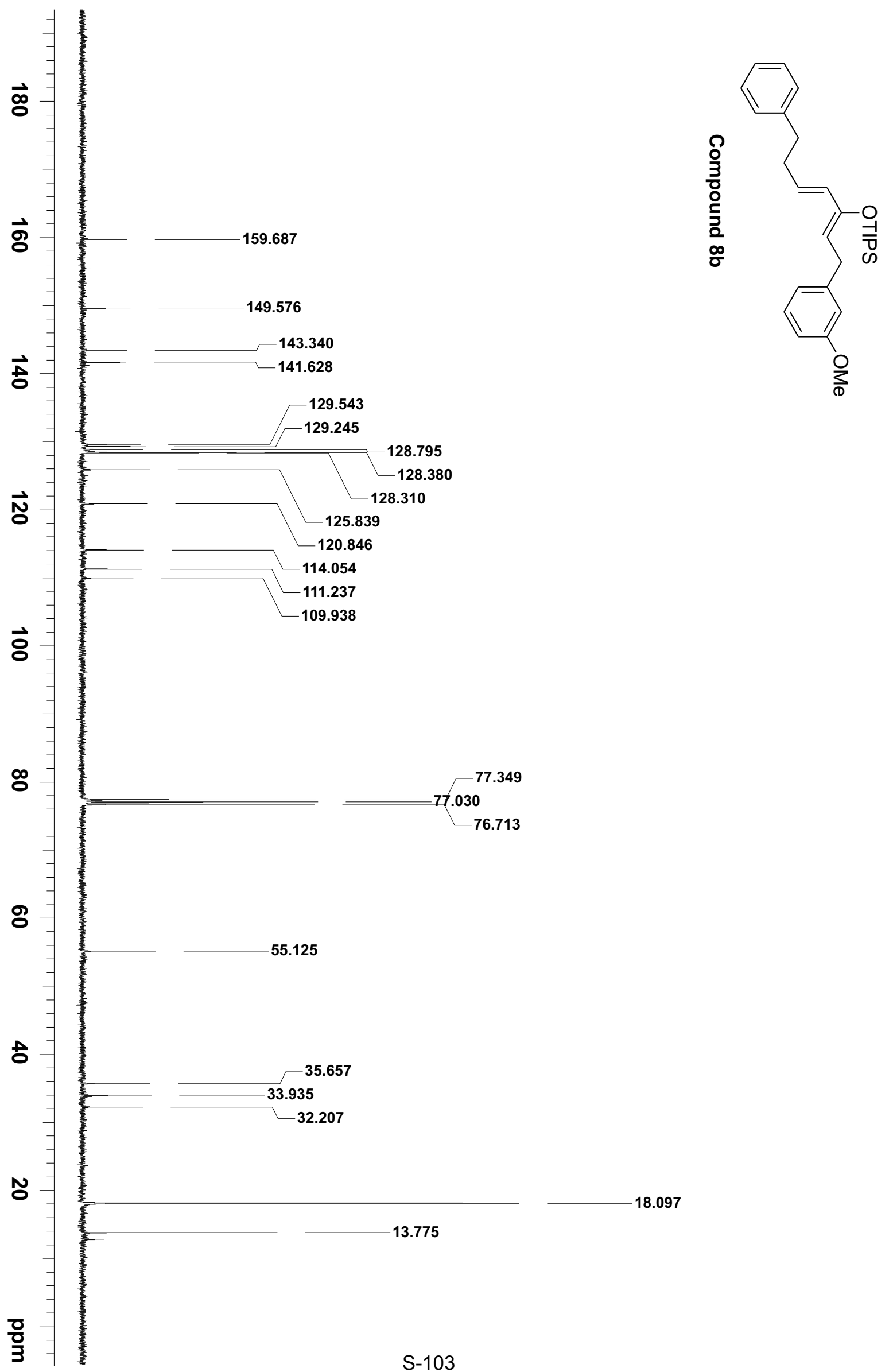




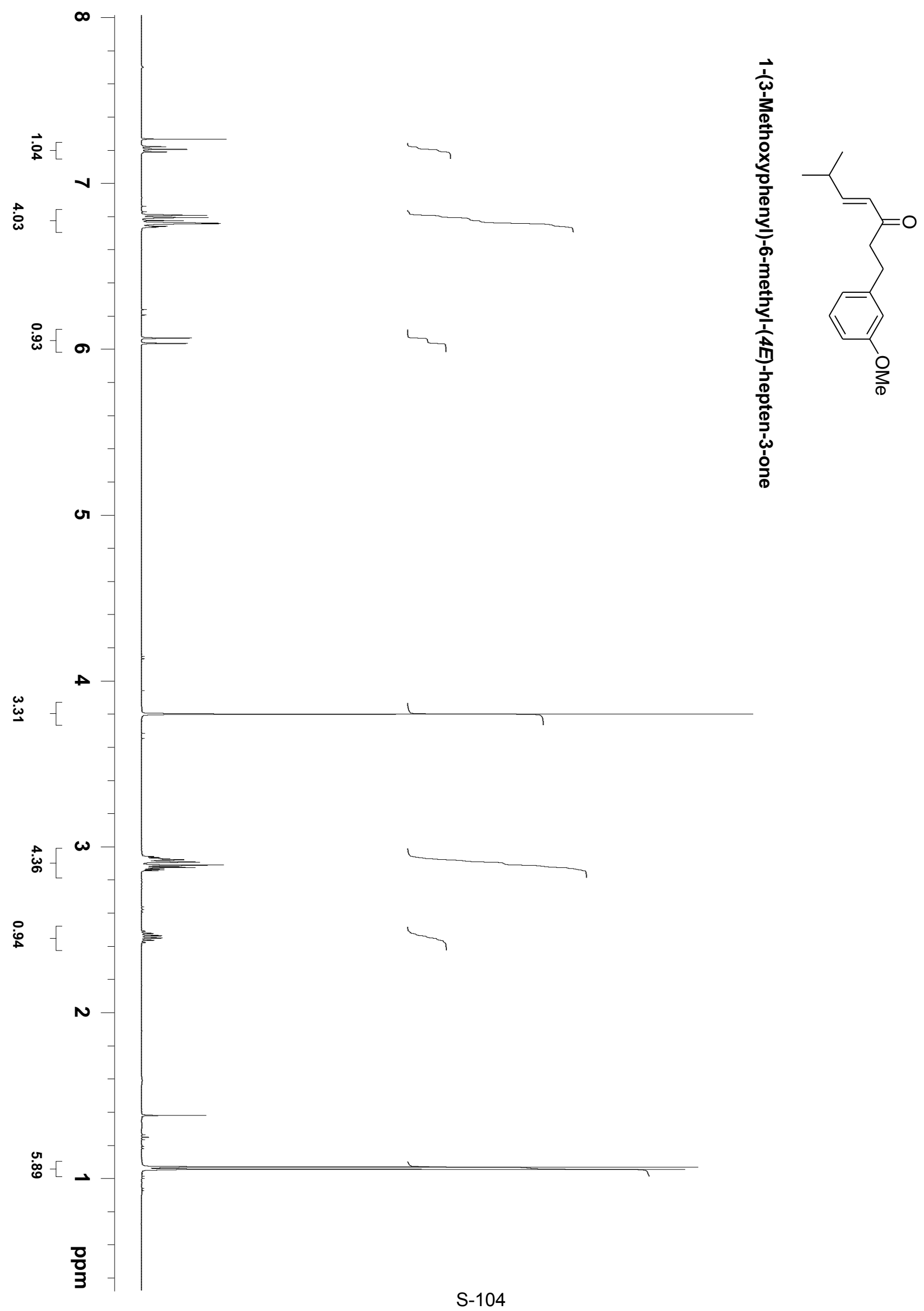



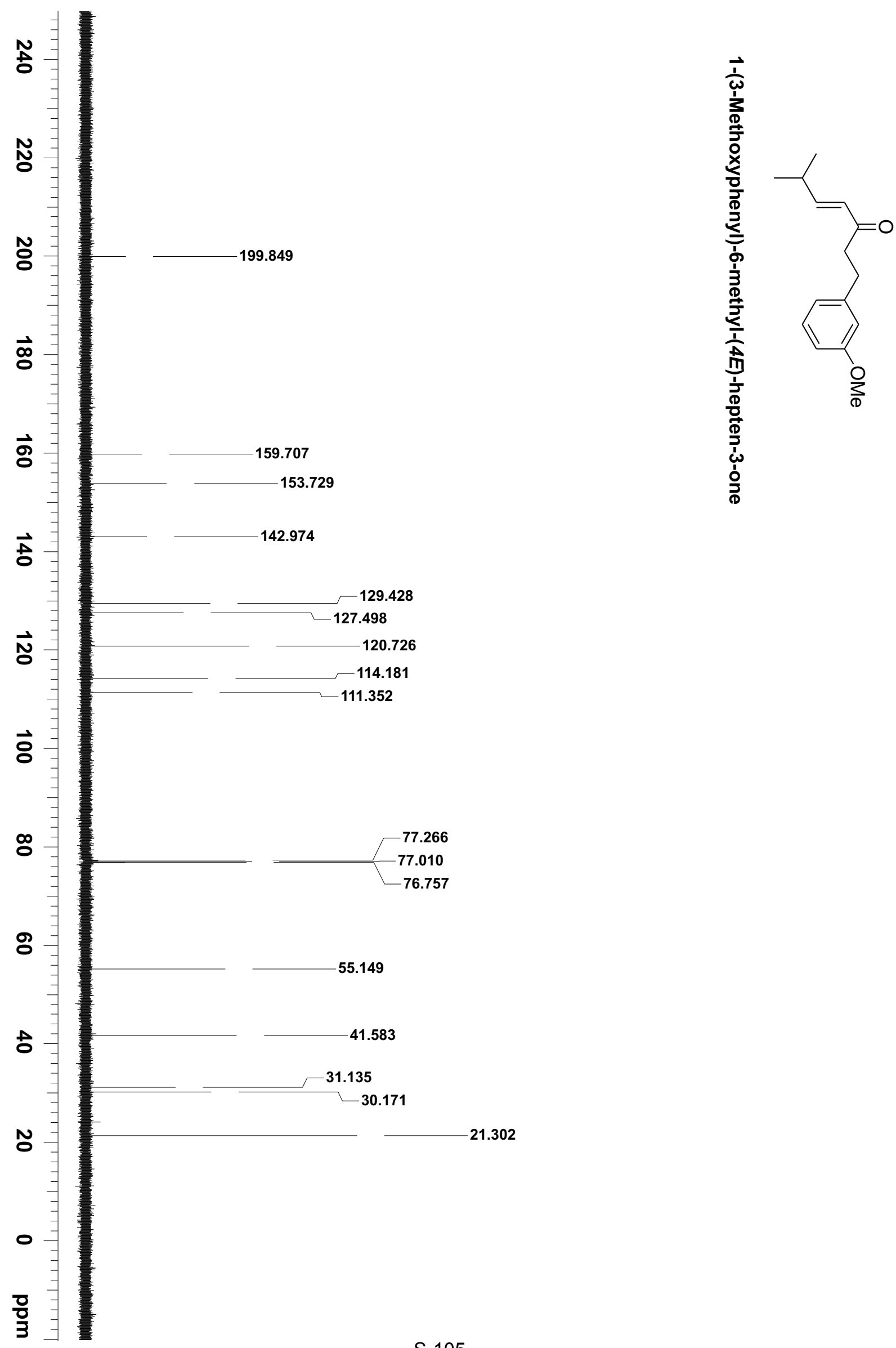


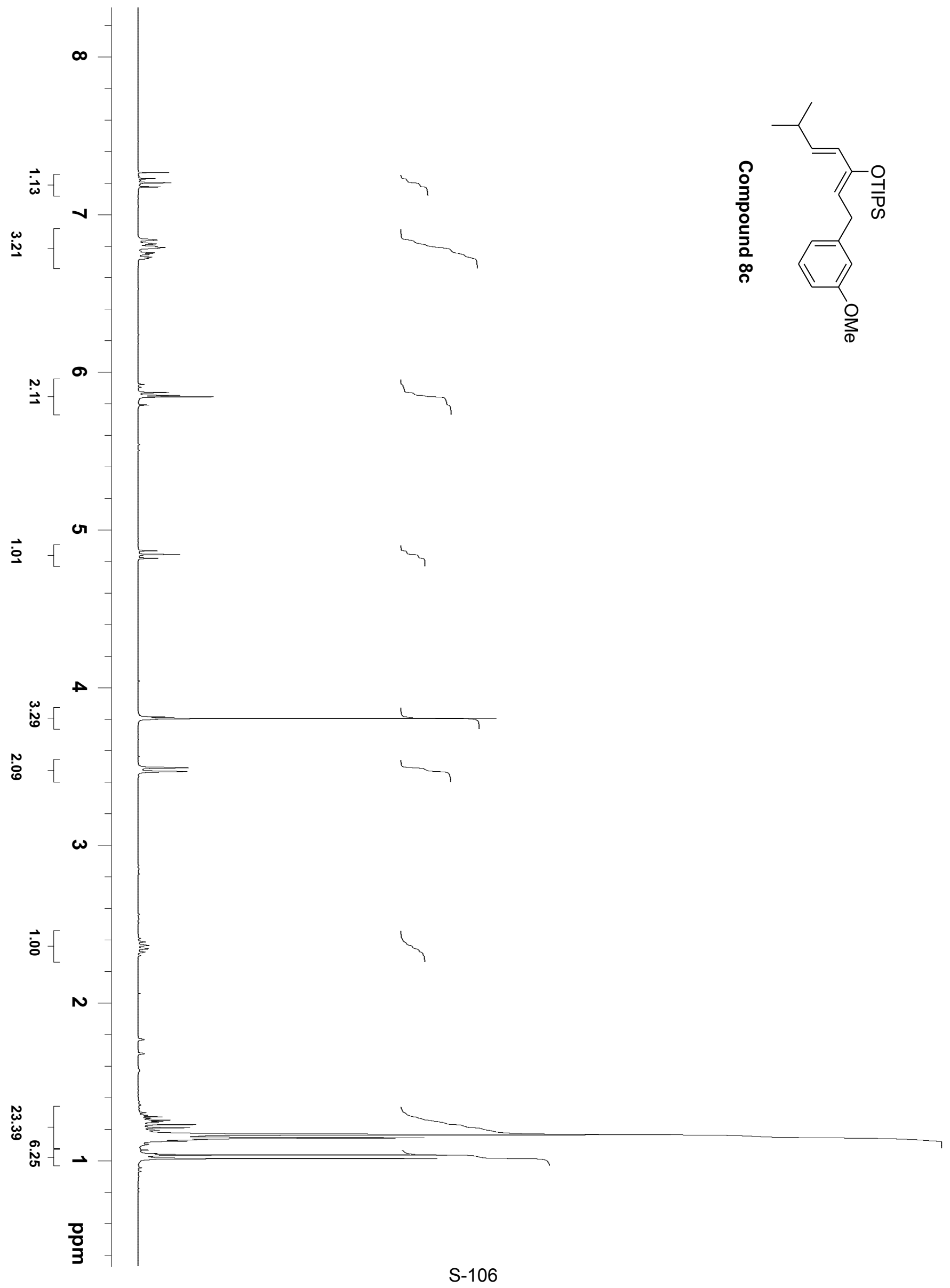



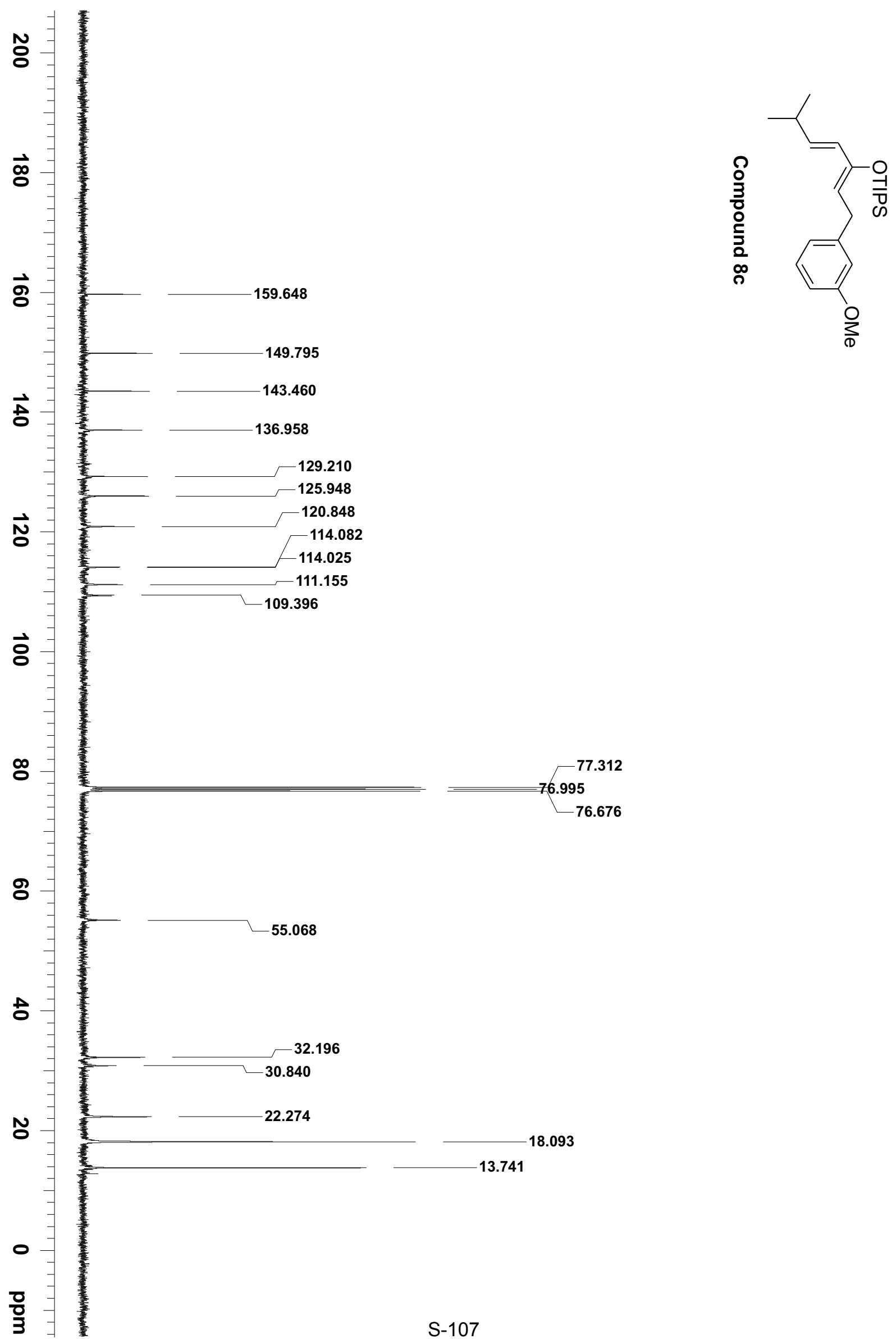


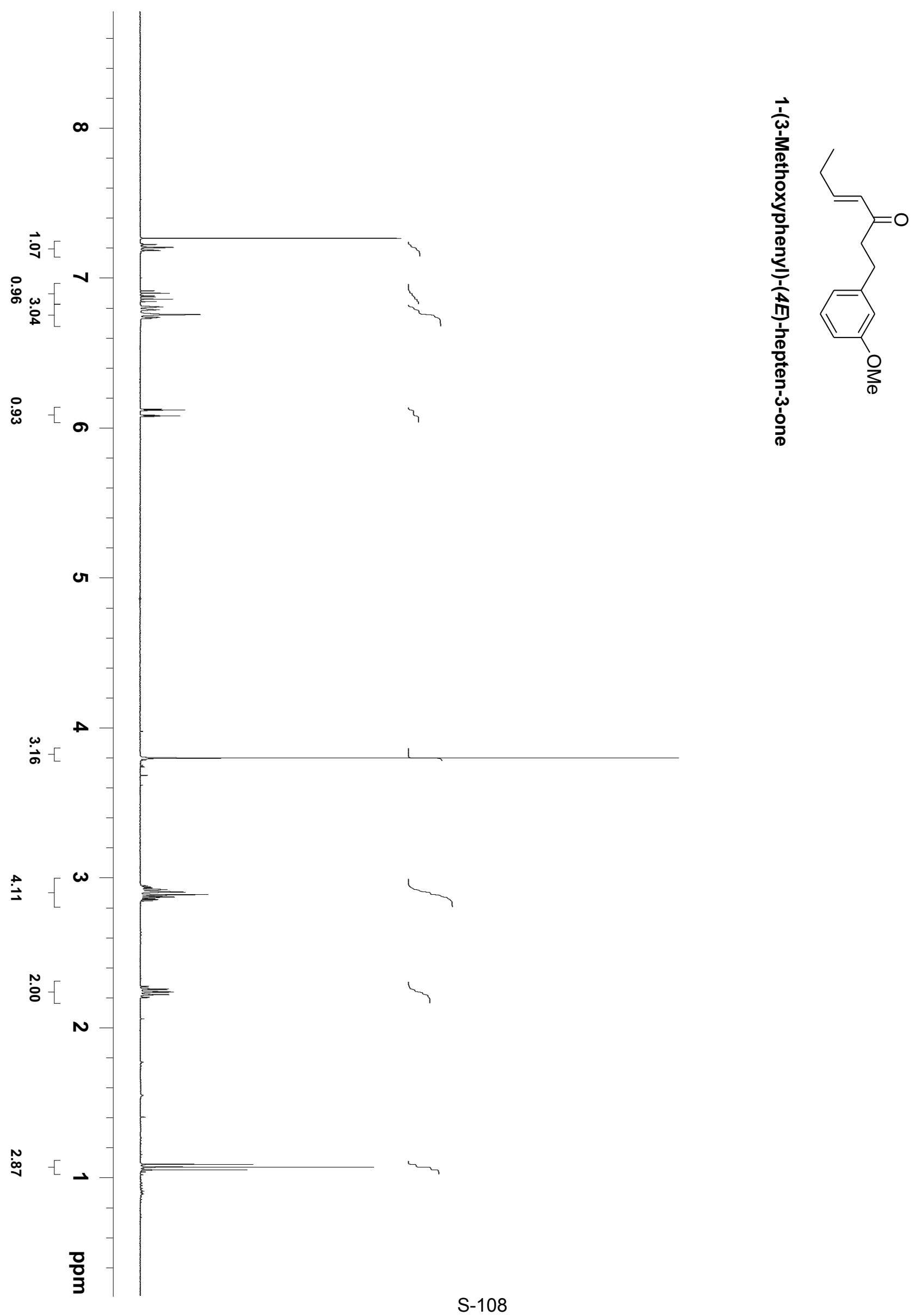



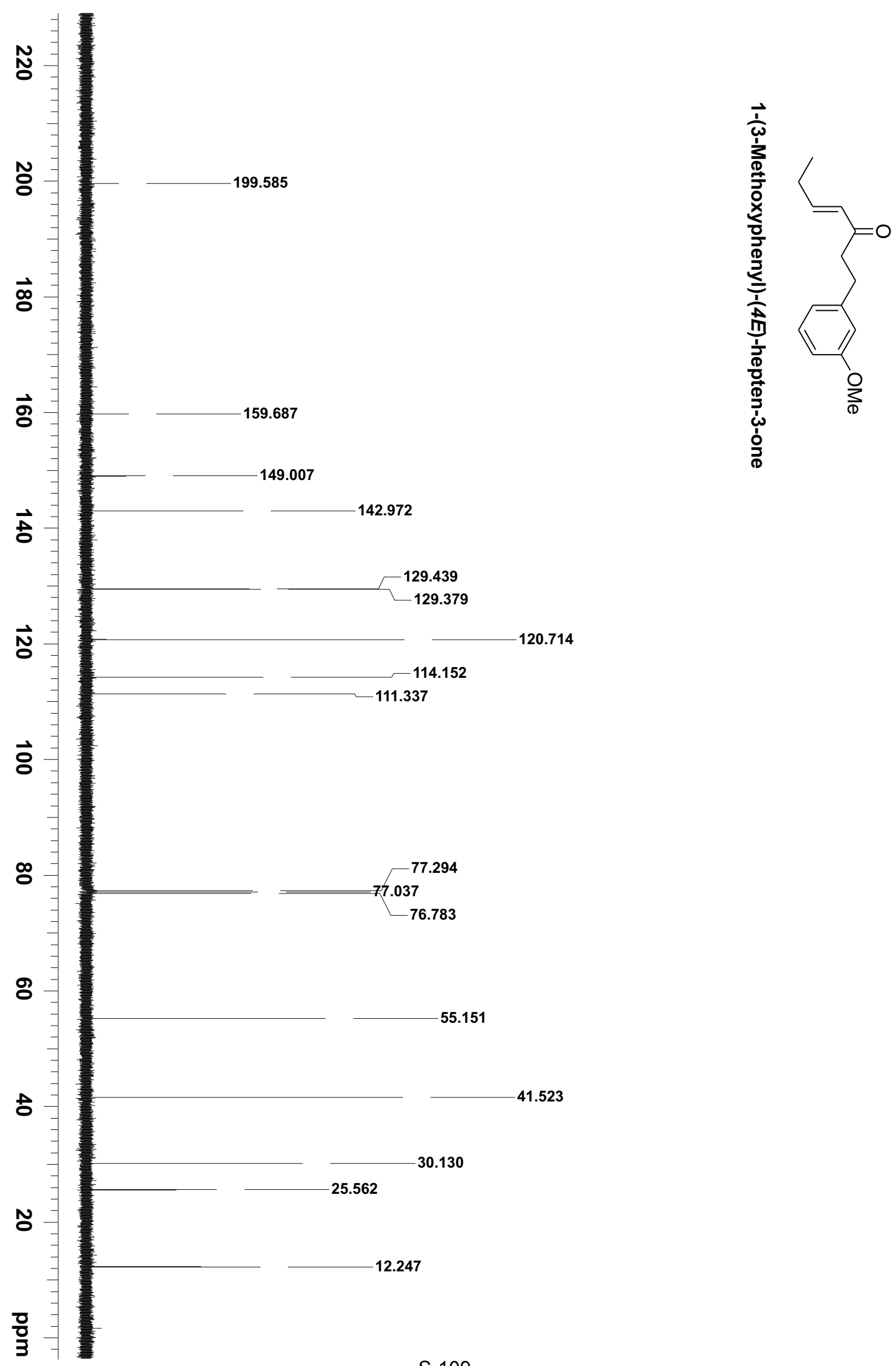

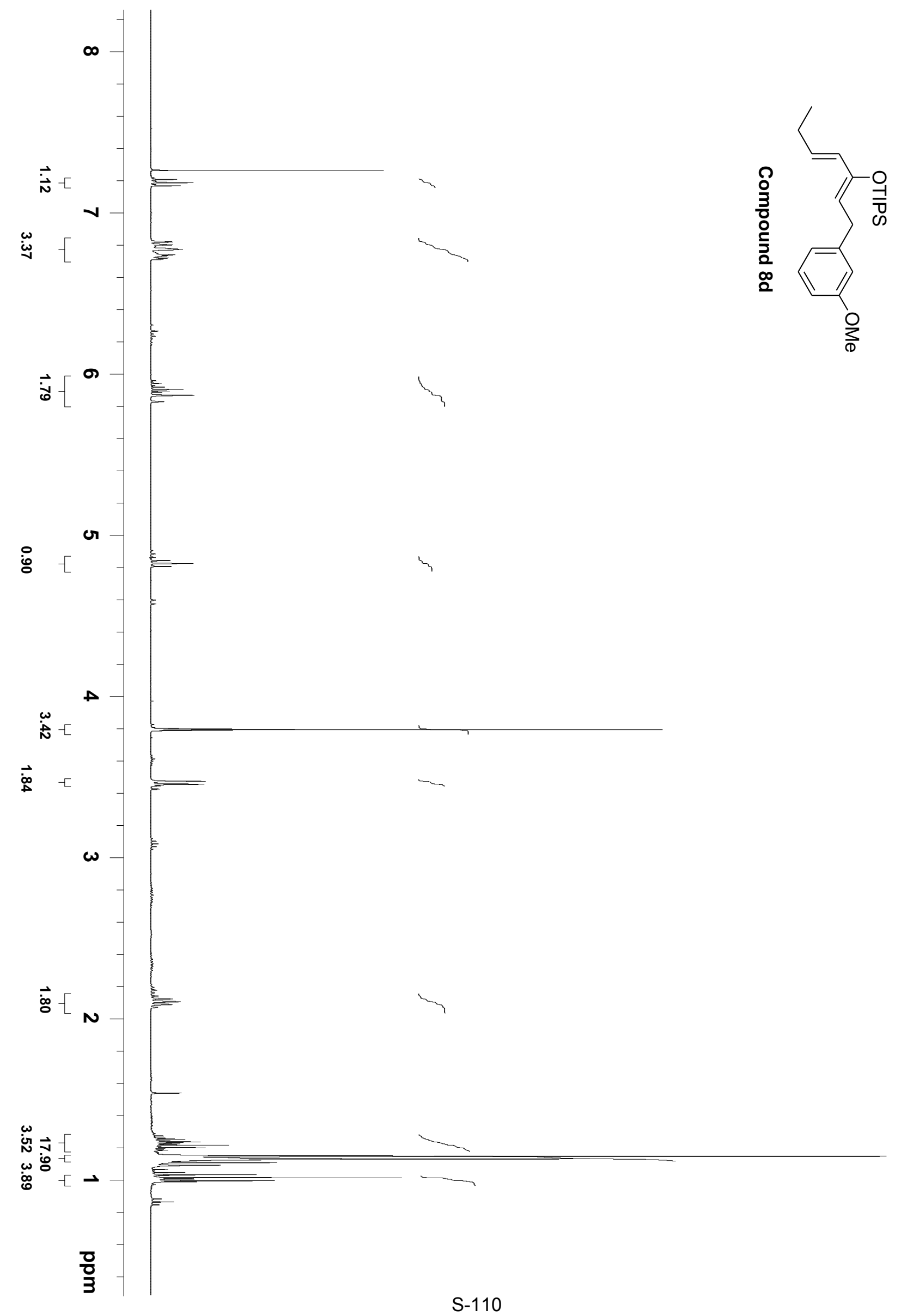


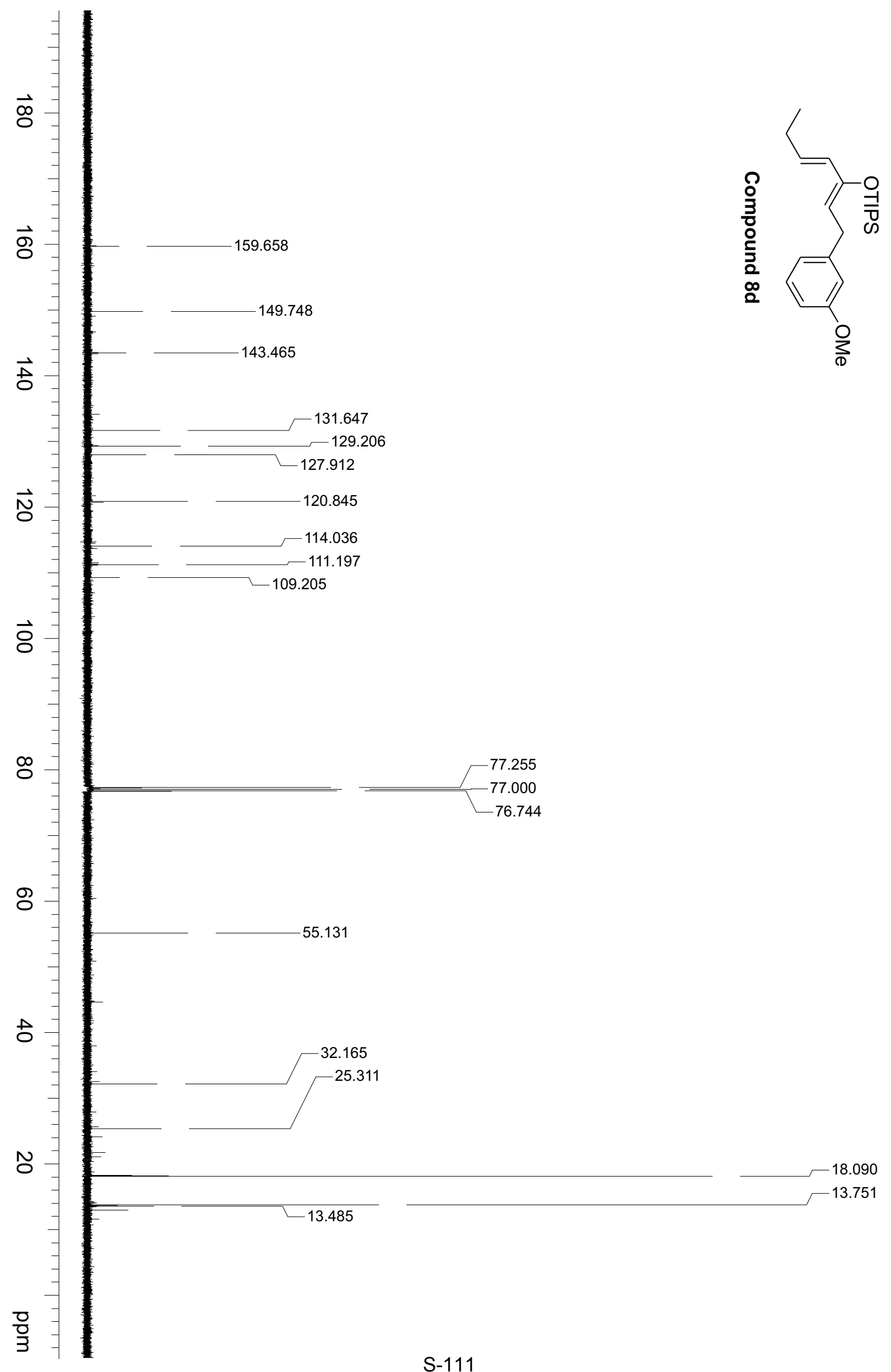




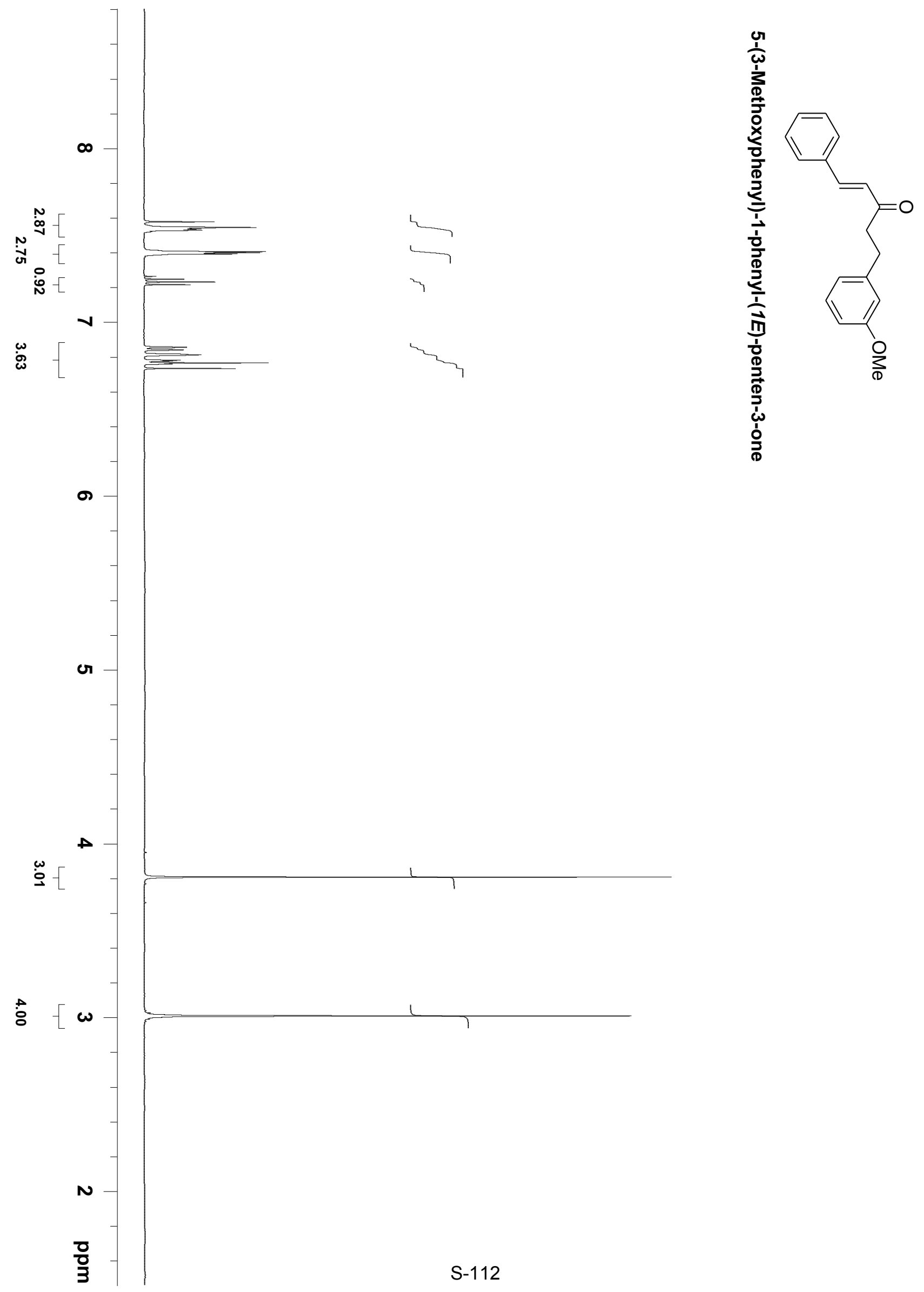




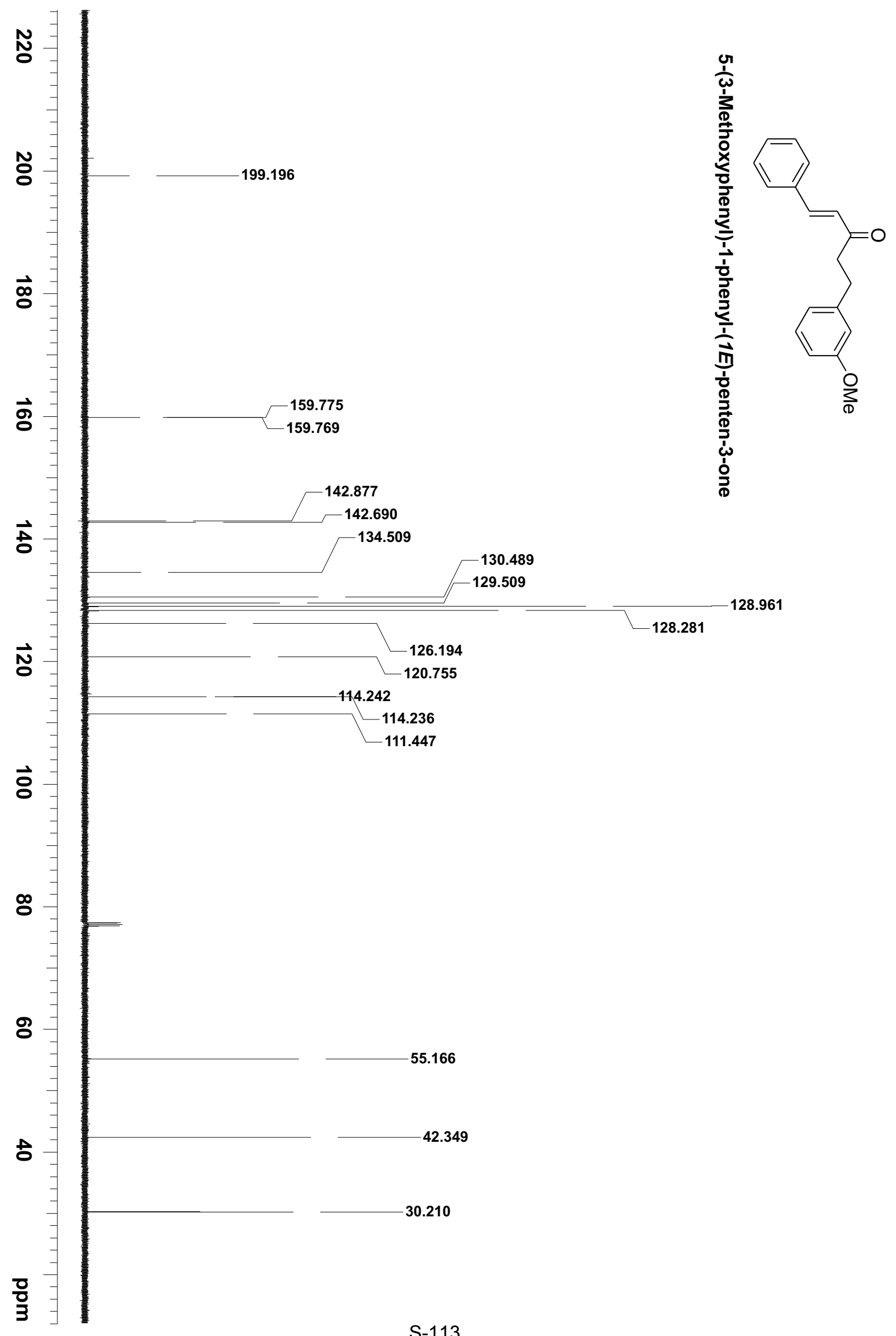




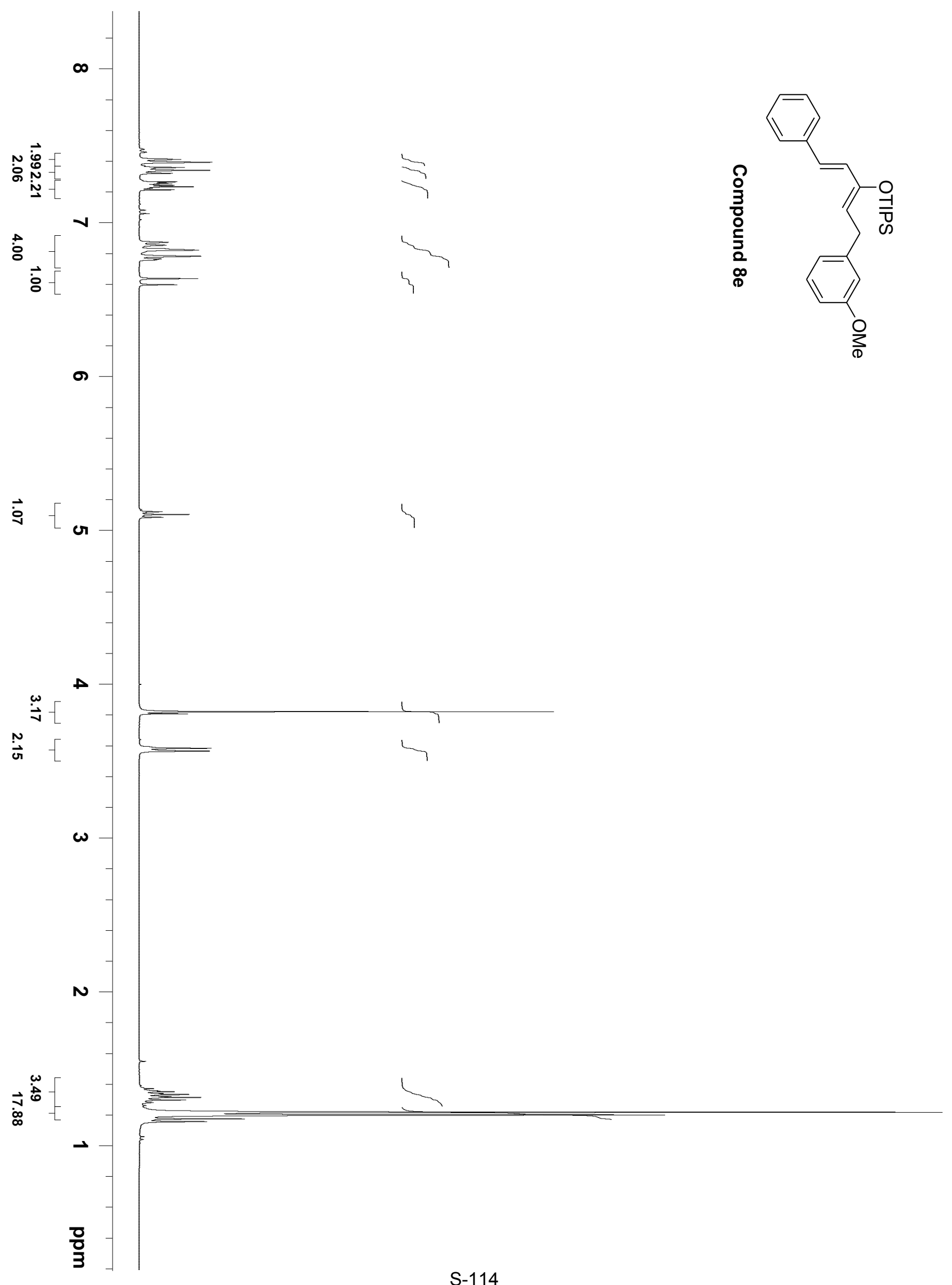




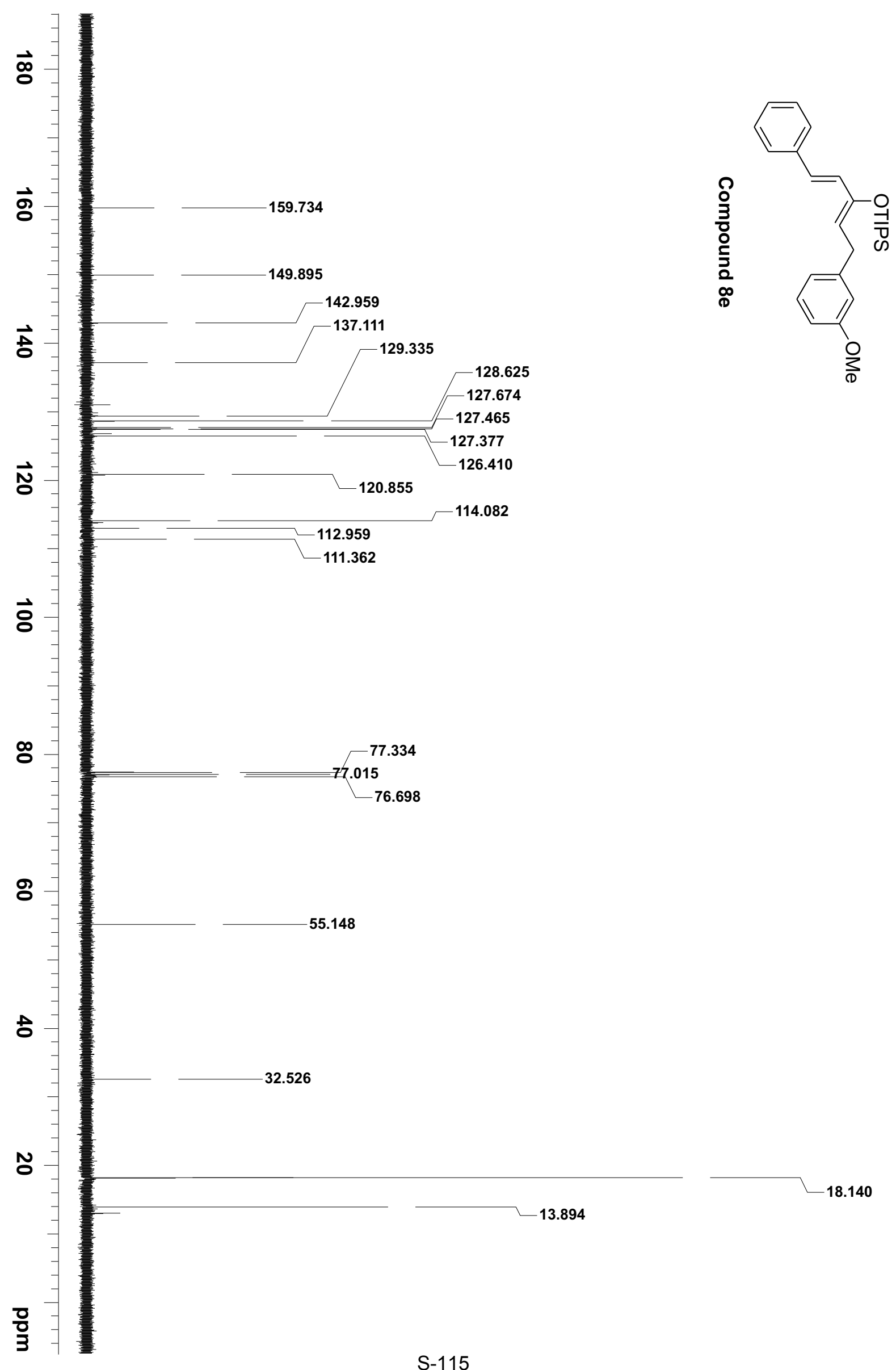




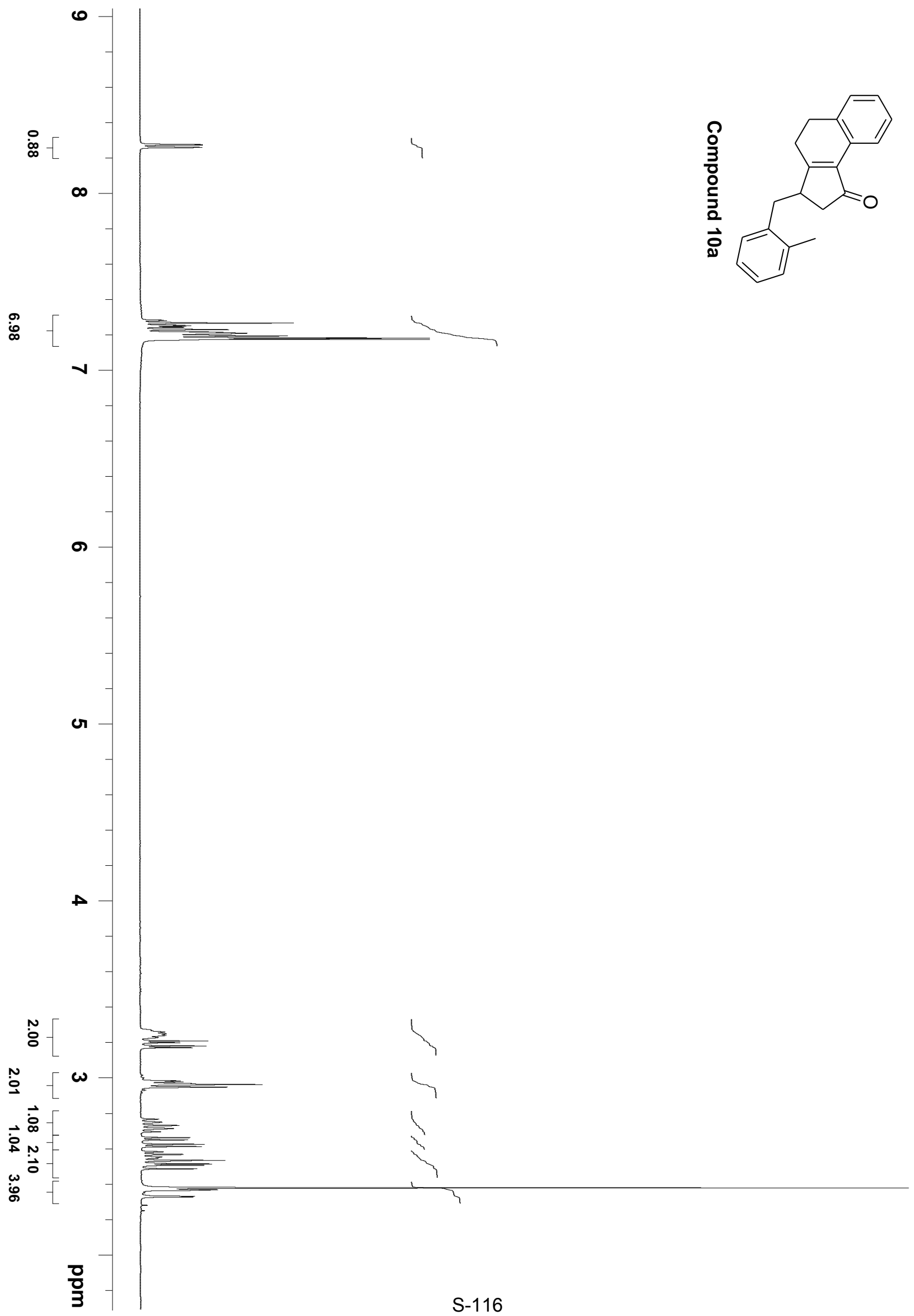




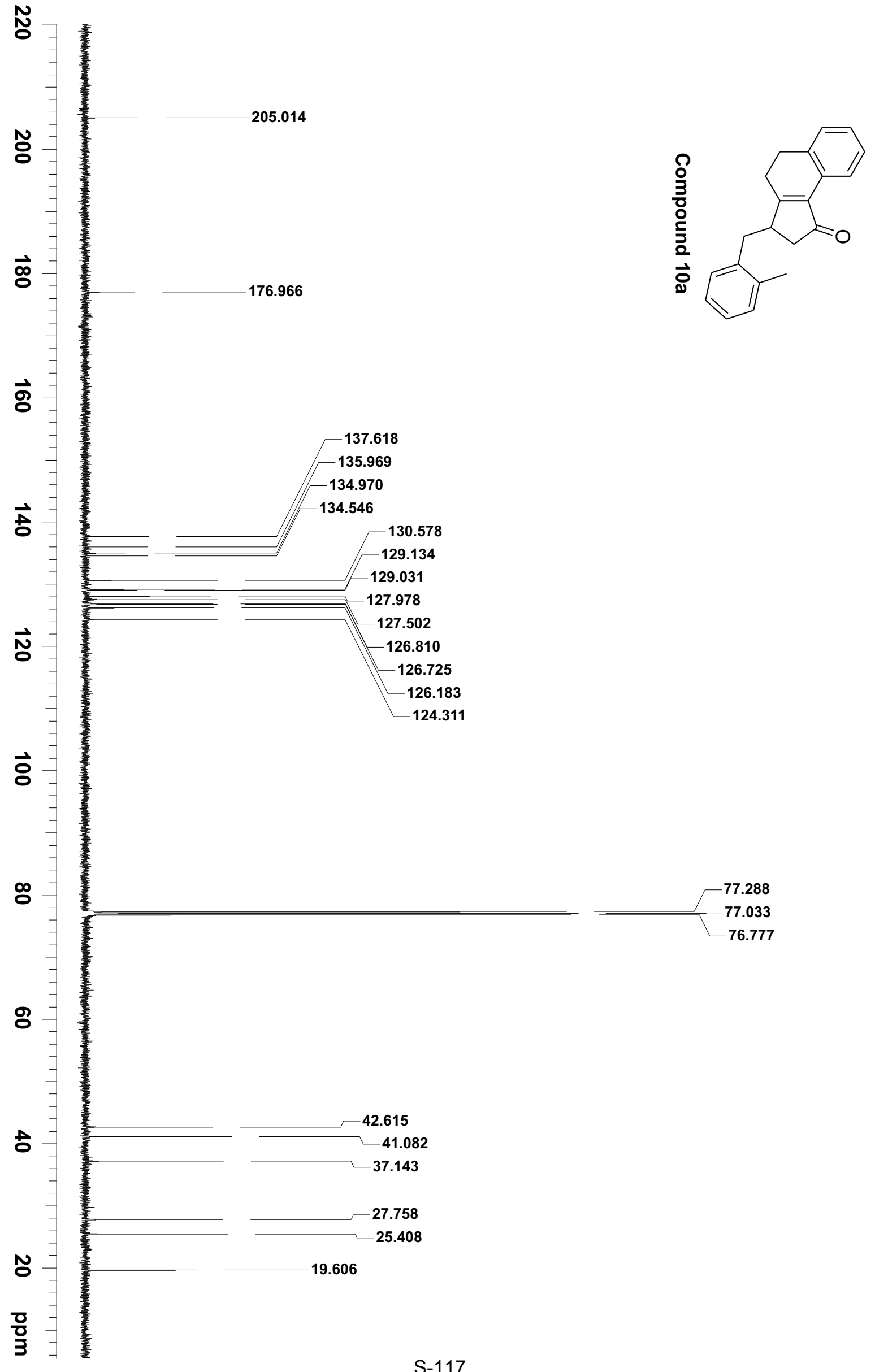




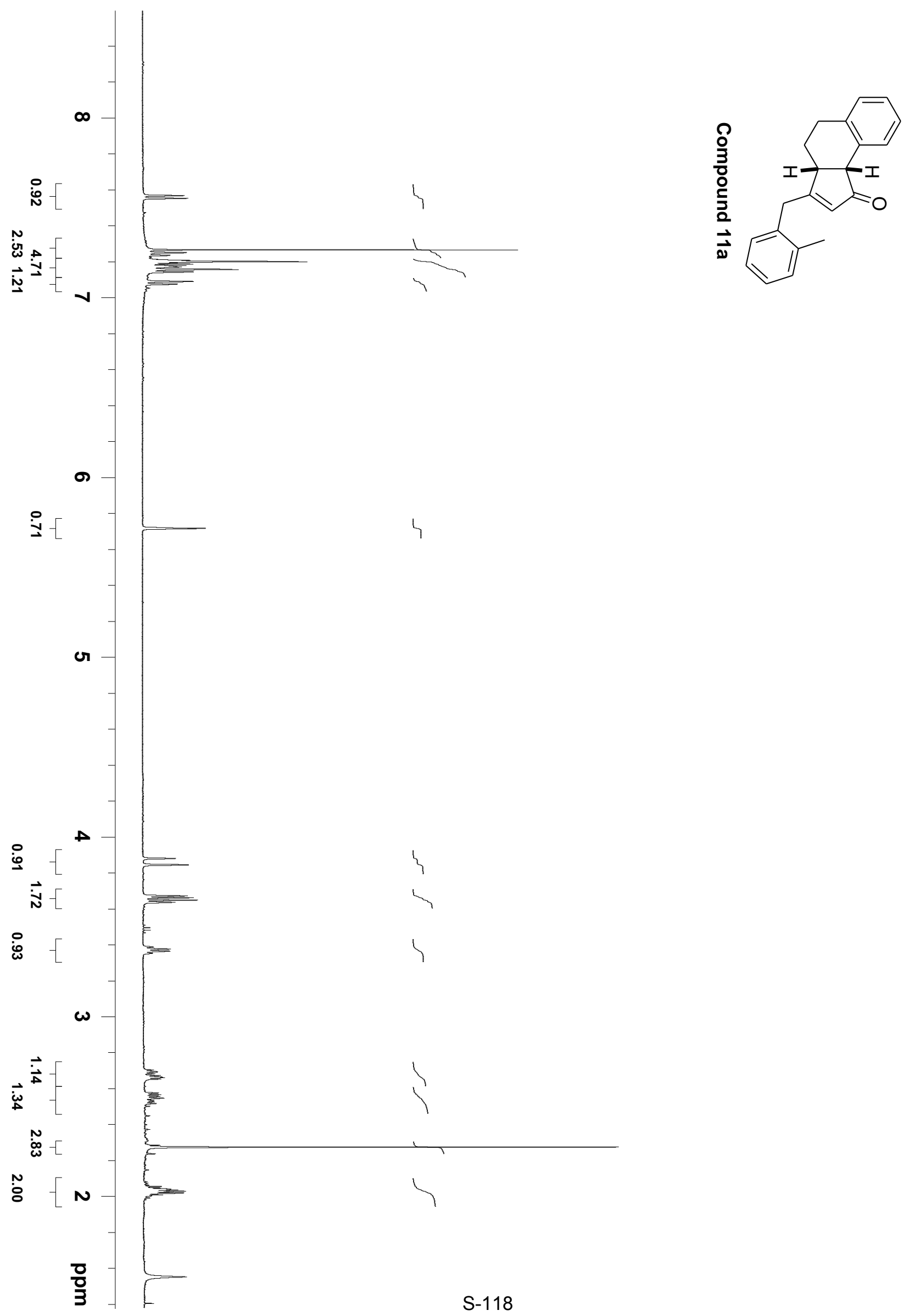




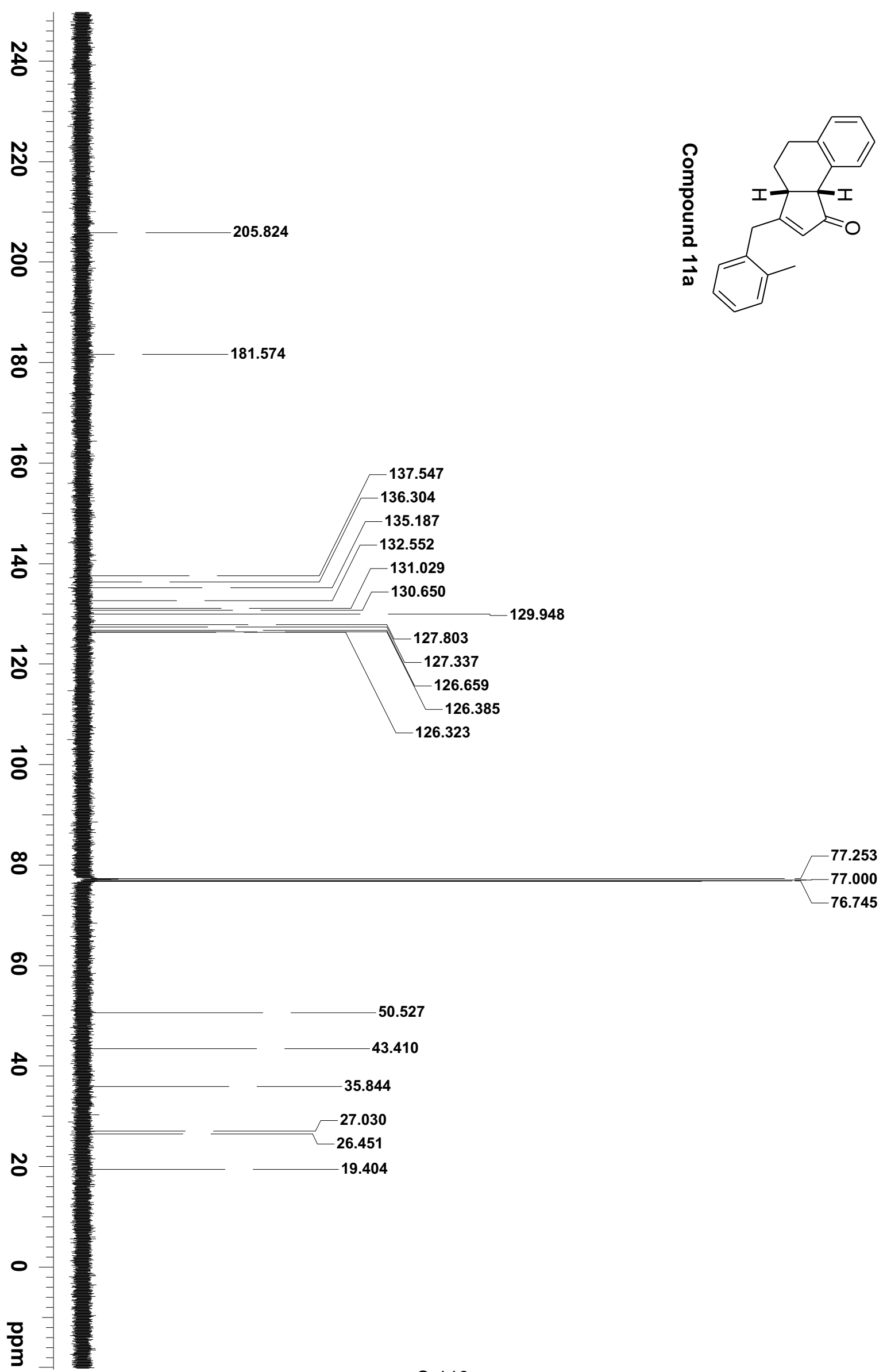




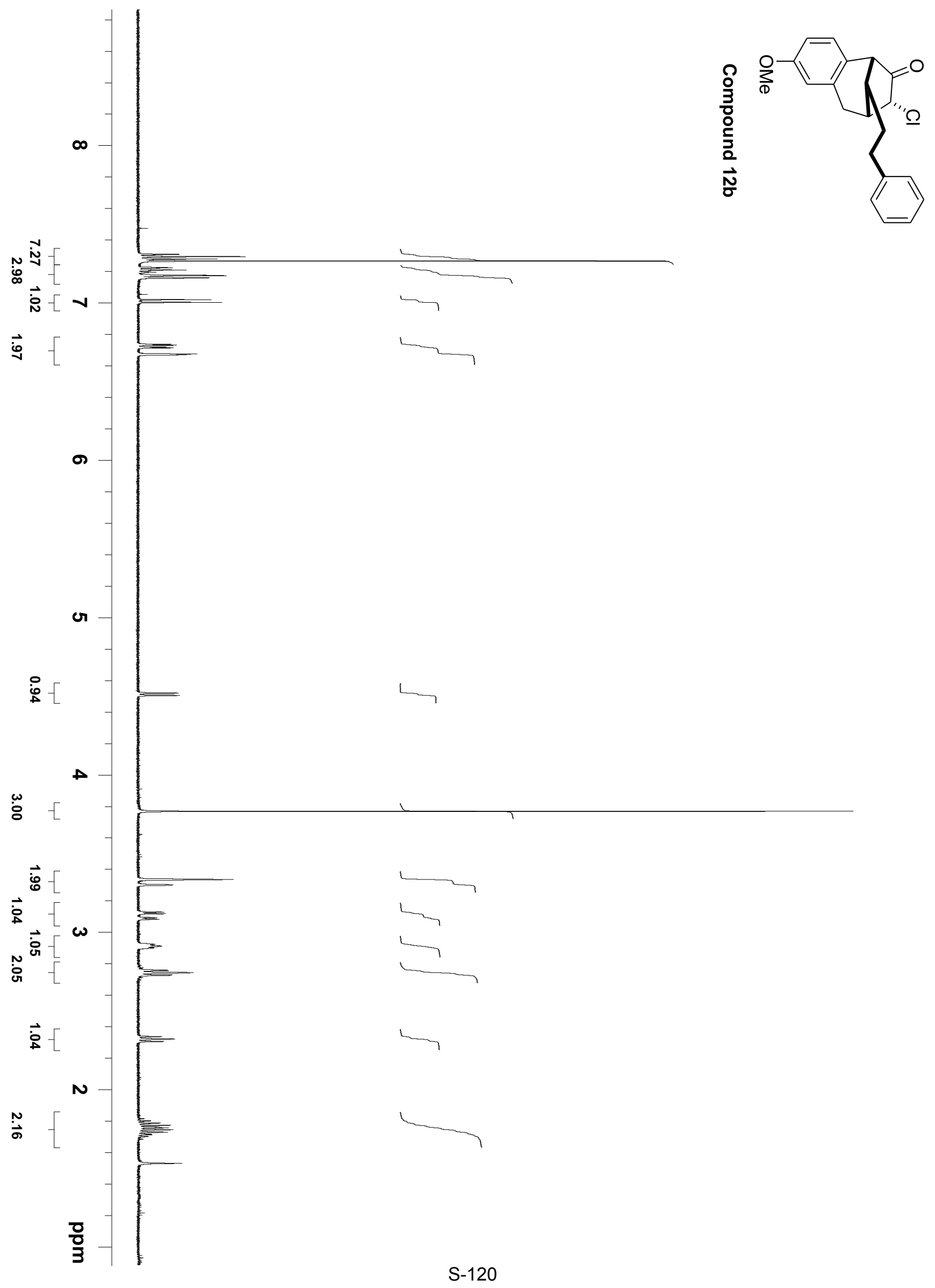




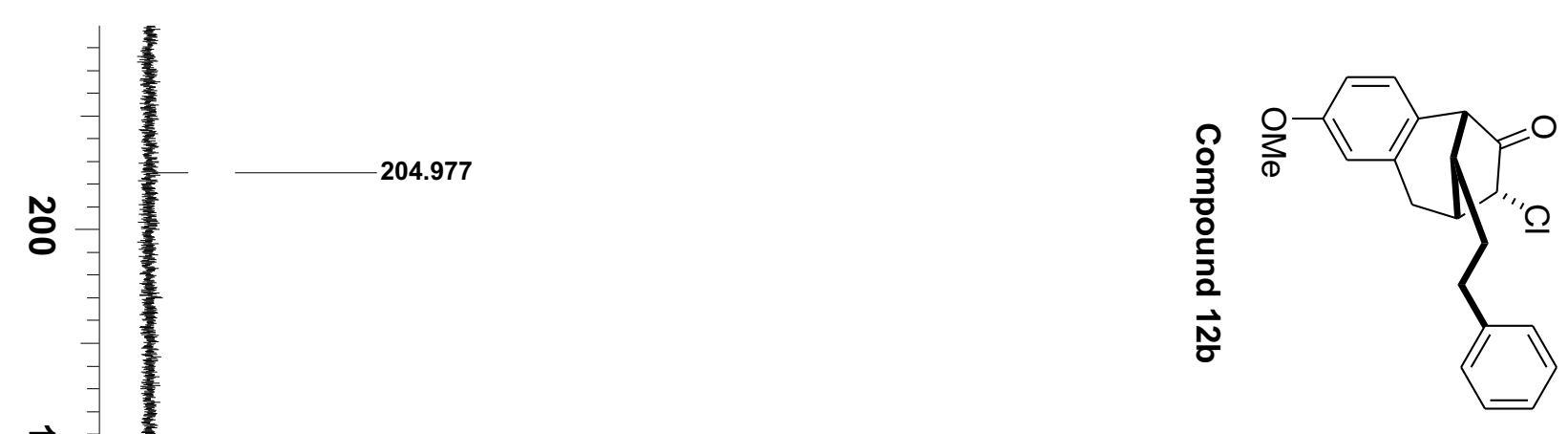

$\vec{\infty}$

$\overrightarrow{8}$ 咅 $\quad 159.532$

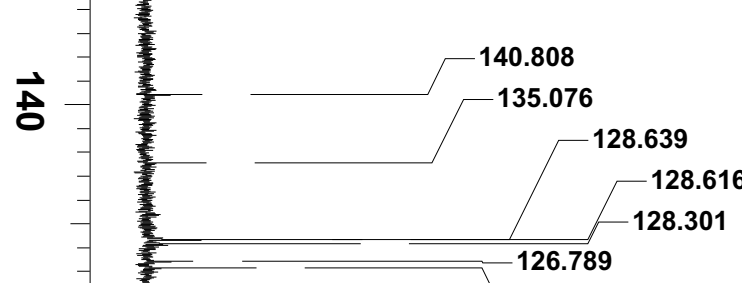

$\overrightarrow{8}$

ஃ

$\overrightarrow{0}$

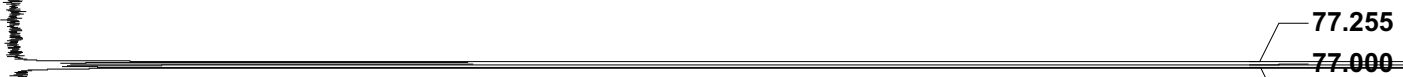

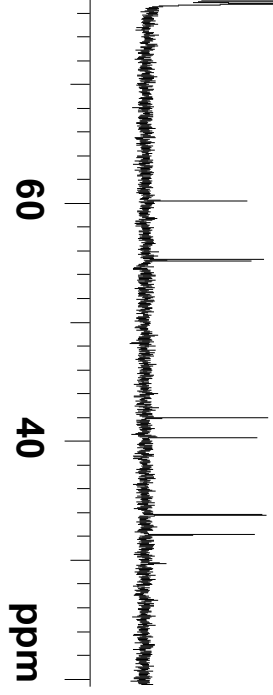

76.745

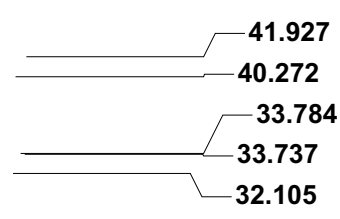




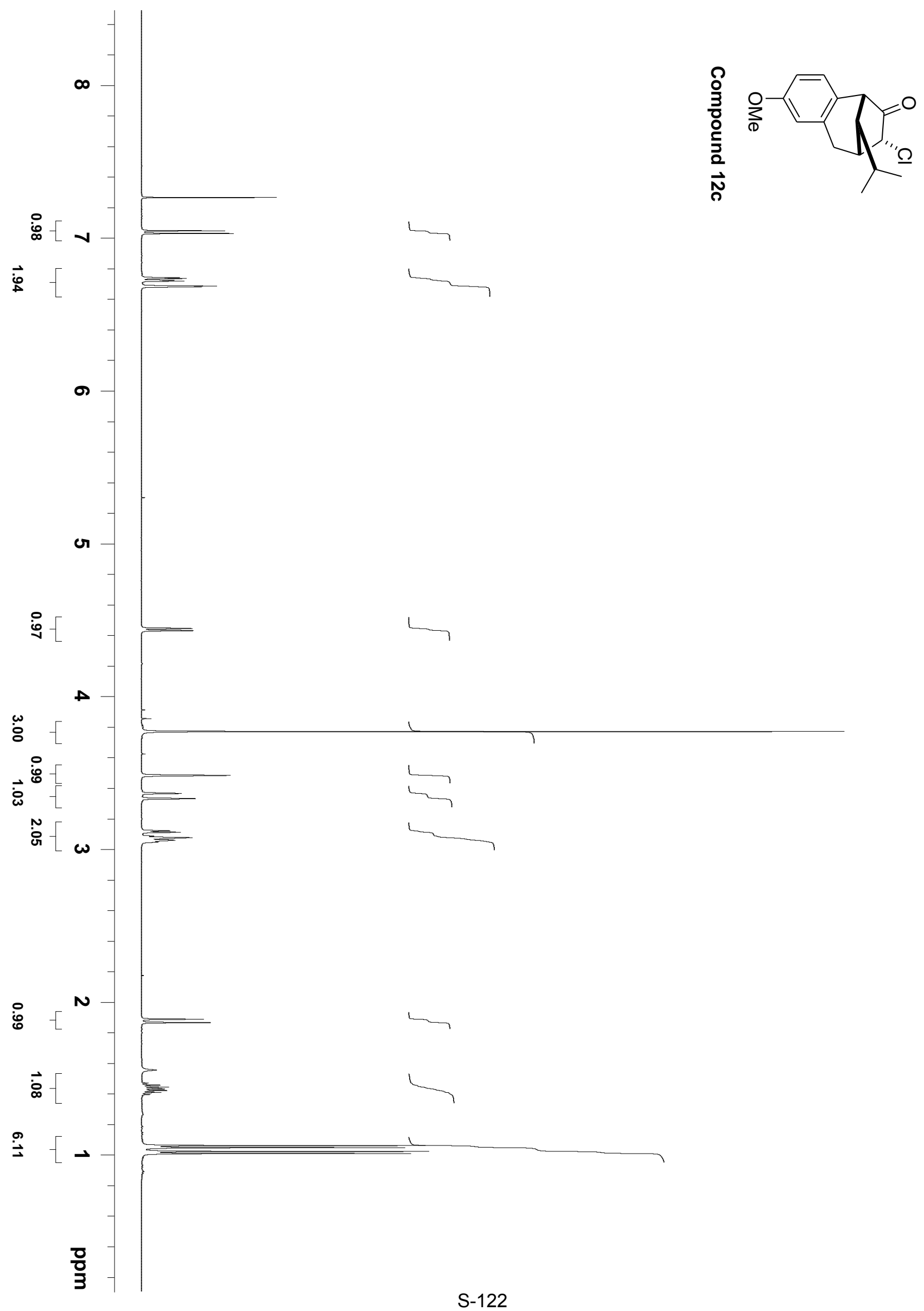




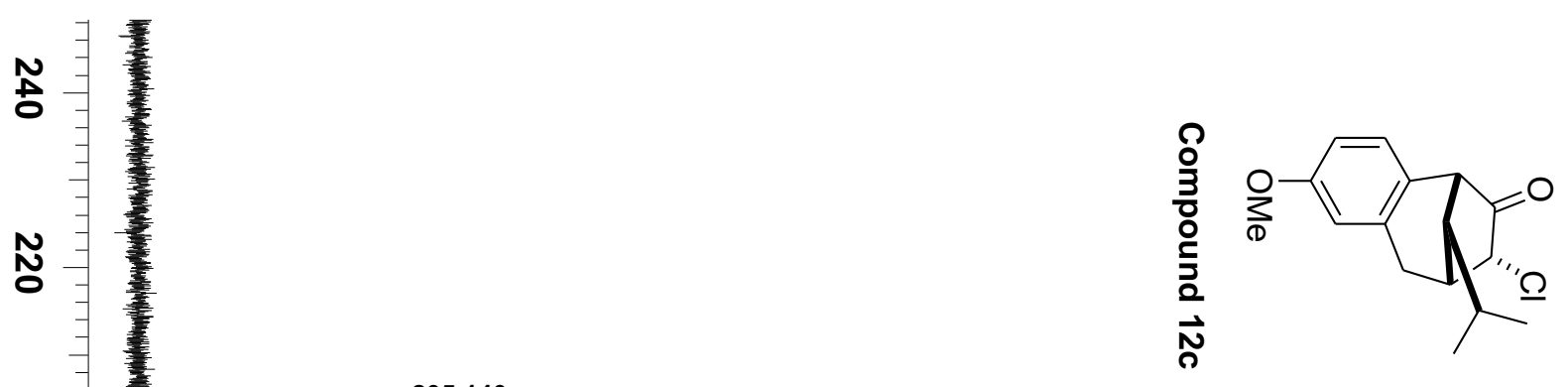

ญ

$\overrightarrow{\mathrm{g}}$

$\vec{\sigma}$

$-159.464$

135.123

$-128.693$

$\overrightarrow{\mathrm{O}}$

$\overrightarrow{0}$

27.101

$-113.810$

$-113.248$

$\overrightarrow{0}$

\&

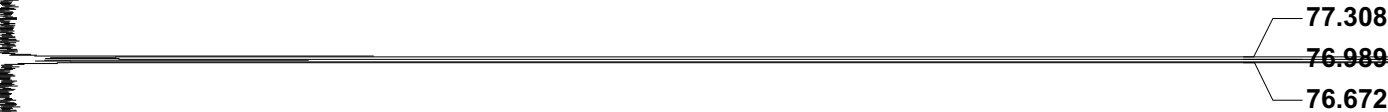

8

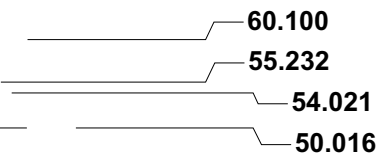

38.083

32.342

28.306

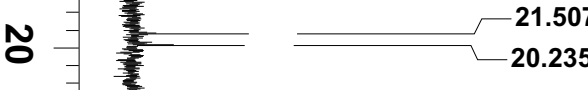

흘 


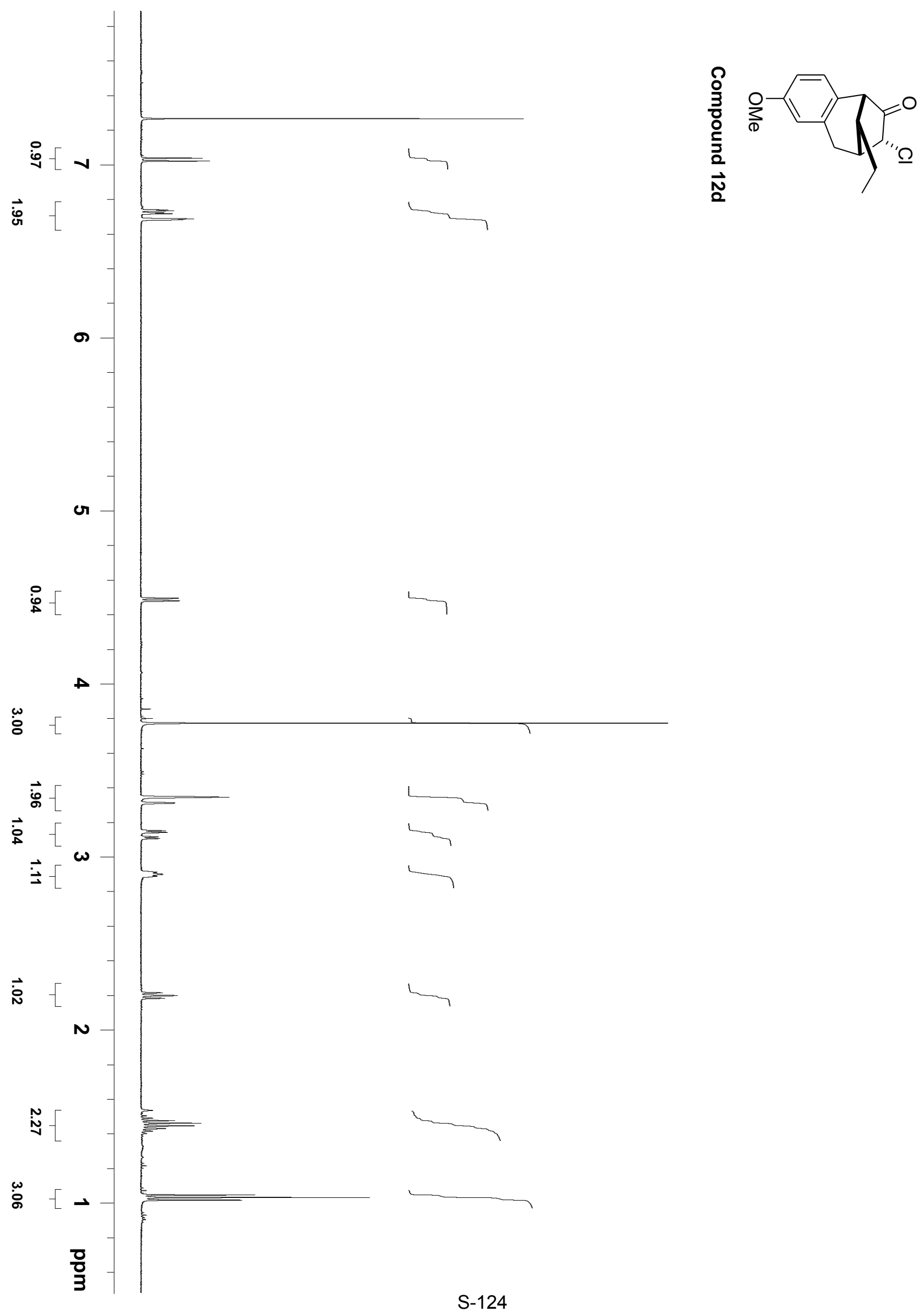



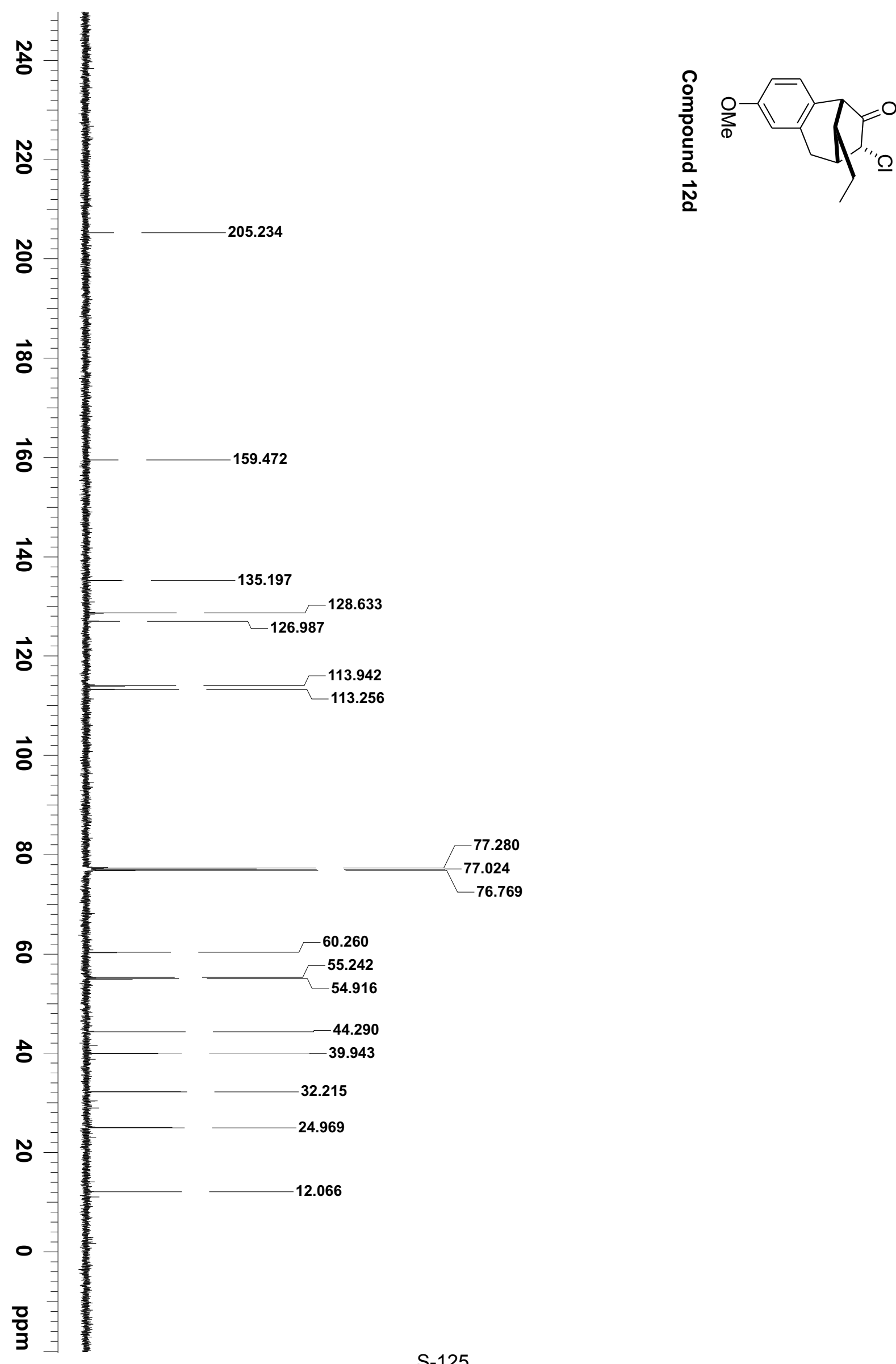


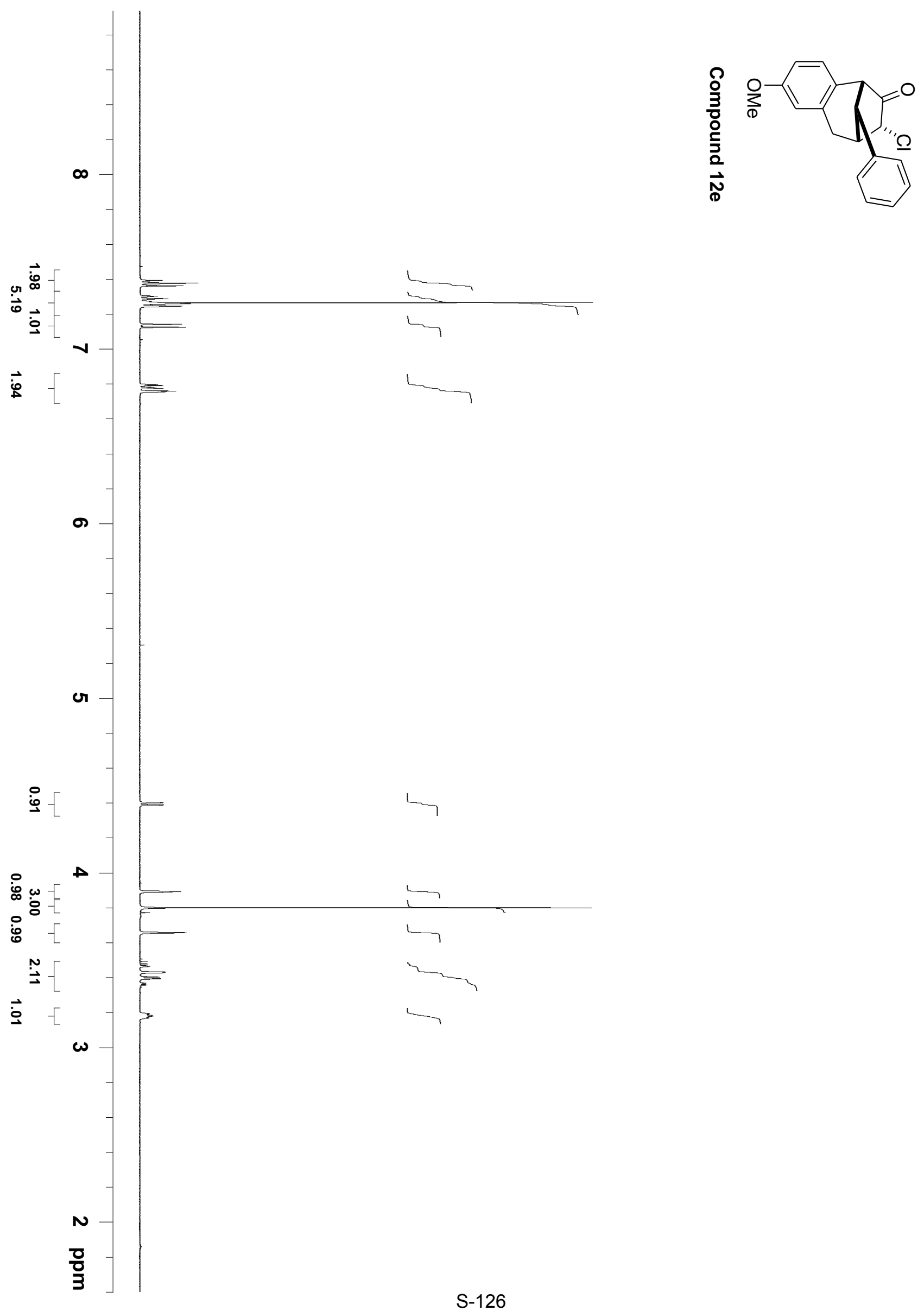




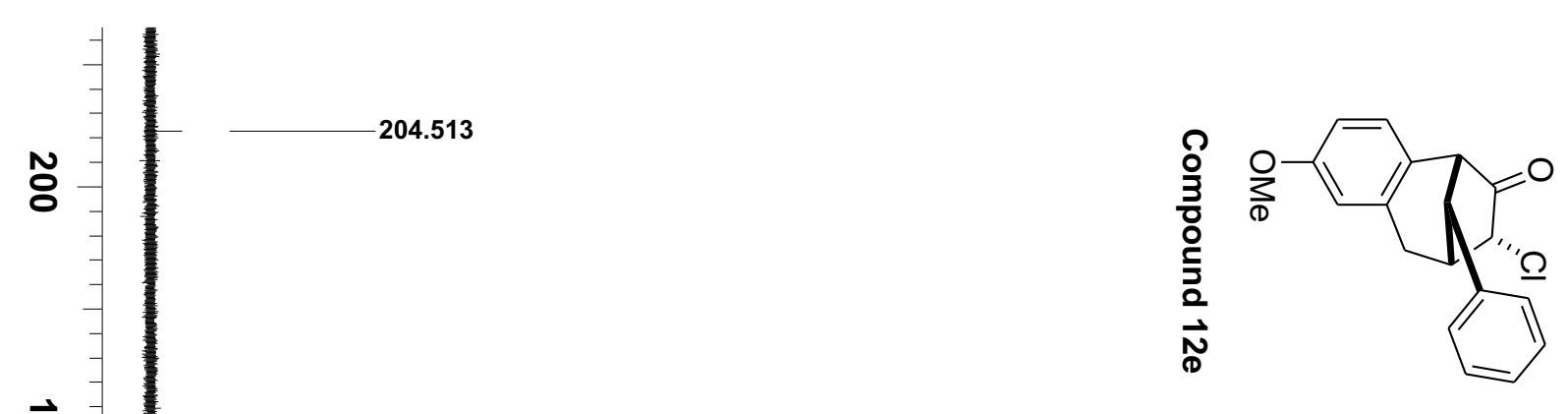

$\vec{\infty}$

$\overrightarrow{8}-159.701$

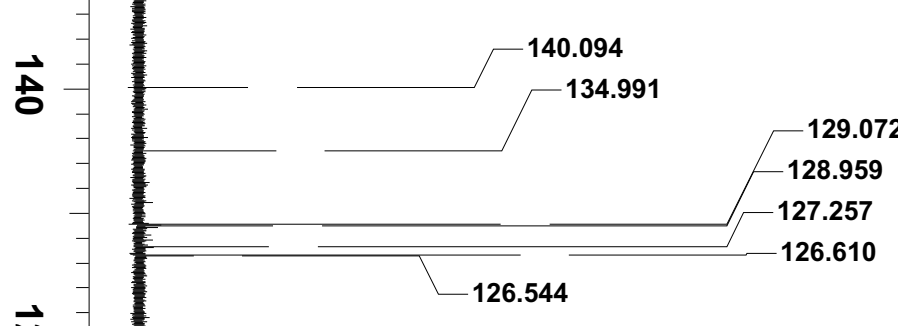

$\overrightarrow{\mathrm{O}}$

$\overrightarrow{8}$

$\infty$

113.981

$-113.620$
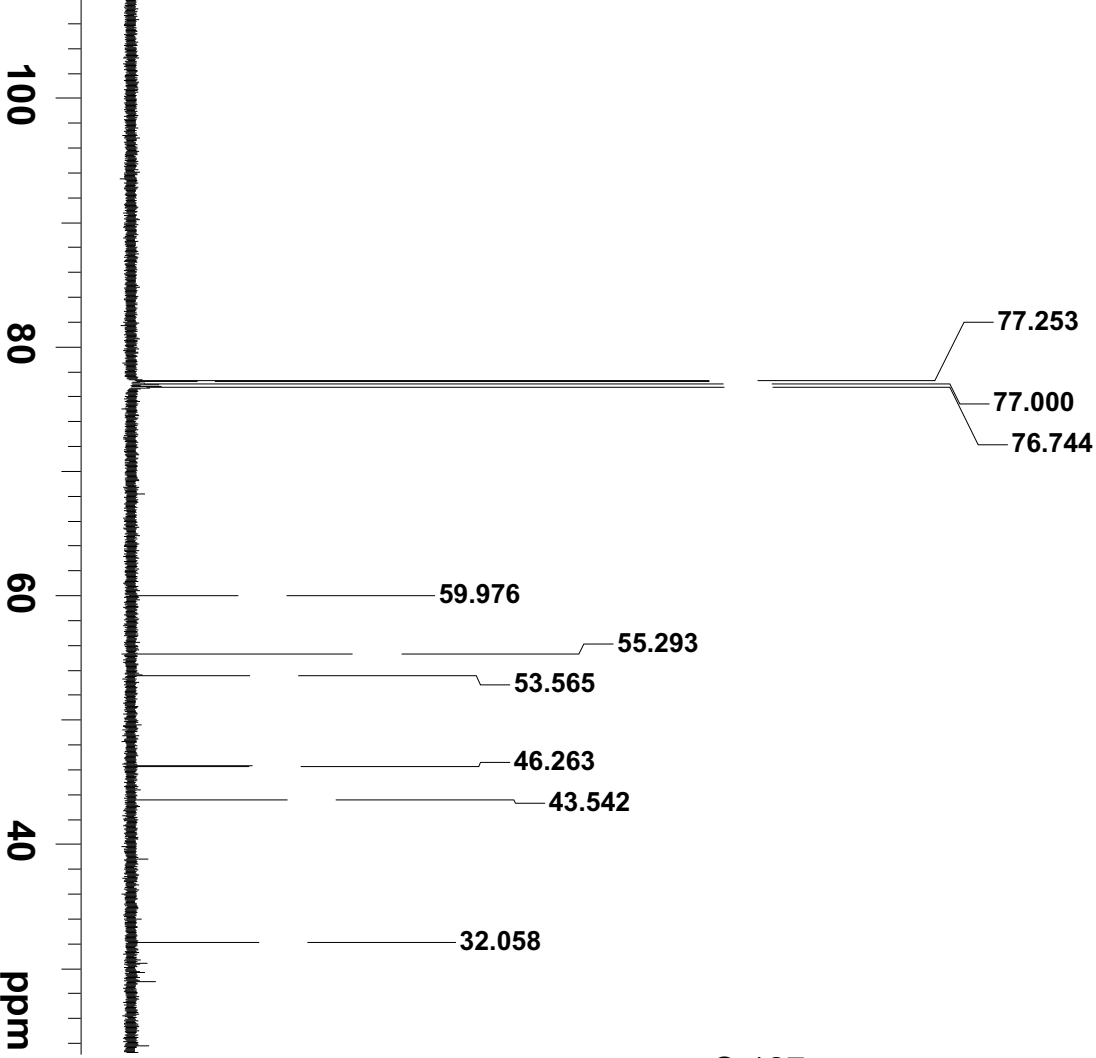